Commission of the European Communities

\author{
energy
}

\title{
GEOTHERMAL HEATING
}

M. AUREILLE

E.D.F.

Direction des études et recherches

Division techniques des énergies nouvelles

Chatou

Contract No. 584-78-7 EGF

1982

EUR 7801 EN 


\section{DISCLAIMER}

This report was prepared as an account of work sponsored by an agency of the United States Government. Neither the United States Government nor any agency Thereof, nor any of their employees, makes any warranty, express or implied, or assumes any legal liability or responsibility for the accuracy, completeness, or usefulness of any information, apparatus, product, or process disclosed, or represents that its use would not infringe privately owned rights. Reference herein to any specific commercial product, process, or service by trade name, trademark, manufacturer, or otherwise does not necessarily constitute or imply its endorsement, recommendation, or favoring by the United States Government or any agency thereof. The views and opinions of authors expressed herein do not necessarily state or reflect those of the United States Government or any agency thereof. 


\section{DISCLAIMER}

Portions of this document may be illegible in electronic image products. Images are produced from the best available original document. 


\section{Published by the COMMISSION OF THE EUROPEAN COMMUNITIES \\ Directorate-General Information Market and Innovation \\ Battiment Jean Monnet \\ LUXEMBOURG}

\section{LEGAL NOTICE}

Neither the Commission of the European Communities nor any person acting on behalf of the Commission is responsible for the use which might be made of the following information 


\section{INTODUTION}

II. DETAILS OF THE COMPUTER PROGRAM 2

2.1. Underlying principle 2

2.2. The basic data 4

2.2.1. Geothermal data 4

2.2.2. Climatic data 4

2.2.3. Operating data 5

2.2.4. Technical data in respect of the equipment 5

2.2.5. Economic data 9

2.2.6. Energy data 12

2.2.7. General data 12

2.3. The circuits used 12

2.3.1. Use of geothermal energy with simple 12 heat transfer

2.3.2. Use of geothermal energy with heat pump 12

2.4. Results of the program 14

III. INFLUENCE OF THE MAIN VARIABLES ON A GEOTHERMAL PROJECT 21

3.I. The boreholes and the network 21

3.1.1. Effect of flow rate and temperature of the geothermal water 21

3.1.2. Importance of pumping 31

3.1 .3 . Chemical constitution of geothermal water 31

3.1.4. Re-injection temperature 33

3.1.5. Networks : : 35

3.2. The centrally situated heating plant 36

3.2.1. Influence of the configuration 36

36 . Influence of the exchanger 36

$\therefore .3$. Heat pumps 37

i:f fwence of conditions of use 47

3.1. Climatic data and free heat 51 
3.3.2. Influence of type of housing on heating requirements

3.3.3. Influence of the temperature of heating systems

3.4. Economic variables

3.4.1. Influence of the cost of materials

3.4.2. Influence of energy costs

3.4.3. Influence of the discount rate and period

IV. SET OF NOMOGRAMS

4.1. Nomograms plotted for dwellings fitted with

$90 / 70^{\circ} \mathrm{C}$ radiators

68

4.1.1. Geothermal heating with heat pump

68

4.1.2. Geothermal heating with simple heat transfer

4.2. Nomograms plotted for dwellings heated by

$55 / 40^{\circ} \mathrm{C}$ underfloor heating systems

4.2.1. Geothermal heating with heat pump

4.2.2. Geothermal heating with simple heat transfer

4.3. Nomograms plotted for dwellings heated by

$70 / 50^{\circ} \mathrm{C}$ radiators

4.3.1 Geothermal heating with heat pump

4.3.2. Geothermal heating with simple heat transfer 


\author{
VI \\ COMMISSION OF THE \\ EUROPEAN COMMUNITIES \\ Directorate-General \\ for Research, Science \\ and Education
}

Geothermal Heating

Part One of the final report (EDF section) - Contract No 584.78.7.E.G.F.

"Analysis of the influence of the main variables and set of nomograms

enabling a rapid assessment to be made of the economic value and

performance of a geothermal heating installation".

\title{
Project Leader:
}

Mr Aureille: Head of Division: New Sources of Energy 
Studies :

$\begin{array}{ll}\text { Mrs Lamethe-Parneix: } \begin{array}{l}\text { Engineer in the Division: ) } \\ \text { New Sources of Energy }\end{array} & \begin{array}{l}\text { ) responsibility } \\ \text { Mechnician in the Division: ) general study } \\ \text { New Sources of Energy }\end{array} \\ \text { Mr Pourbaix: } & \begin{array}{l}\text { Engineer in the Division: } \\ \text { New Sources of Energy; } \\ \end{array} \\ & \text { responsible for the study on heat distribution } \\ & \text { networks. }\end{array}$

EDF

Directorate for Studies and Research

6 quai Watier - 78400 - CHATOU 
XI I / $591 / 81-E N$

NDS/ cW

PART ONE

INTRODUCTION 


\section{I - INTPODUCTION}

The decision to build a geothermal heating plant generally requires the prior knowledge of a number of factors, some of which - such as the characteristics of the geothermal resources - cannot be determined at the time the decision is made. It is therefore very useful to estimate the degree to which a geothermal project can be influenced by the totality of these variables. This problem has necessitated the use of computer programs.

The aim of this study - following a brief reminder of the principle underlying the program (sce paragraph II) - is to demonstrate the influence of the main variables (see paragraph III) and then to supply nomograms from which an initial estimate may be made without having to use data-processing facilities (see paragraph IV) - of the viability of projects in both energy and economic terms.

The studies carried out by F.DF and OET were divided up as follows: EDF concentrated on the effect of the variables on drilling (flow rate and temperature of the geothermal water) and on the network whereas OET concentrated on the effect of climate and the type of housing. As regards the central boiler plant, similar studies have been carried out showing two alternative schemes for the incorporation of heat pumps.

The graphs and nomograms contained in the report have been drawn up by EDF, using the same criteria to describe the housing accomodation and the plan for connecting the heating network to the geothermal resource.

In all cases, the likely influence on the project of all the variables is expressed in terms of energy and economic criteria. 
PART TWO

DETAILS OF THE COMPUTER

PROGRAM

Note to reader:

Explanations of the various data abbreviations used in the report may be found in tables II.11 and II.12 on pages $15 \% 16$ respectively. 


\section{II- DETAILS CONCERNING THE COMPUTER PROGRAM}

\subsection{UNDERLYING PRINCIPLE}

The GEOPAC-EDF-INFRATEL computer program processes data relating to the geothermal project and carries out the thermal and energy calculations relating to the various heating systems which use geothermal energy.

The calculation data are mainly variables whose effect on the viability of the project is described below.

The variables relate to the geothermal resource, climatic data, the premises to be heated, the options available in respect of the centrally-situated heating plant and economic data.

The various stages and operation. of the computer program are diagrammatically represented in the simplified flow chart shown in figure II.1. The annual energy requirements are calculated on the basis of hourly data for the heating season bearing in mind the type and number of housing units and the climate. The calculations relating to thermal factors are then made in respect of the selected configurations for the respective positions of the geothermal exchangers, heat pumps, users and auxiliary boilers. The aggregate amounts of geothermal, electrical and auxiliary energy consumed by the housing units provide the basis for the energy balances for the geothermal heating project where there is either straight heat exchange or exchange via heat pumps and for comparing this system with conventional heating systems. The economic calculations then provide a basis for assessing the value of the project. 


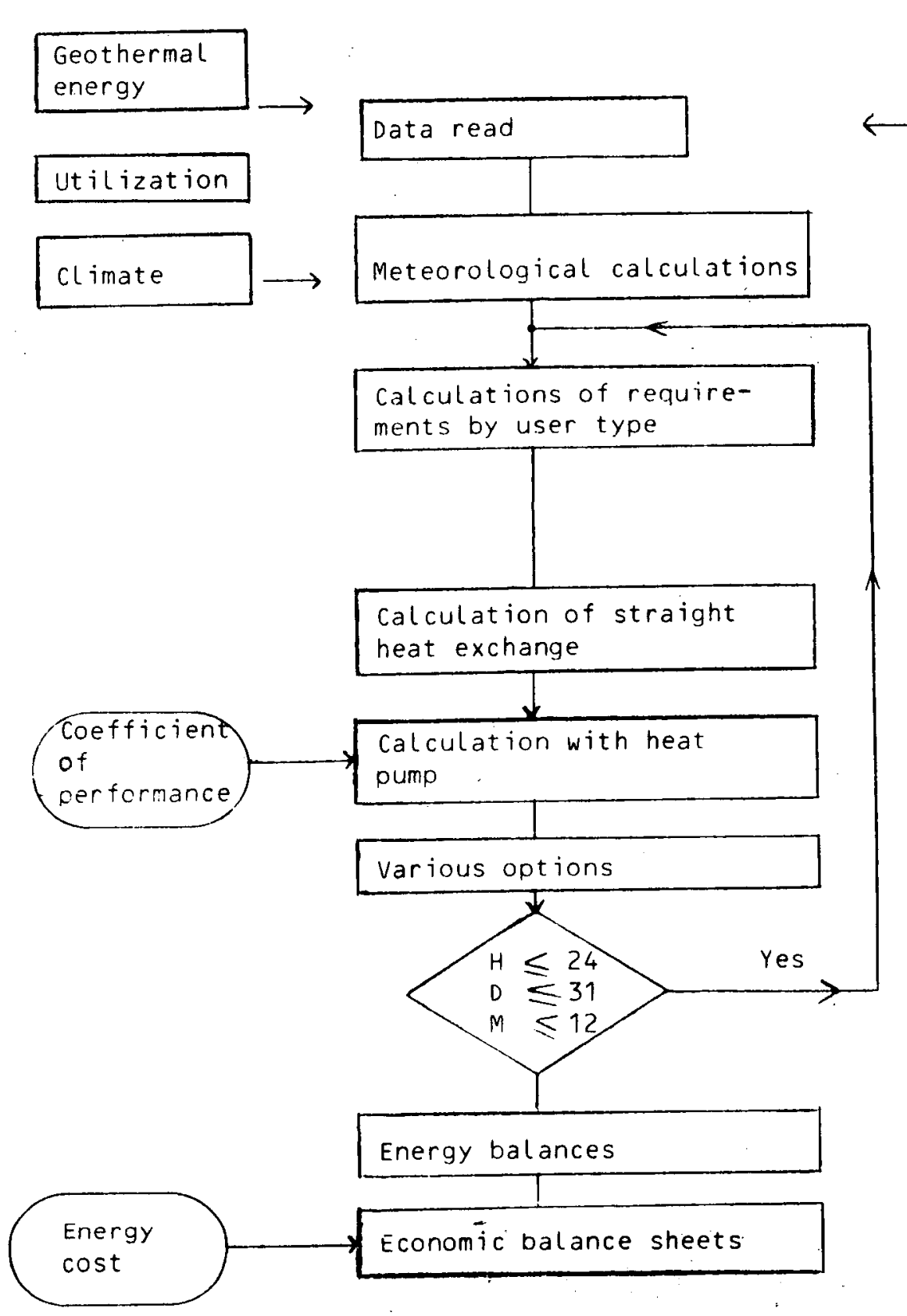

Central

boiler plant

Economic

data

Technical

data
$H$ : hour
$D$ : day
M : month

FIGURE II.1 : SIMPLIFIED FLOW CHART 


\subsection{IHE BASIC DATA}

\subsubsection{Geothermal data}

2.2.I.I. Wateq

In order to cover most eventualities, three values have been used : i.e. $80^{\circ} \mathrm{C}, 60^{\circ} \mathrm{C}$ and $40^{\circ} \mathrm{C}$.

The corresponding borehole depths are approximately $1800 \mathrm{~m}, 1400 \mathrm{~m}$ and $600 \mathrm{~m}$.

2.2.1.2 Geothermal_fl_ow__a

To cover the range of possibilities, three values have been selected : 100, 200 and $300 \mathrm{~m} 3 / \mathrm{hr}$ per extraction borehole. No account has been taken of artesian phenomena.

\subsubsection{Number_of boreholes}

It has been agreed to use the same number of injection boreholes as extraction boreholes.

\subsubsection{Chemical_constitution_of the_water} Except for the study on the effect of the chemical properties of the water, the water is assumed to be corrosive and to require the use of titanium exchangers.

\subsubsection{Climatic data}

The values used to obtain the results published in this report are the minimum and maximum daily outside air temperatures recorded at orly during the heating period from 15 October 1976 to 20 May 1977.

This corresponds to a "cont inental"-type climate; the effect of climate (oceanic, mediterranean etc.) has been investigated by OET and will be dealt with in a separate report which will also discuss the effect of the type of housing. 


\subsubsection{Operating data}

2.2.3.1. Number_of_dwel_Ling

In order to plot the curves, different numbers of dwellings have been considered : i.e. $2000,2500,3000,4000,4500$ and 5000 .

2.2.3.2. Average volume This was fixed at $186 \mathrm{~m} 3$.

2.2.3.3. Coefficient_of median heat_loss This was fixed at $1.05 \mathrm{~W} / \mathrm{m} 3 .{ }^{\circ} \mathrm{C}$.

\subsubsection{Iemeeratures_of thef the heating systems}

Three types of heating unit were considered, i.e.

- radiators whose inlet-outlet temperatures are $90^{\circ} \mathrm{C}$ and $70^{\circ} \mathrm{C}$ respectively;

- Low temperature radiators, $70 / 50^{\circ} \mathrm{C}$;

- underfloor heating, $55 / 40^{\circ} \mathrm{C}$.

As far as the EDF part of the report is concerned, the temperature settings up to $18^{\circ} \mathrm{C}-$ which are determined as a function of the external temperature - lie on straight lines (see figures II..2, II.3).

The detailed study of internal systems carried out by $O E T$ is not included in this report.

\subsubsection{Technical data in respect of the equipment}

2.2.4.1. Drilling pumps. The electrical power ratings used (extraction and injection pumps) are as follows :

- $150 \mathrm{~kW}$ at $100 \mathrm{~m}^{3} / \mathrm{hr}$

- $200 \mathrm{~kW}$ at $200 \mathrm{~m}^{3} / \mathrm{hr}$

- $325 \mathrm{~kW}$ at $300 \mathrm{~m}^{3} \cdot / \mathrm{hr}$ 


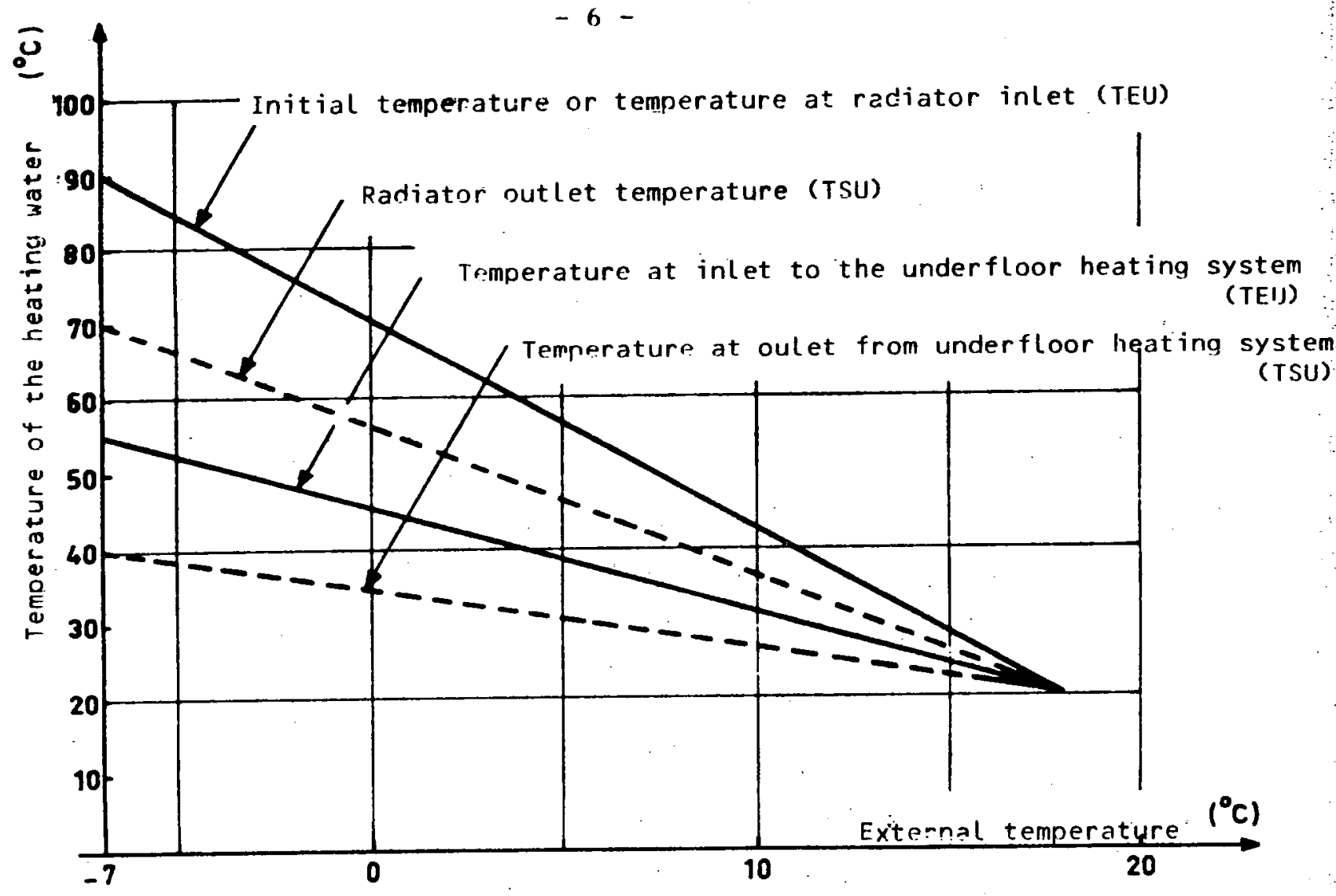

FIGURE II. 2 : SETTING CHARACTERISTICS OF THE $90 / 70^{\circ} \mathrm{C}$ RADIATORS AND THE $55 / 40^{\circ} \mathrm{C}$ UNUERFLOOR HEATING SYSTEM

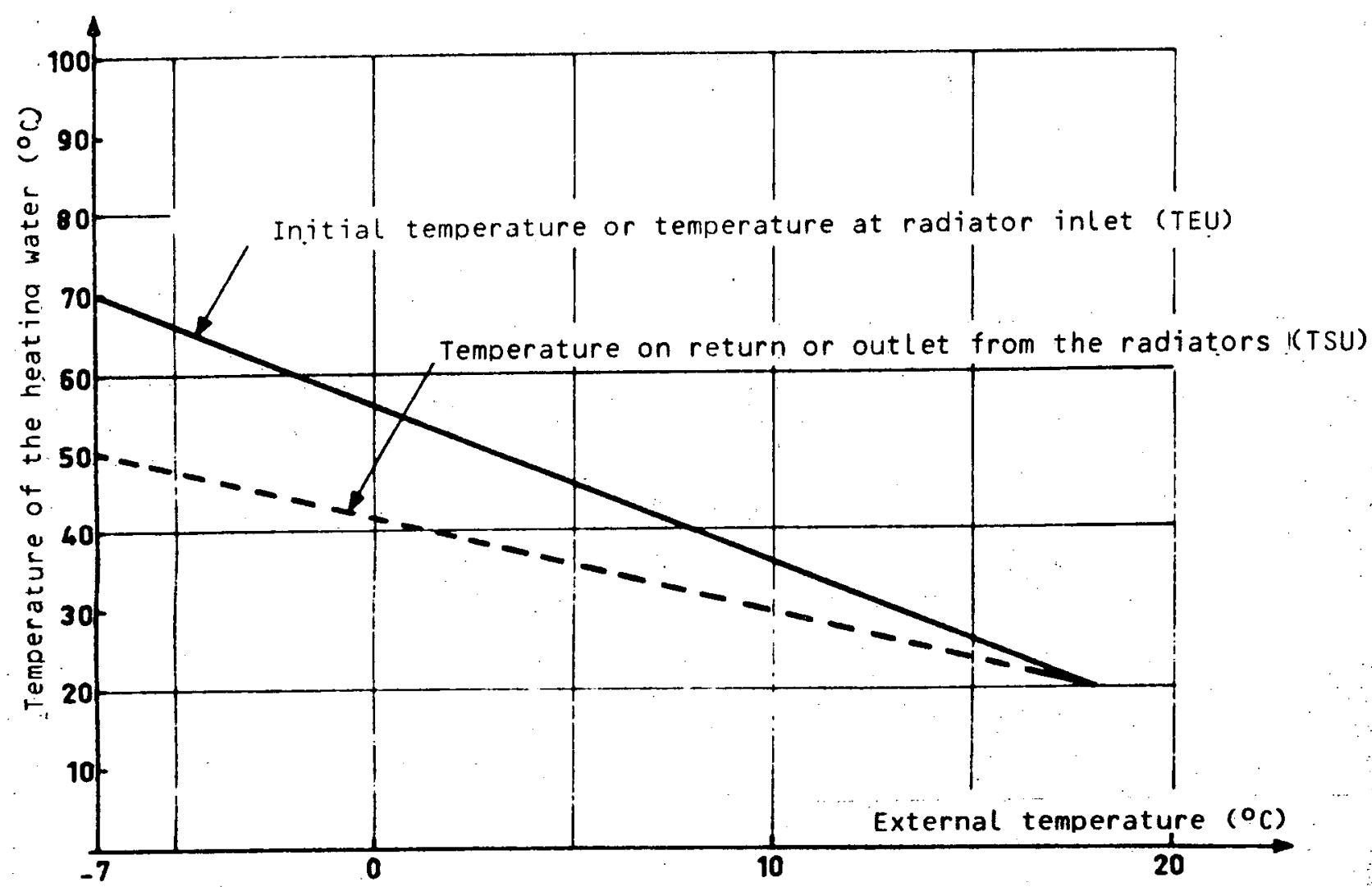

FIGURE I1.3: SETTIMG CHARACTERISTICS OF LOW-TEMPERATURE PADIATORS $\left(70 / 50^{\circ} \mathrm{C}\right)$. 


\subsubsection{Auxiliary_pumes}

The electrical power of the auxiliary pumps varies as a function of the flow-rate of the heat-carrying fluid in the system. It is defined by the following expression :

AuX (in kW) $=0.077 Q\left(M^{3} / h r\right)+2.5$

(see Figure II.4.)

\subsubsection{Heat_exchanger}

This is composed of a number of heat-transfer units - fixed at 5 except in the paragraph describing the effect of this parameter.

\subsubsection{Heat_eume}

The electrical power has been optimized in each of the cases investigated in such a way as to obtain the lowest possible discounted cost per useful thermie:

i) the maximum permissible temperature at the condenser outlet was set at $85^{\circ} \mathrm{C}$,

ii) the average temperature difference between the water and the coolant (in the condenser and in the evaporator) has been estimated at $4^{\circ} \mathrm{C}$,

iij) the minimum permissible temperature difference between the condenser outlet and the evaporator outlet is $18^{\circ} \mathrm{C}$.

iv) the minimum temperature of the water at the evaporator out let is $5^{\circ} \mathrm{C}$,

v) the minimum operating load on the heat pump is $10 \%$ of the nominal value,

vi) the ratio of the coefficient of practical performance to the coefficient of theoretical performance as a function of load has been defined on the basis of the following graph, drawn up from measurements taken at an existing plant (see figure II.5). 


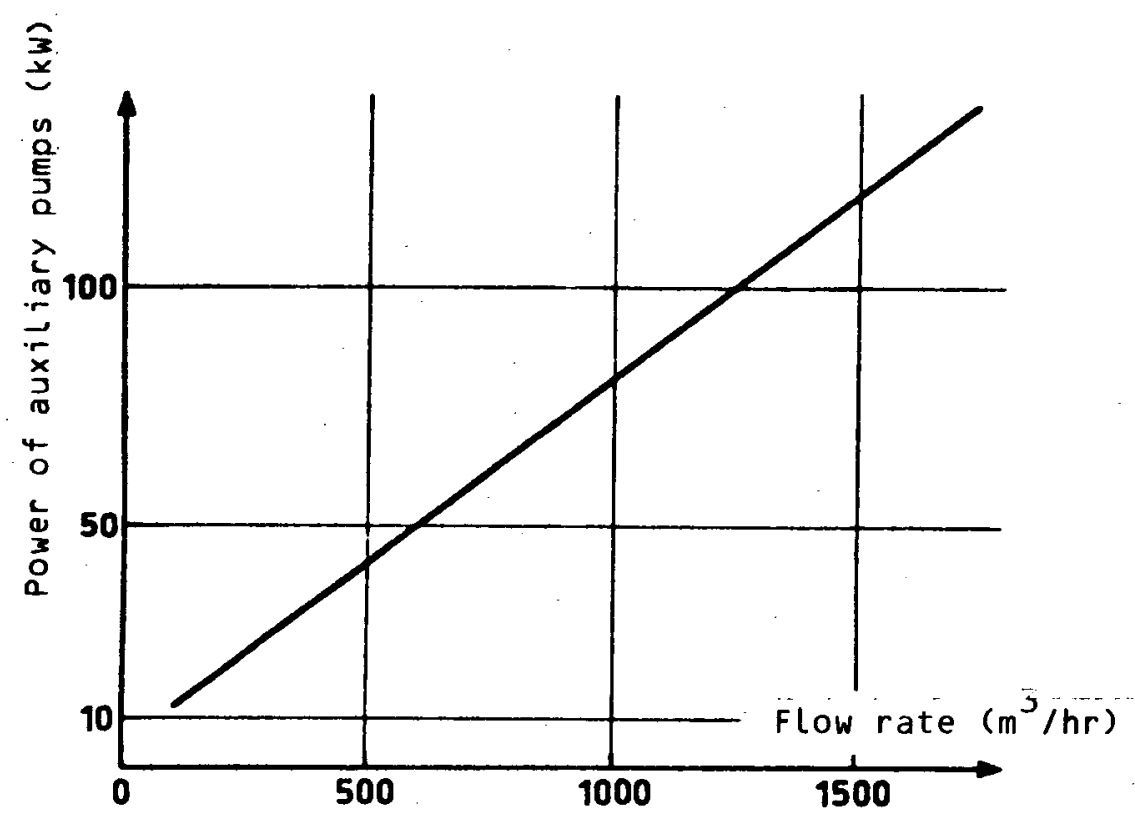

FIGURE II.4 : GRAPH SHOWING THE POWER OF THE AUXILIARY PUMPS

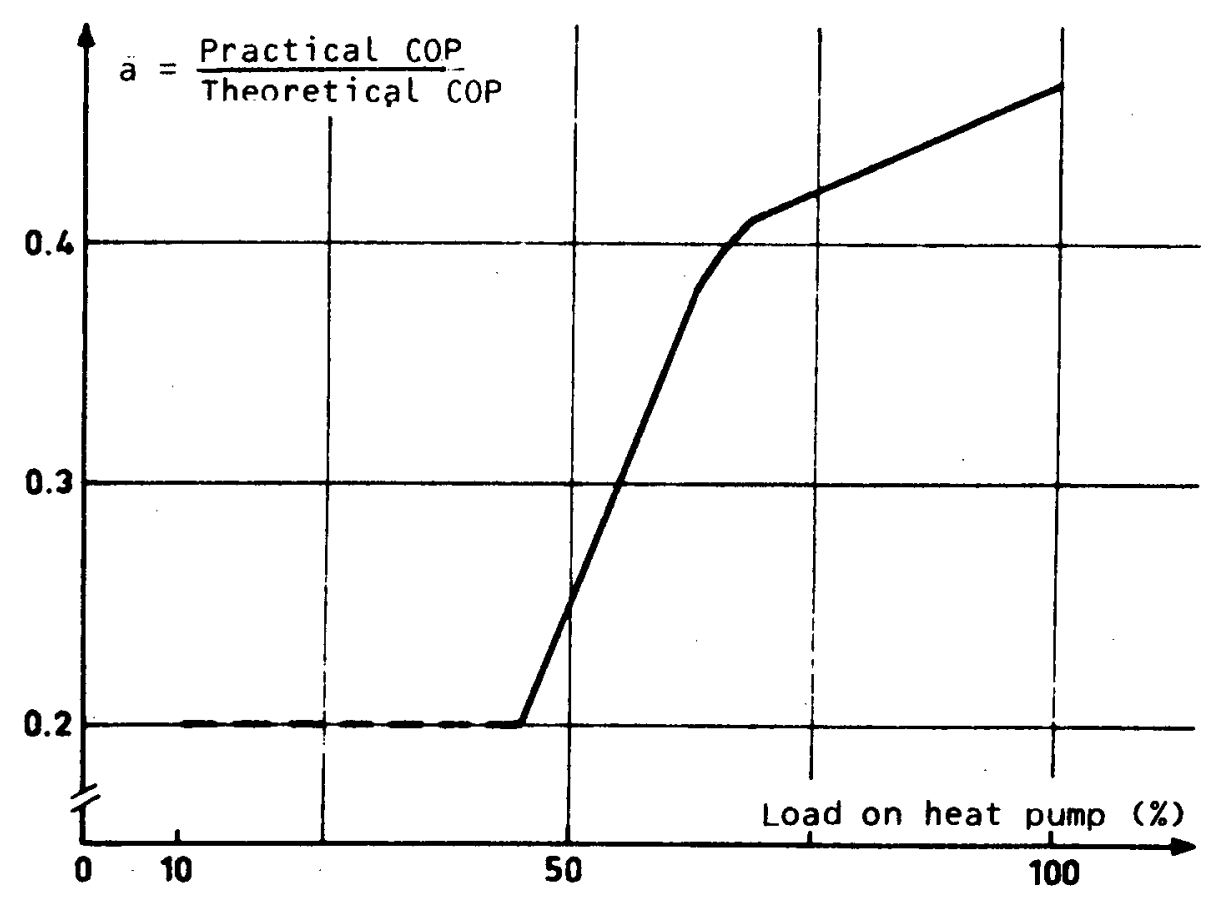

FIGURE II.5: VARIATION IN THE CURVE $a=f(L O A D)$ 


\subsubsection{Economic data valid for (June 1979)}

\subsubsection{Cost_of conventional reference fuel}

This has been fixed at FF 100 kth at the boiler out let.

\subsubsection{Cost_of drilling}

This cost varies with depth or with the temperature of the geothermal fluid. The cost pattern adopted is shown diagrammatically in Figure II.6. It has been based on information supplied by Gaz de France and the Bureau de Recherches Géologiques et Minières to which has been added a $\mathrm{flat}$ rate amount of FF 2.5 million to cover the cost of surface equipment and the network using the geothermal fluid.

FIGURE II.6.: COST OF A PAIR OF BOREHOLES AS A FUNCTION OF DEPTH

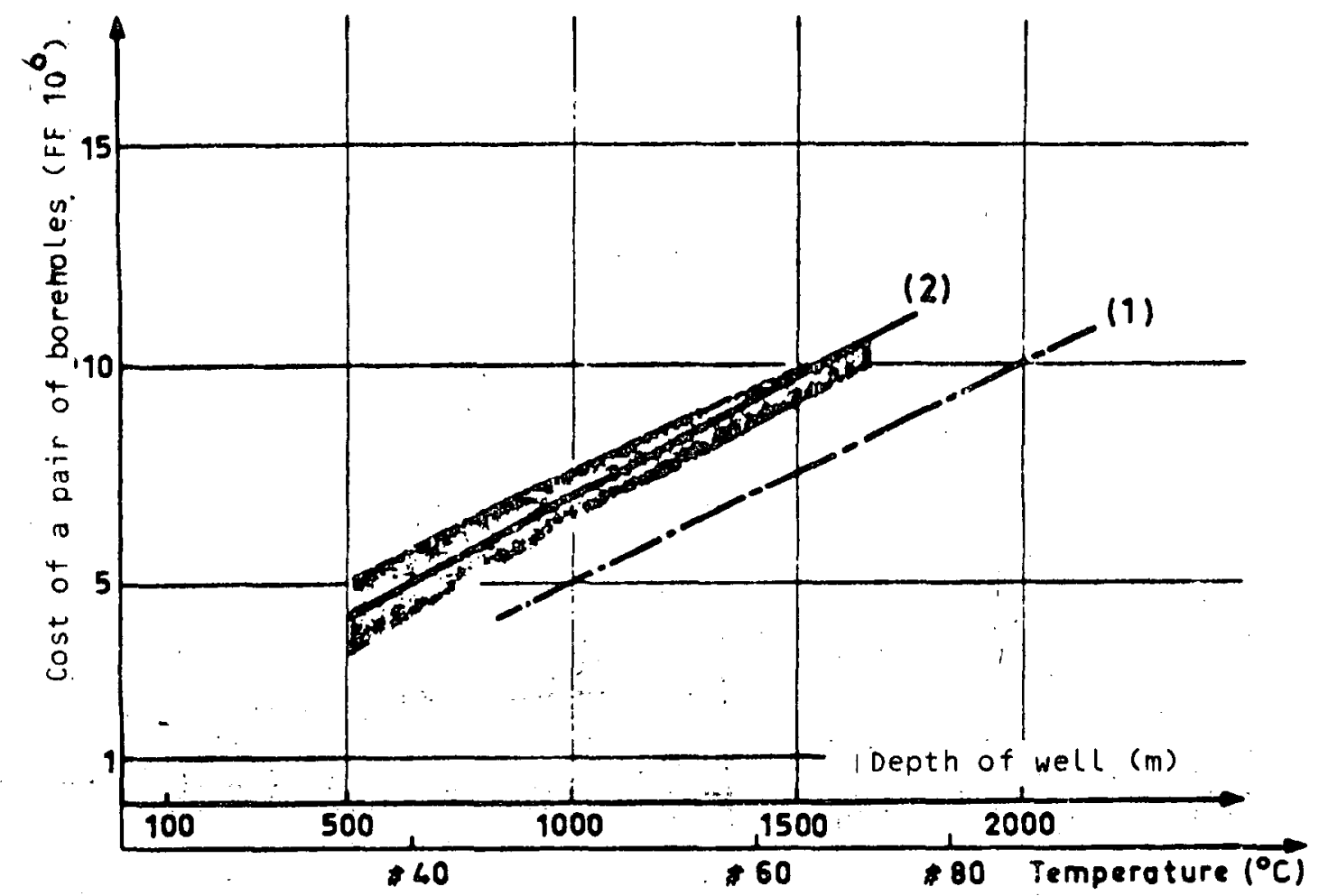

(1) Average estimate. (drilling only) according to data supplied by the BRGM and GDF.

(2) Estimate (including surface equipment). 


\subsubsection{Cost__of the he_heat_exchanger}

This cost is proportional to the heat transfer coefficient $k$ and to the surface area $S$ of the exchanger, i.e.:

Cost in FF $=700.000 \times \mathrm{KS}$ where $\mathrm{KS}$ is expressed in $\mathrm{Gcal} /{ }^{\circ} \mathrm{C}$.

To this must be added the cost of additional equipment, i.e. : $500(Q P+Q S)$ where $Q P$ and QS are the flow rates in the primary and secondary circuits of the exchanger expressed in $\mathrm{m} 3 / \mathrm{hr}$.

\subsubsection{Cost_of the heat_pume}

This cost has been calculated on the basis of the following curve (see Figure II.7) which has been obtained by interpolating data from several manufacturers. If the temperature at the condenser outlet ( TC max) is greater than $50^{\circ} \mathrm{C}$, then the price of the pump is as follows : $(0.0125$ TC $\max +0.375) \mathrm{P}_{1} \times \mathrm{P}_{N^{\prime}}$ where $\mathrm{P}_{N}$ is the maximum heat capacity of the pump.

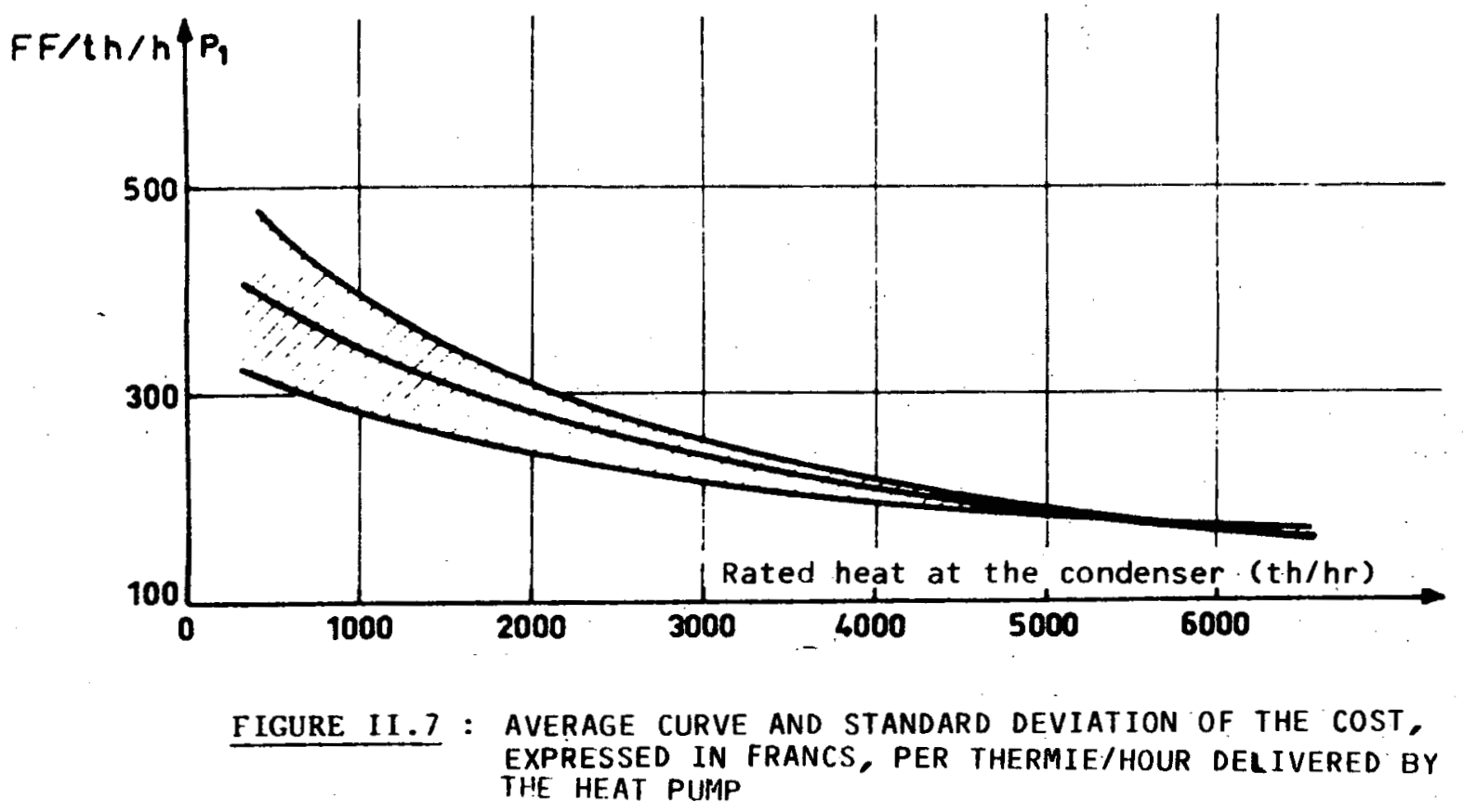


2.2.5.5. Cost_of the fossil fuel_boiler

This cost is proportional to the maximum power,

$P$, which - when expressed in French Francs - is :

cost of the boiler $=300000 \times P$

where $P$ is in thermie/hour.

2.2.5.6. Cost of connection to the grid cof modification to the heating $\mathrm{t}$ ants and of the reguisite civit engineering work.

These costs have been excluded from the calculations in view of their likely fluctuations, and also because each case is specific and must be considered separately.

2.2.5.7. Cost_of electricity

This has been calculated on the basis of the

EDF's green tariff as valid for May 1979

\begin{tabular}{|c|c|c|c|c|c|c|}
\hline \multirow{3}{*}{ Tariff } & \multirow{3}{*}{$\begin{array}{c}\text { Fixed } \\
\text { annual } \\
\text { premium } \\
\text { Basic rate } \\
\text { (francs } \\
\text { per kW) }\end{array}$} & \multicolumn{5}{|c|}{$\begin{array}{l}\text { Energy prices } \\
\text { (centimes per kWh) }\end{array}$} \\
\hline & & \multicolumn{3}{|c|}{ winter } & \multicolumn{2}{|c|}{ Summer } \\
\hline & & Peak & $\begin{array}{l}\text { Normal } \\
\text { full } \\
\text { demand }\end{array}$ & off-peak & $\begin{array}{l}\text { Normal } \\
\text { full } \\
\text { demand }\end{array}$ & off-peak \\
\hline $\begin{array}{l}\text { Long period } \\
\text { off-take }\end{array}$ & 399.09 & 17.87 & 13.70 & 9.05 & 9.80 & 8.78 \\
\hline Auxiliary & 232.03 & 26.22 & 18.43 & 9.61 & 12.67 & 9.24 \\
\hline General & 148,50 & 37,36 & 21,12 & 9,70 & 14.07 & 9,33 \\
\hline $\begin{array}{l}\text { Short period } \\
\text { off-take }\end{array}$ & 59.40 & 59.41 & 32.46 & 9.70 & 16.59 & 9.33 \\
\hline Emergency & 66.82 & 59.41 & 32.46 & 9.70 & 16.59 & 9.33 \\
\hline \multicolumn{7}{|l|}{$\begin{array}{l}\text { Reactive ener- } \\
\text { 3y (centimes } \\
\text { per kVA/min) }\end{array}$} \\
\hline $\begin{array}{l}\text { (invoicing } \\
\text { (rebate }\end{array}$ & & \multicolumn{3}{|c|}{$\begin{array}{l}2.65 \\
1.05\end{array}$} & \multicolumn{2}{|c|}{$\begin{array}{l}1.76 \\
0.70\end{array}$} \\
\hline
\end{tabular}

TABLE II 8 : TARIFF FOR SURVEY OF CURRENT IN THE 5-TO 30-KV RANGE, EXCLUDING VAT $(17,6 \%)$ 


\subsubsection{Fixed_operating_cost}

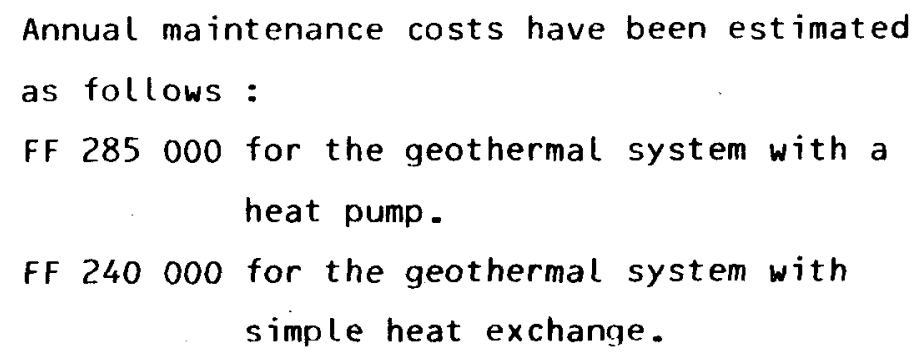

\subsubsection{Energy data}

The efficiency of the fossil fuel boiler has been set at 0.7. The equivalence in tonnes oit equivalent of the electrical power (expressed in $\mathrm{kWh}$ ) is as follows : 1 toe $=4500 \mathrm{kWh}$.

\subsubsection{General data}

No use has been made of the possibility of switching off the heat pumps or the down-hole pumps at EDF peak periods.

on the other hand, it has been assumed that a single EDF contract covers the entire electrical plant, auxiliary drilling pumps and heat pumps.

\subsection{THE CIRCUITS USED}

2.3.1. Use of geothermal energy with simple heat transfer The circuit where geothermal energy is used without a heat pump includes a geothermal heat exchanger, auxiliary boiler and the dwellings to be heated.

2.3.2. Use of geothermal energy with heat pump Several types of circuit have been considered, i.e. those drawn up by the OET (not included in this report) and those of the EDF as illustrated in Figure II.9. 


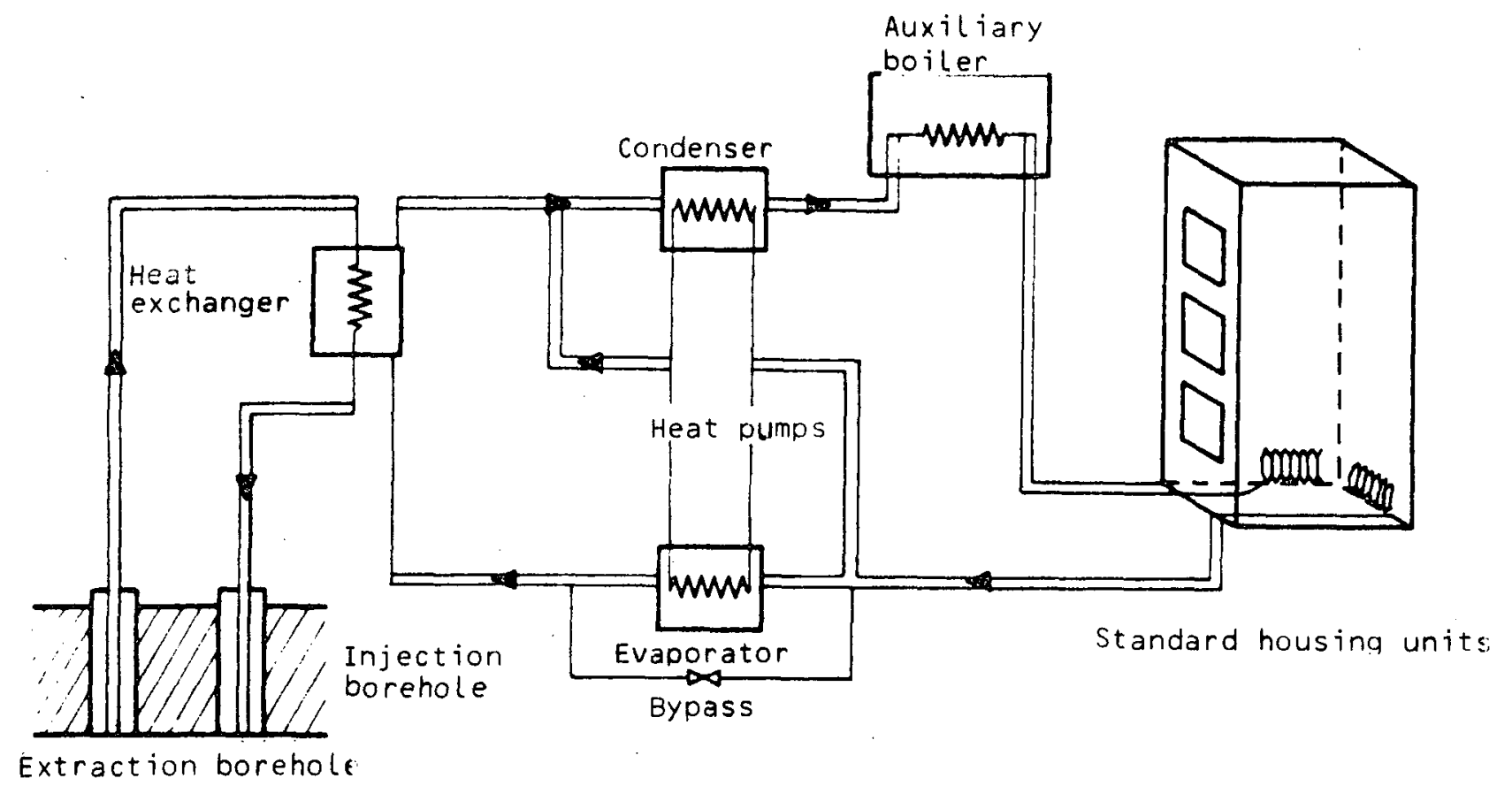

FIGLRE II.9 : C.IRCUIT FOR A GEOTHERMAL HEATING SYSTEM WITH HEAT PUMPS.

The circuit shown in Figure II.9 operates in different forms to meet the outside temperature conditions, i.e. A. Where the outside temperature is sufficiently high for the geothermal energy to provide heat by single transfer, the heat pump is switched off. This eventuality is described in paragraph 2.3.I.

B. The heat pump is switched on, keeping the flow rates in the primary and secondary circuits in the geothermal heat exchanger at the same level. The evaporator cools part of the fluid returning from the heating unit whereas the condenser raises the heat level of the mixture consisting of the water leaving the exchanger and the return water. 
c. A bypass cuts out the evaporator when the temperature difference between the condenser outlet and the evaporator outlet is too low $\left(18^{\circ} \mathrm{C}.\right)$.

D. The fossil fuel auxiliary boiler is put into operation to provide the requisite additional heating during the coldest period.

\subsection{RESULTS OF THE PROGRAM}

As can be seen from the simplified flow chart (see figure II.1.), the initial calculations are designed to identify the annual requirements of the heating plant on the basis of data relating to climate and utilization. In the following graph (figure II.10) we have summarized these results, showing the relationship between the number of standard housing units and the annual consumption expressed in $G$ Joules or $G$ cal $\left(10^{9}\right.$ Joules or $10^{9}$ calories).

If the actual heating requirements of the urban area in question are known, it is possible to calculate the number of standard housing units; this is the main parameter in all the nomograms constructed on the basis of the calculation results.

For a given project, e.g. using the data given in Table II.2., the computer program can provide a number of interesting results on which a decision can be made as to whether or not to use geothermal heating. In particular, it shows the economic balance sheets (see Table II.12.), the energy balances (see Table II.13) and the curves showing the trend in the coefficient of efficiency of the heat pump, the temperature of the re-injected water and the curve of the load on the installation.

In order to compare the various options, we have selected four criteria on the basis of which we can examine the influence of the totality of the variables on the design of the installation : these criteria also served as the basis for plotting the nomograms. 


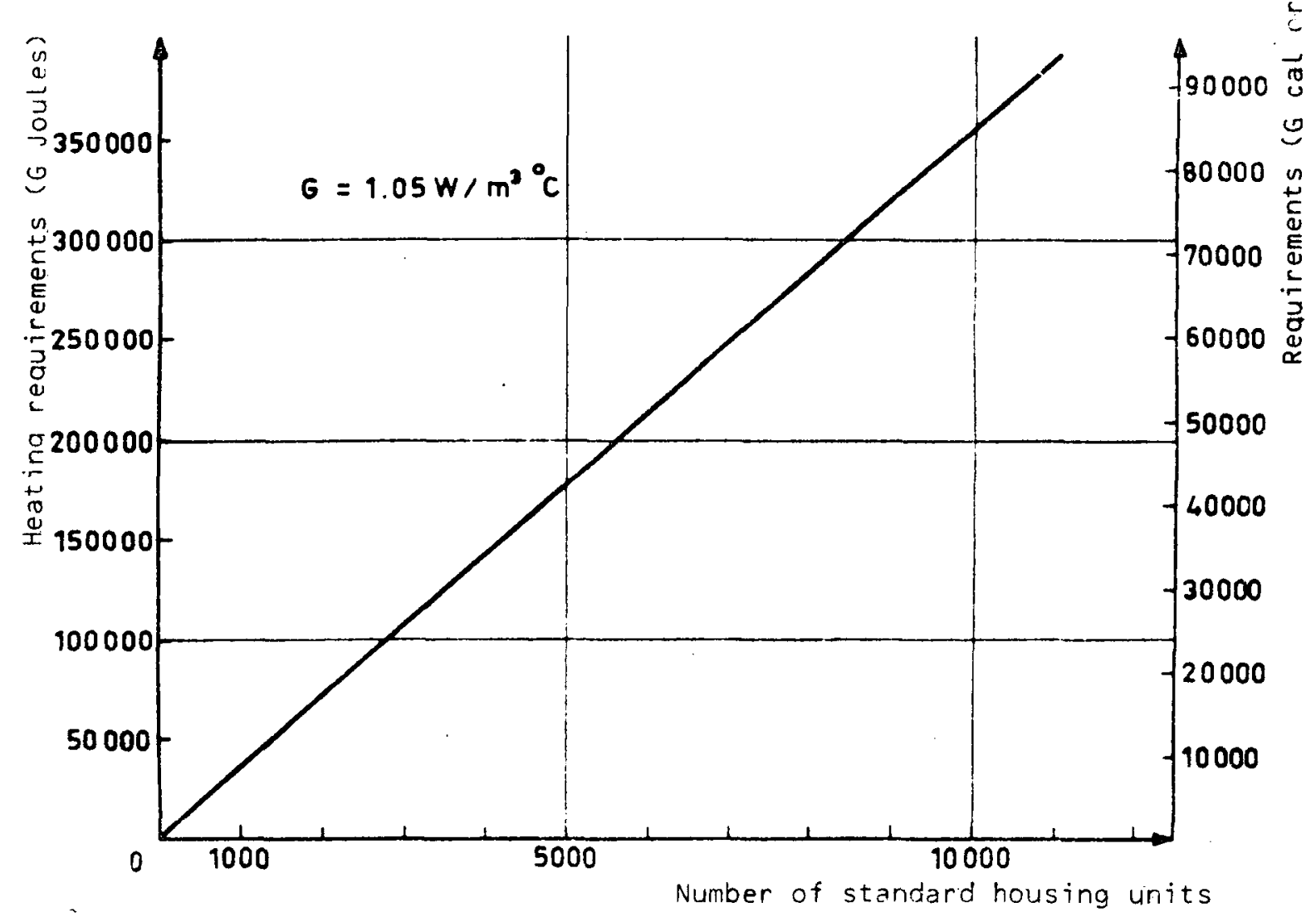

FIGURE I1.10: ANNUAL HEATING REQUIREMENTS AS A FUNCTION OF THE NUMBER OF STANDARD HOUSING UNITS.

Energy criteria

The geothermal efficiency $E$ is the proportion of geothermal energy in the total energy consumption of the housing units, i.e. the total residential heating requirements and the consumption of the auxiliary plant; $E$ is expressed as a percentage.

The criterion complementary to the geothermal efficiency $E$ is the proportion of fossil-fuel energy in the total energy consumption of the housing units, also called "topping-up". For each calculation, a comparison of primary energy consumption is made between geothermal heating and conventional heating. For each plant calculate the savings in tonnes oil equivalent obtained by the construction of a geothermal heating system (toe saved). 


\section{Economic criterion}

The only economic criterion which can be used to compare various heating systems is the discounted cost per useful thermie. This cost is calculated on the basis of the investment required for the project and the operating cost. Since the official discount rate in france is $9 \%$, we have applied this rate over a period of 20 years.

\section{GENERAL DATA}

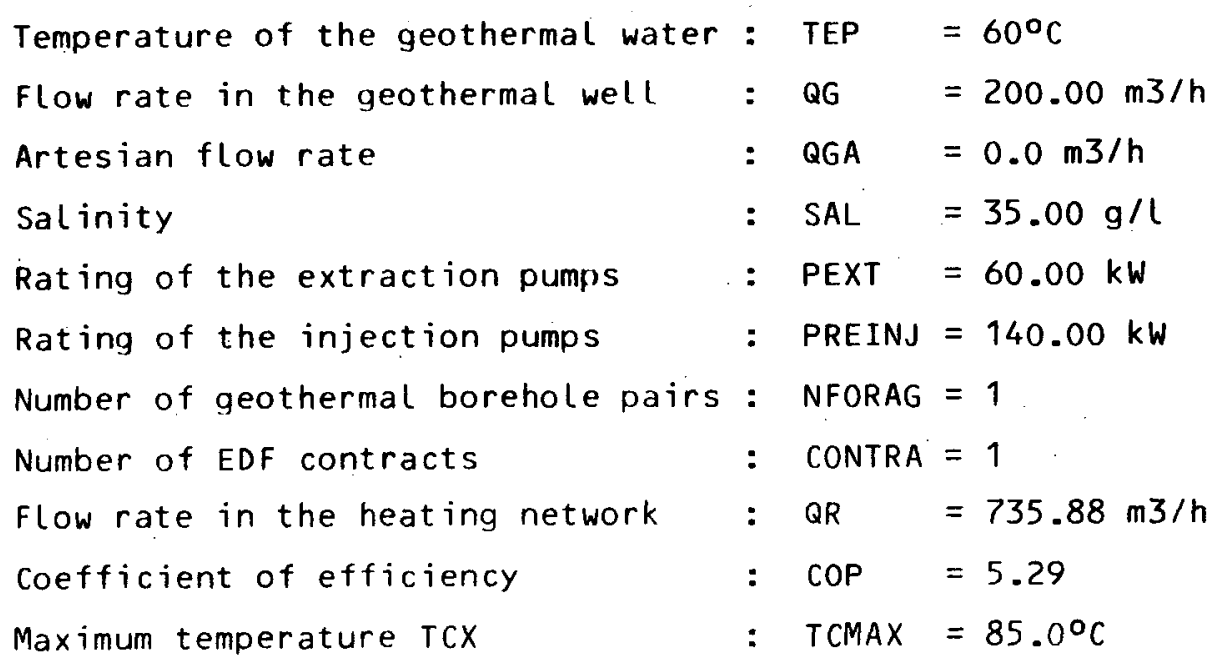

\section{OPERATING DATA}

First "user"

\begin{tabular}{|c|c|c|c|}
\hline Type of heating unit & : & $\begin{array}{l}\text { Under } \\
(70.0\end{array}$ & $\begin{array}{l}\text { Loor heating } \\
50.0^{\circ} \mathrm{C} \text { ) }\end{array}$ \\
\hline Insulation coefficient & $:$ & GLGT & $=1.05 \mathrm{~W} / \mathrm{m} 3 /{ }^{\circ} \mathrm{C}$ \\
\hline volume of a standard housing unit & : & VLGT & $=186.00 \mathrm{~m} 3$ \\
\hline For an external temperature of & : & TEXT & $=-6^{\circ} \mathrm{C}$ \\
\hline Inlet temperature of utilization & : & TEU & $=69.8^{\circ} \mathrm{C}$ \\
\hline Outlet temperature of utilization & : & TSU & $=49.9^{\circ} \mathrm{C}$ \\
\hline Heat flow of utilization & : & PU & $=14658.7 \mathrm{th} / \mathrm{h}$ \\
\hline Flow rate of utilization & $:$ & QU & $=735.9 \mathrm{~m} 3 / \mathrm{h}$ \\
\hline Number of housing units & : & NLGT & $=3500$ \\
\hline
\end{tabular}




\section{GEOTHERMAL HEATING SYSTEM INCORPORATING HEAT PUMPS}

INVESTMENT

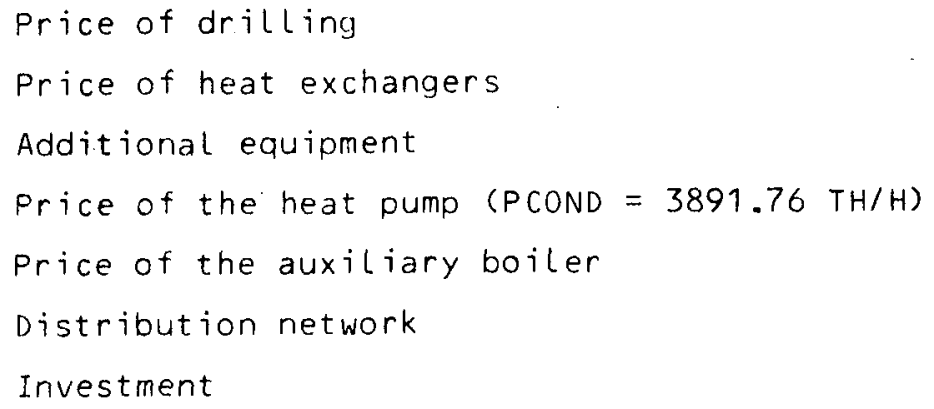

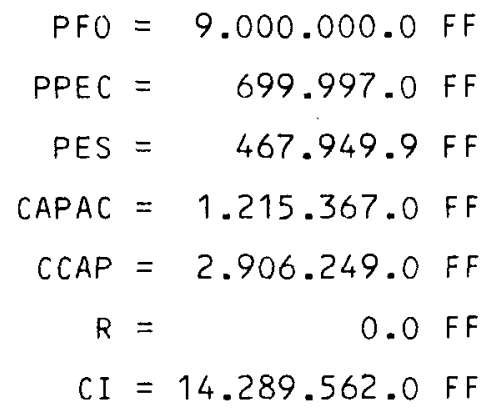

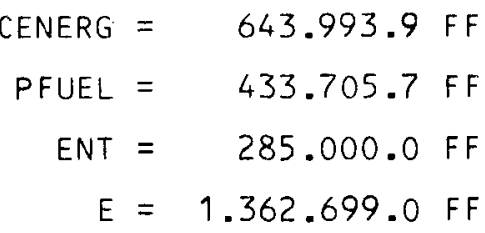

$\begin{array}{rr}B I L=27.276 .080 .0 \mathrm{FF} \\ C I P= \\ E P= & 52.4 \% \\ C T H U= & 0.09632 \quad \mathrm{FF}\end{array}$

\section{GEOTHERMAL HEATING WITHOUT HEAT PUMPS}

Investment

Cost of electricity

Maintenance cost

operating cost

Proportion of the investment as a percentage in the balance-sheet total

$$
\begin{aligned}
\text { CI } & =13.813 .967 .0 \mathrm{FF} \\
\text { CENERG } & =246.501 .6 \mathrm{FF} \\
\text { ENT } & =245.000 .0 \mathrm{FF} \\
E & =1.438 .115 .0 \mathrm{FF} \\
C I P & = \\
& 50.2 \%
\end{aligned}
$$


Proportion of the operating cost as a percentage in the balance-sheet total

Cost per useful thermie

\section{CONVENT IONAL SYSTEM}

Investment

Operating cost

Proportion of the investment as a percentage in the balance-sheet total

Proportion of the operating cost as a

percentage in the balance-sheet total

Cost per useful thermie
$E P=\quad 49.9 \%$

CTHU $=0.09717$ FF

TABLE II. 12 
REQUIREMENTS: 124213.69 GJ (GJ $=10^{9}$ Joules)

EXPRESSED AS

PRIMARY ENERGY

\section{GEOTHERMAL HEATING WITH HEAT PUMPS}

Electricity consumption

$12162.87 \mathrm{GJ}$ or $8.74 \%$
$18128.89 \mathrm{GJ}$ or $14.07 \%$
$99526.62 \mathrm{GJ}$ or $77.22 \%$

Energy required for driling

GEOTHERMAL HEATING WITHOUT HEAT PUMPS

Electricity consumption

Consumption of auxiliary energy

Energy required for arilling

CONVENTIONAL HEATING SYSTEM (FUEL OIL,

GAS OR COAL)

Electricity consumption

Consumption of auxiliary energy

$1062.90 \mathrm{GJ}$ or $0.85 \%$
$124213.69 \mathrm{GJ}$ or $99.15 \%$

4669.14 GJ or

3.628

39568.48 GJ. or

$30.70 \%$

$84683.69 \mathrm{GJ}$ or

$65.71 \%$
1 toe $=4500 \mathrm{kWh}$

25898.42 GJ $(n=0.7)$

695.17 toe

619.58 toe

1 toe $=4500 \mathrm{kWh}$

$56526.39(\eta=0.7)$

288.19 toe

1352.31 toe

1 toe $=4500 \mathrm{kWh}$

$177447.00 \mathrm{GJ}(\eta=0.7)$
65.60 toe

4245.14 toe

AMOUNT OF ENERGY SAVED BY USING A GEOTHERMAL SYSTEM WITH

HEAT PUMPS :

2995.99 toe

AMOUNT OF ENERGY SAVED BY USING A GEOTHERMAL SYSTEM

EMPLOYING SIMPIE HEAT TRANSFER:

2670.25 toe

TABLE II. 13 


\section{PART THREE}

INFLUENCE OF THE MAIN VARIABLES ON A GEOTHERMAL PROJECT 
III. INFLUENCE OF THE MAIN VARIABLES ON A GEOTHERMAL PROJECT

In some cases, the specific nature of a geothermal operation may have an impact in the energy field, and hence on the economy; in others it may have a solely economic impact.

As regards the boreholes and the network, first of all, the flow rate, water temperature and pumping capacity will directly affect the energy balance of a geothermal heating project, whereas the chemical properties of the water and the addition of a distribution network will have an essentially economic impact.

As regards the centrally-situated heating plant, the choice of system and the capacity of the heat pumps will affect the energy balance, whereas the quality of the fossil energy will affect only the economics of the operation.

The size of an installation is determined chiefly by its users, although factors like climate, the number of standard housing units and the temperatures on entry to and return from the heating system will affect energy and economic results.

In addition, the costs of materials and discounting rates and periods will directly affect the economic viability of a project.

3.1. THE BOREHOLES AND . THE NETWORK

3.1.1. Effect of flow rate and temperature of the geothermal water

These features of the geothermal resource are obviously of fundamental importance in any geothermal project. 
However, it is possible for the positive nature of one of these factors to make up for a weakness of the other. In other words, geothermal efficiency with simple heat transfer is largely the same if a geothermal resource provides :

(i) $100 \mathrm{~m}^{3} / \mathrm{h}$ of water at $80^{\circ} \mathrm{C}$ or $150 \mathrm{~m}^{3} / \mathrm{h}$ of water at $60^{\circ} \mathrm{C}$ for 3000 housing units with $55 / 40^{\circ} \mathrm{C}$ underfloor heating (see Figure III.1);

(ii) $120 \mathrm{~m}^{3} / \mathrm{h}$ of water at $80^{\circ} \mathrm{C}$ or $250 \mathrm{~m}^{3} / \mathrm{h}$ of water at $60^{\circ} \mathrm{C}$ for 3000 housing units installed with internal systems which have inlet temperatures of $70^{\circ} \mathrm{C}$ and outlet temperatures of $50^{\circ} \mathrm{C}$ (see Figure III.2); or

(iii) $160 \mathrm{~m}^{3} / \mathrm{h}$ of water at $80^{\circ} \mathrm{C}$, if these 3000 housing units are heated by $90 / 70^{\circ} \mathrm{C}$ radiators (see Figure III.3).

For the geothermal heating of 3000 housing units with underfloor heating with simple heat transfer, geothermal efficiency is $50 \%$ with :

(i) $300 \mathrm{~m}^{3} / \mathrm{h}$ of water at $40^{\circ} \mathrm{C}$;

(ii) less than $100 \mathrm{~m}^{3} / \mathrm{h}$ of water at $60^{\circ} \mathrm{C}$;

(iii) $60 \mathrm{~m}^{3} / \mathrm{h}$ of water at $80^{\circ} \mathrm{C}$.

With other methods of heating $190 / 70^{\circ} \mathrm{C}$ or $70 / 50^{\circ} \mathrm{C}$ radiators), efficiency will not exceed $40 \%$ with water at $40^{\circ} \mathrm{C}$ whatever the geothermal flow.

Comparing the curves with or without heat pumps shows the energy benefits of such pumps, particulary at low geothermal temperatures. On curve III. 2 for example, the heat pump doubles geothermal efficiency at $40^{\circ} \mathrm{C}$ and increases it by some 108 at $60^{\circ} \mathrm{C}$ and by a few per cent at $80^{\circ} \mathrm{C}$, when flow rates are more than $200 \mathrm{~m}^{3} / \mathrm{h}$.

Furthermore, although with simple heat transfer, increasing the geothermal flow always increases geothermal efficiency, with a 


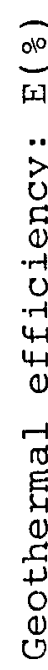

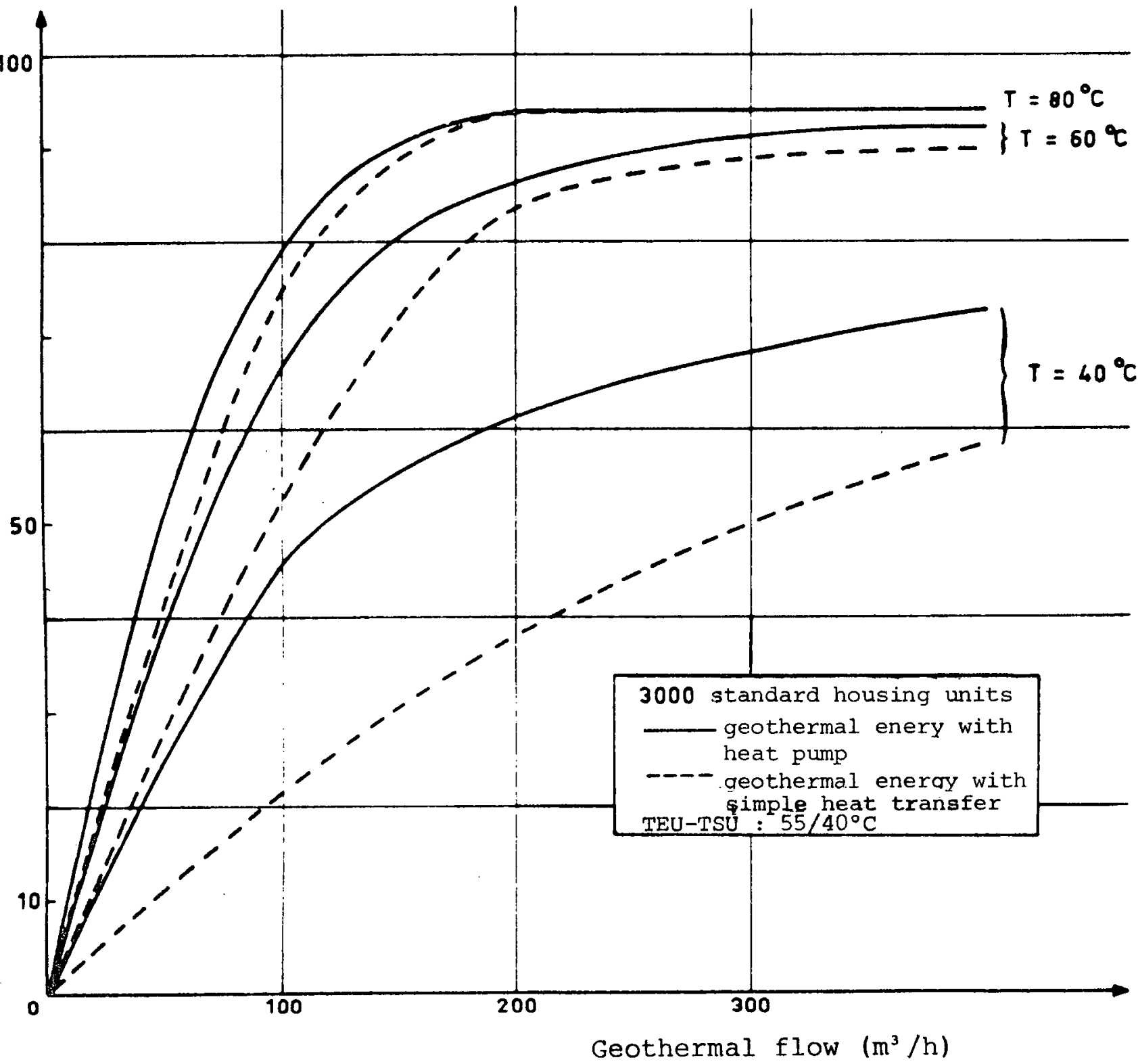

FIGURE III.1 : INFLUENCE OF GEOTHERMAL CONDITIONS (TEMPERATURE AND FLOW) ON GEOTHERMAL EFFICIENCY $\left(55 / 40^{\circ} \mathrm{C}\right.$ UNDER-FLOOR HEATING). 


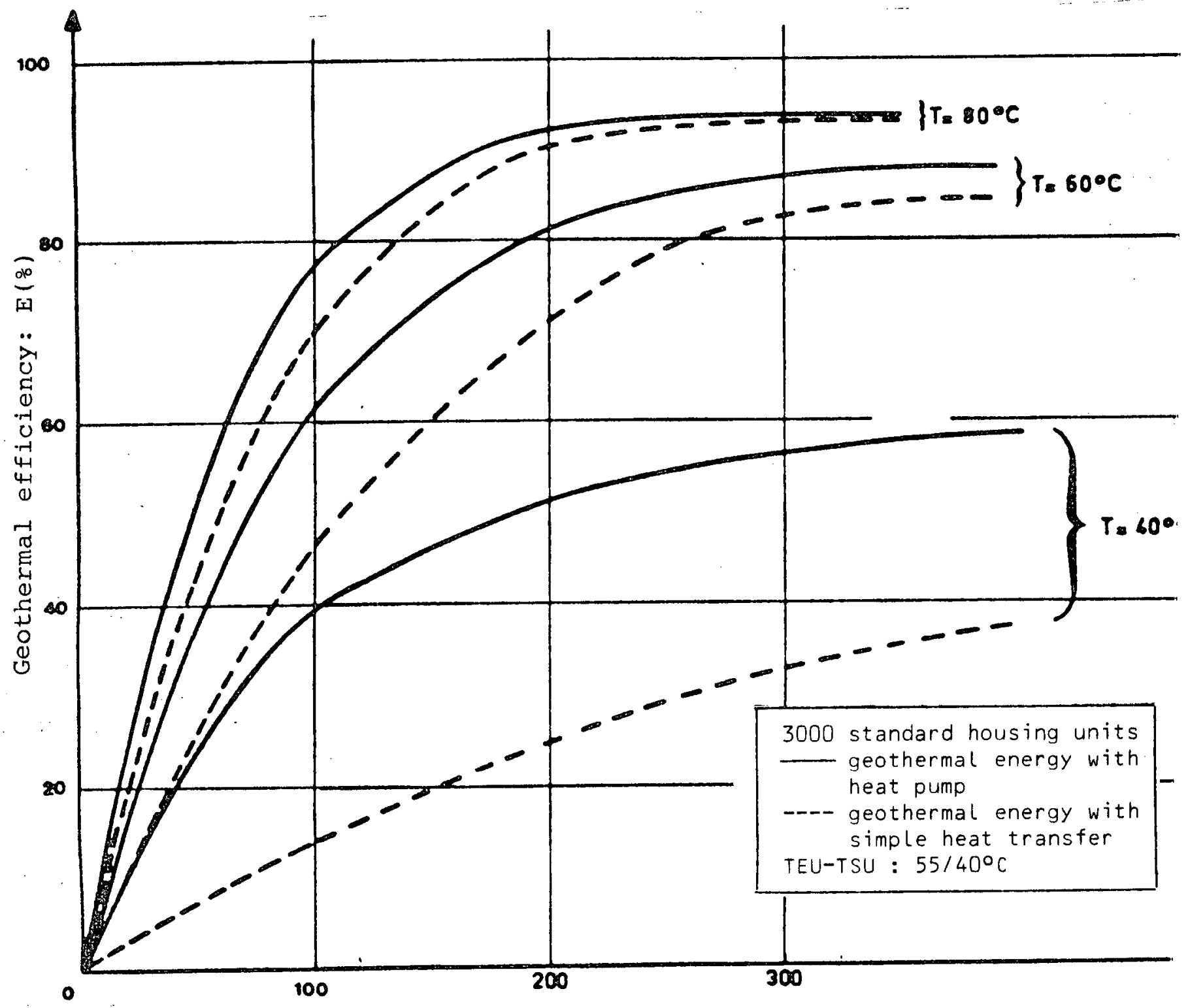

Geothermal flow $\left(\mathrm{m}^{3} / \mathrm{h}\right)$

FIGURE III. 2 : INFLUENCE OF GEOTHERMAL CONDITIONS (TEMPERATURE AND FLOW) ON GEOTHERMAL EFFICIENCY $\left(70 / 50^{\circ} \mathrm{C}\right.$ RADIATORS ) 


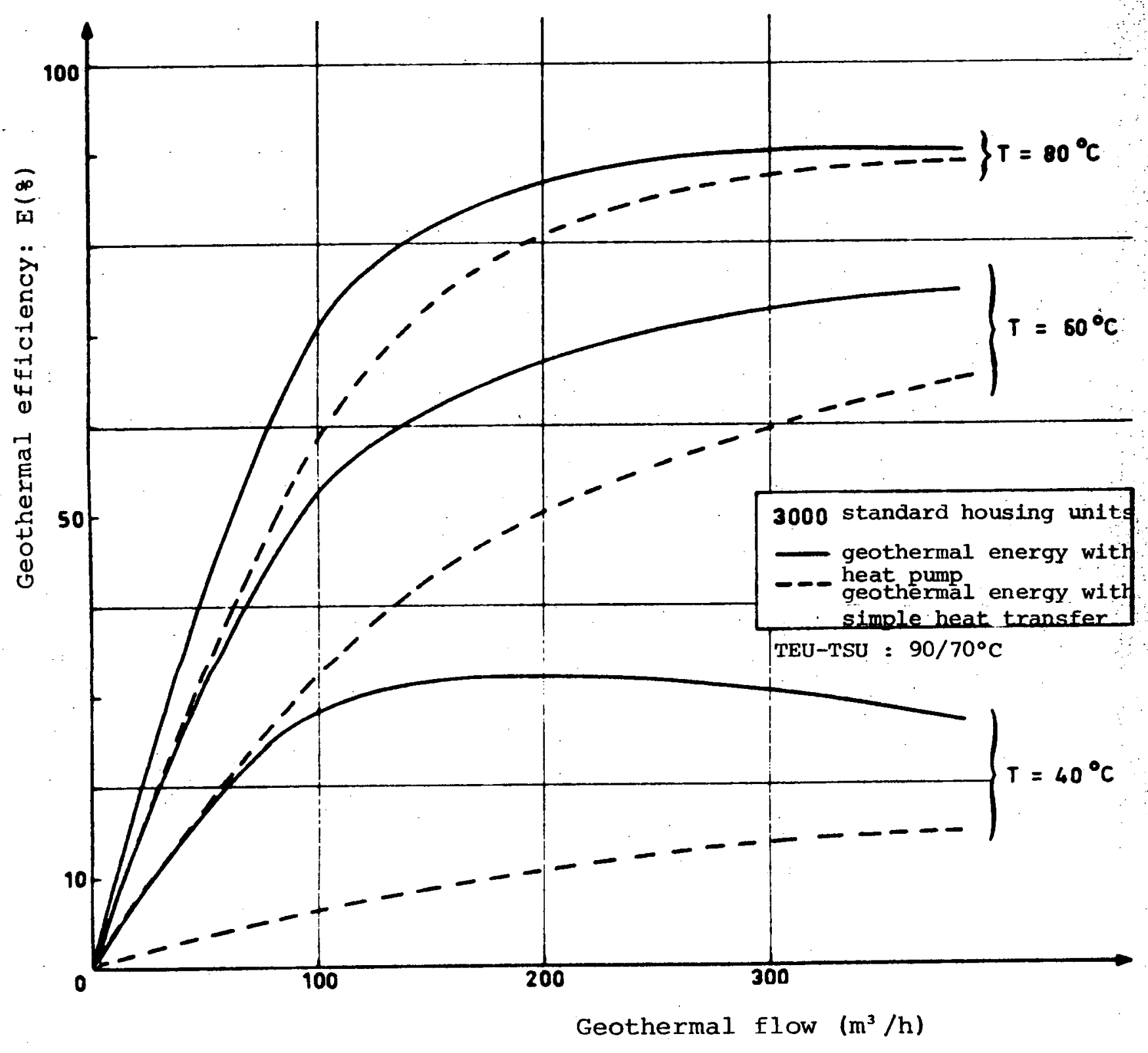

FIGURE III. 3 : INFLUENCE OF GEOTHERMAL CONDITIONS (TEMPERATURE AND FLOW) ON GEOTHERMAL EFFICIENCY $\left(90 / 70^{\circ} \mathrm{C}\right.$ RADIATORS) 
heat pump it has only a limited, or even negative, effect on geothermal efficiency when then geothermal temperature is low $\left(40^{\circ} \mathrm{C}\right)$ and there is a high-temperature heating system $190 / 70^{\circ} \mathrm{C}$, $\left.70 / 50^{\circ} \mathrm{C}\right)$.

From the energy point of view however, it should be stressed that, for geothermal water at low temperatures boosting the geothermal flow by pumping, if the porosity of the aquifer allows, is generally less beneficial than adding heat pumps.

In Figure III.1., for example, the extra energy contributed by the heat pump in the case of a borehole with a flow rate of $100 \mathrm{~m}^{3} / \mathrm{h}$ at $40^{\circ} \mathrm{C}$ corresponds to an increase in flow of $150 \mathrm{~m}^{3} / \mathrm{h}$, whereas with a flow rate of $100 \mathrm{~m}^{3} / \mathrm{h}$ of water at $60^{\circ} \mathrm{C}$, the increase in geothermal efficiency due to the heat pump is only equivalent to an extra flow of some $40 \mathrm{~m}^{3} / \mathrm{h}$ of water.

The advantage of increasing the flow of geothermal water increases wit the temperature of the water, as can be seen from Figure III.4. However, it also depends on the energy needs of the housing units, in other words the number of units and the temperature of their heating systems.

For example, if 3500 housing units are heated by $70 / 50^{\circ} \mathrm{C}$ radiators, increasing the flow from 200 to $300 \mathrm{~m}^{3} / \mathrm{h}$ improves geothermal efficiency only very slightly, even if the geothermal water is at a temperature of $60^{\circ} \mathrm{C}$. 


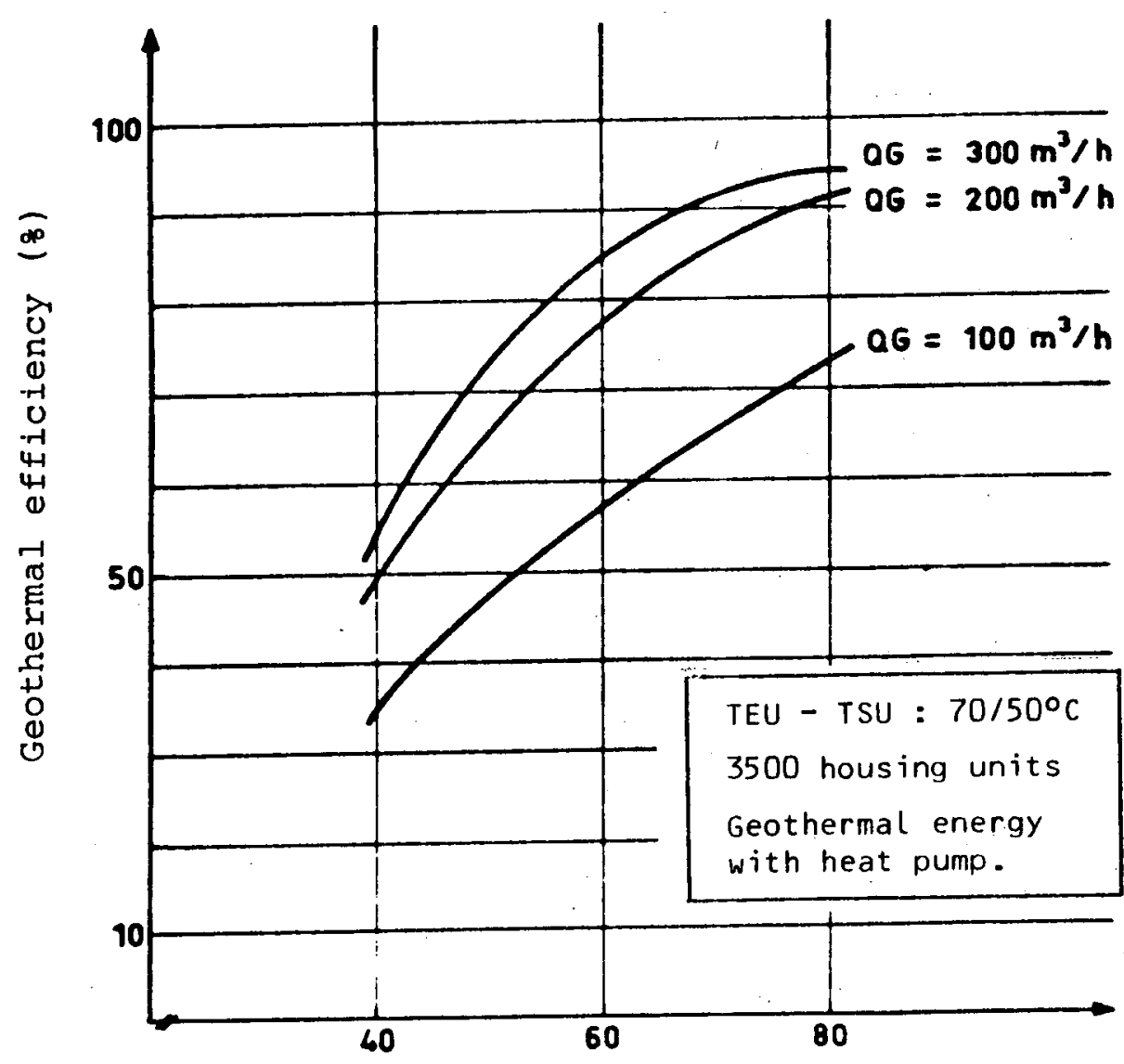

Geothermal temperatures $\left({ }^{\circ} \mathrm{C}\right)$

FIGURE III.4 : INFLUENCE OF GOETHERMAL TEMPERATURE ON GEOTHERMAL EFFICIENCY FOR DIFFERENT GEOTHERMAL FLOW RATES.

Under these circumstances, the cost of a useful thermie of heat is the same for $100 \mathrm{~m}^{3} / \mathrm{h}$ at $80^{\circ} \mathrm{C}$ as it is for $200 \mathrm{~m}^{3} / \mathrm{h}$ at $49^{\circ} \mathrm{C}$ or $300 \mathrm{~m}^{3} / \mathrm{h}$ at $46^{\circ} \mathrm{C}$ (see Figure III.5). Whatever the geothermal flow, between 100 and $300 \mathrm{~m}^{3} / \mathrm{h}$ the cost of geothermal heat per thermie will exceed the cost of conventional heating per thermie, if the temperature is lower than $40^{\circ} \mathrm{C}$. 


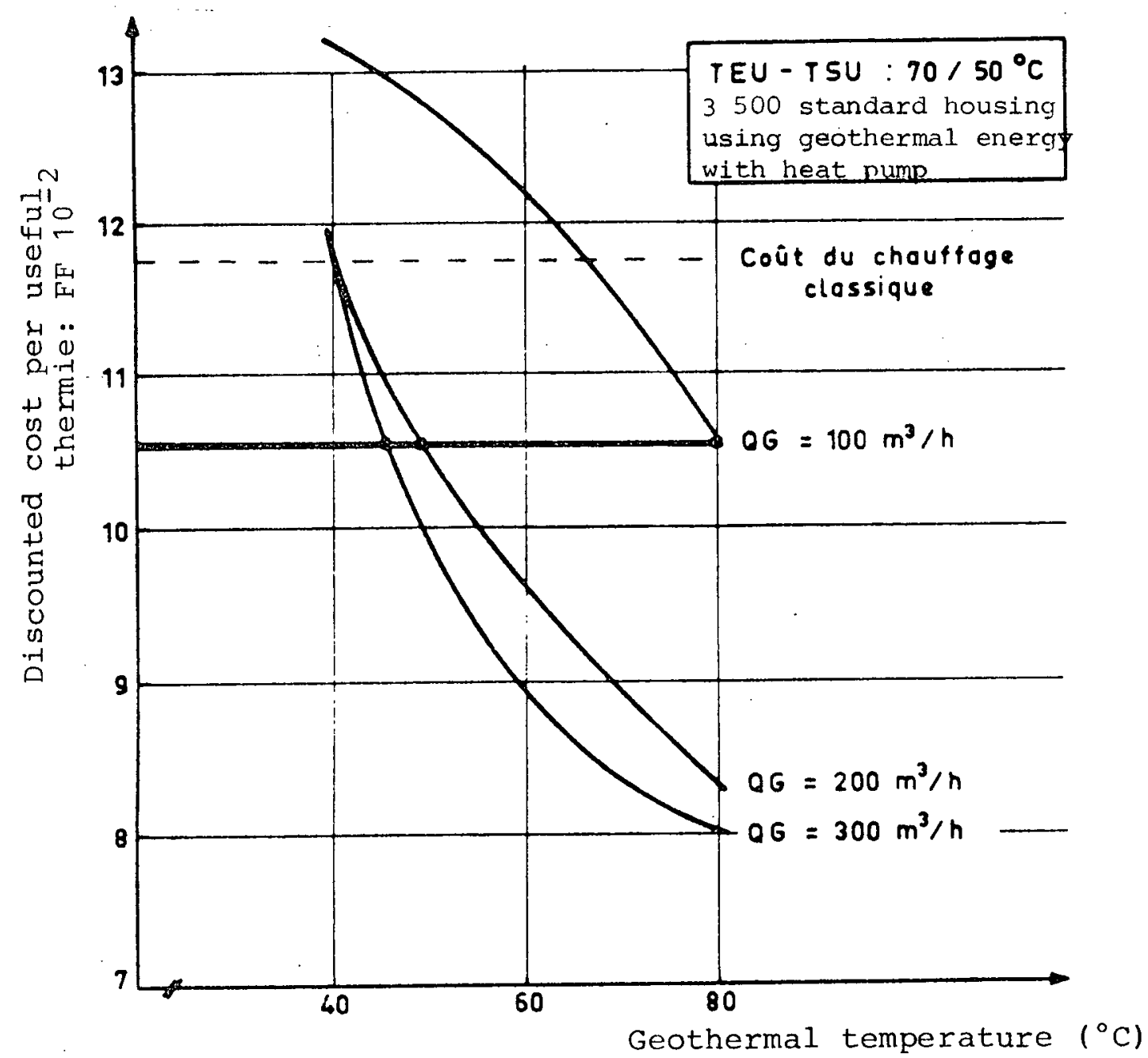

FIGURE III.5 : INFLUENCE OF GEOTHERMAL TEMPERATURE ON THE DISCOUNTED COST PER USEFUL THERMIE FOR DIFFERENT GEOTHERMAL FLOW RATES

For information, Figure III. 6 shows how geothermal temperatures and flow affect the quantity of tonnes oil equivalent (toe) saved. If 3500 housing units with an annual consumption of the order of $30000 \mathrm{kilothermies}$ are fitted with $70 / 50^{\circ} \mathrm{C}$ radiators, it is possible to save 3000 toe with $200 \mathrm{~m}^{3} / \mathrm{h}$ of water at $60^{\circ} \mathrm{C}$ or with $300 \mathrm{~m}^{3} / \mathrm{h}$ of water at some $53^{\circ} \mathrm{C}$. 


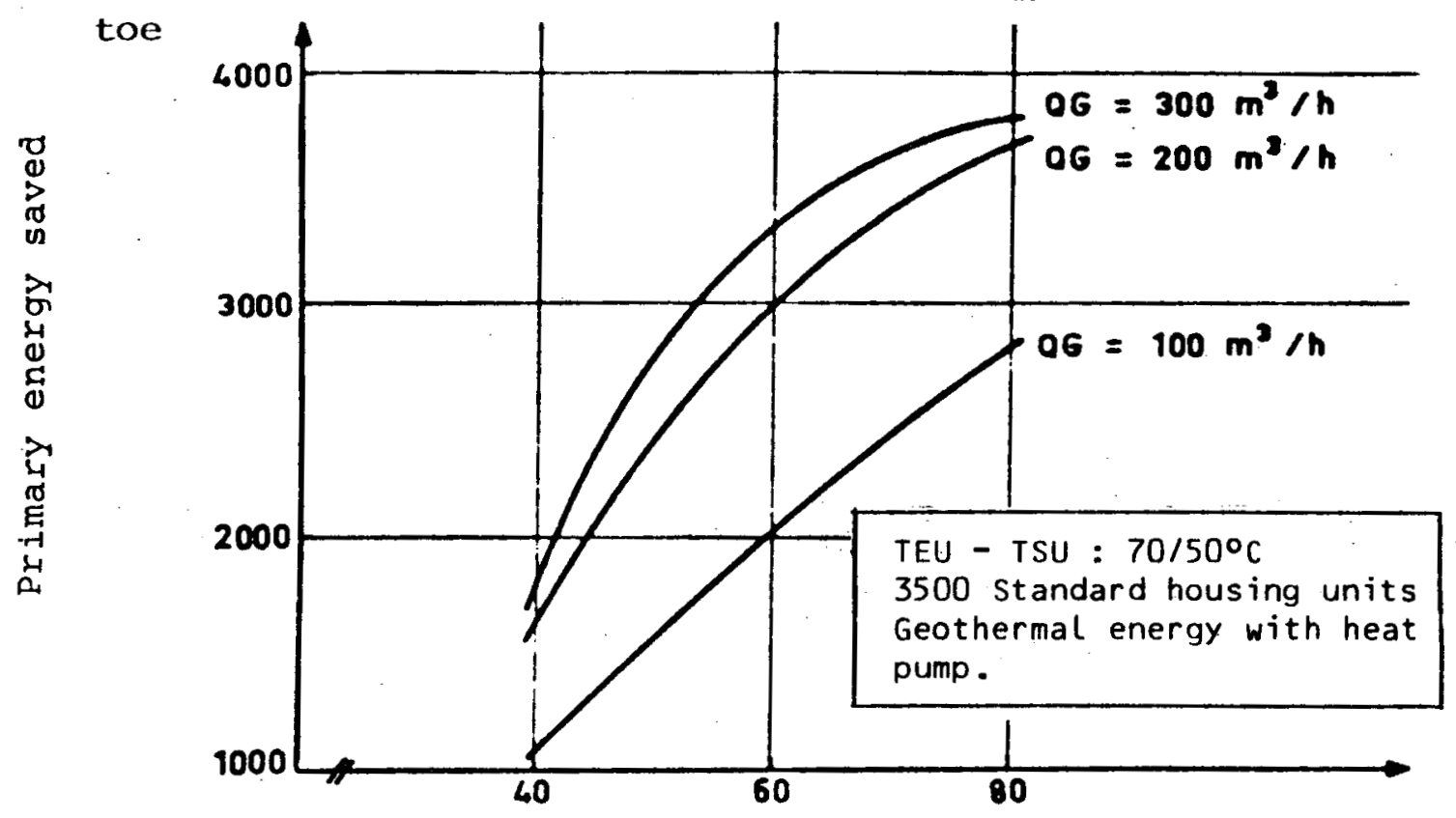

Geothermal temperature $\left({ }^{\circ} \mathrm{C}\right)$

FIGURE III.6 : INFLUENCE OF GEOTHERMAL TEMPERATURE ON SAVINGS OF ENERGY (in toe) FOR DIFFERENT GEOTHERMAL FLOWS .

If the 3500 housing units are heated by $90 / 70^{\circ} \mathrm{C}$ radiators and heat pumps are used, the benefit of increasing the geothermal flow depends more than ever on the temperature of the geothermal water.

If the goethermal water is at $40^{\circ} \mathrm{C}$, efficiency is lower with a flow rate of $300 \mathrm{~m}^{2} / \mathrm{h}$ than with $200 \mathrm{~m}^{3} / \mathrm{h}$, since the extra geothermal calories do not offset the extra energy consumed by the drilling pumps (see Figure III.7).

Similarly, increasing the geothermal flow within the 200 to $300 \mathrm{~m}^{3} / \mathrm{h}$ bracket only reduces the costs of a thermie if the temperature of the geothermal water is more than $47^{\circ} \mathrm{C}$ (see Figure III.8). 


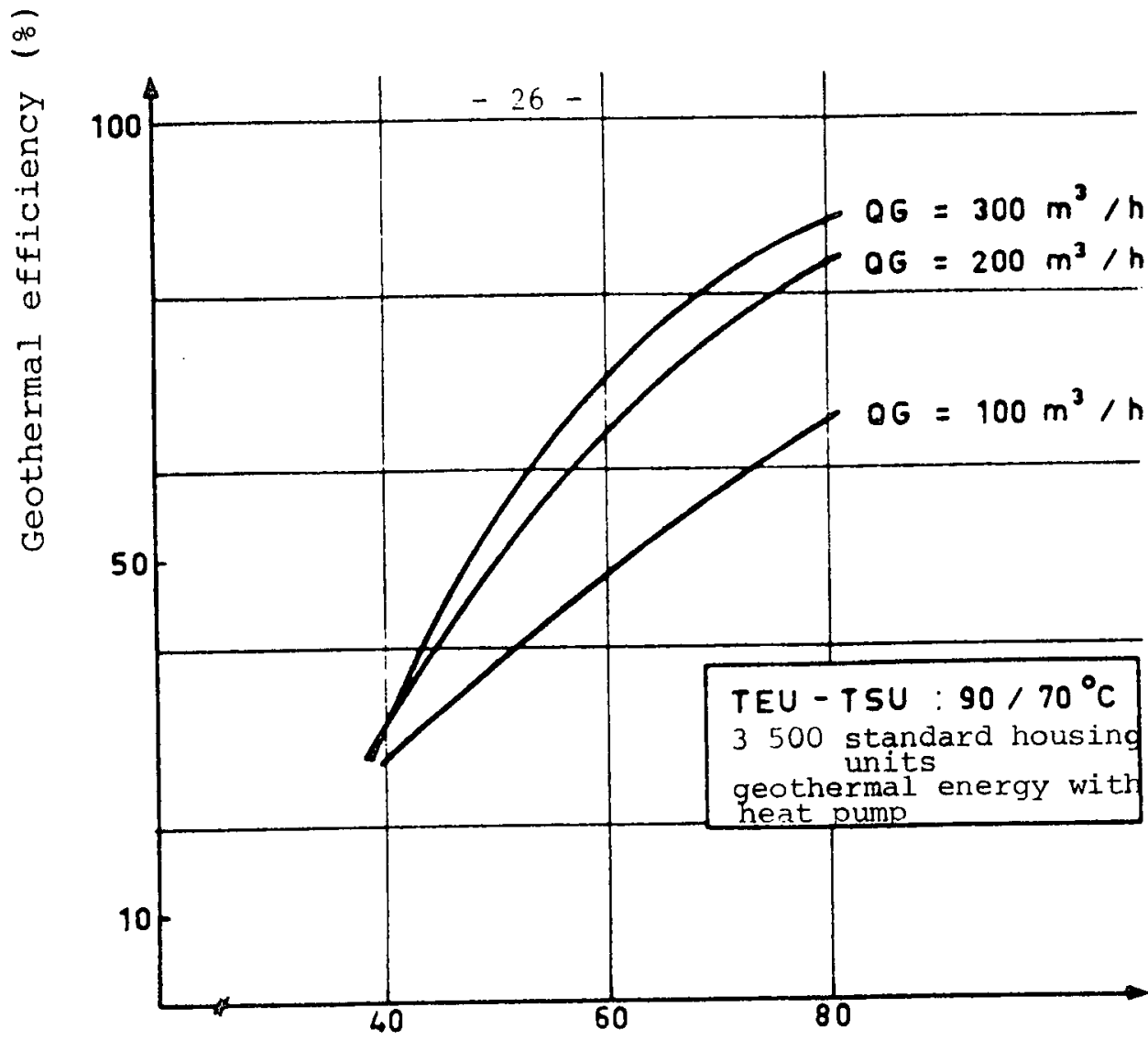

FIGURE III.7 : INFLUENCE OF GEOTHERMAL TEMPERATURE ON GEOTHERMAL EFFICIENCY FOR DIFFERENT GEOTHERMAL FLOWS . 


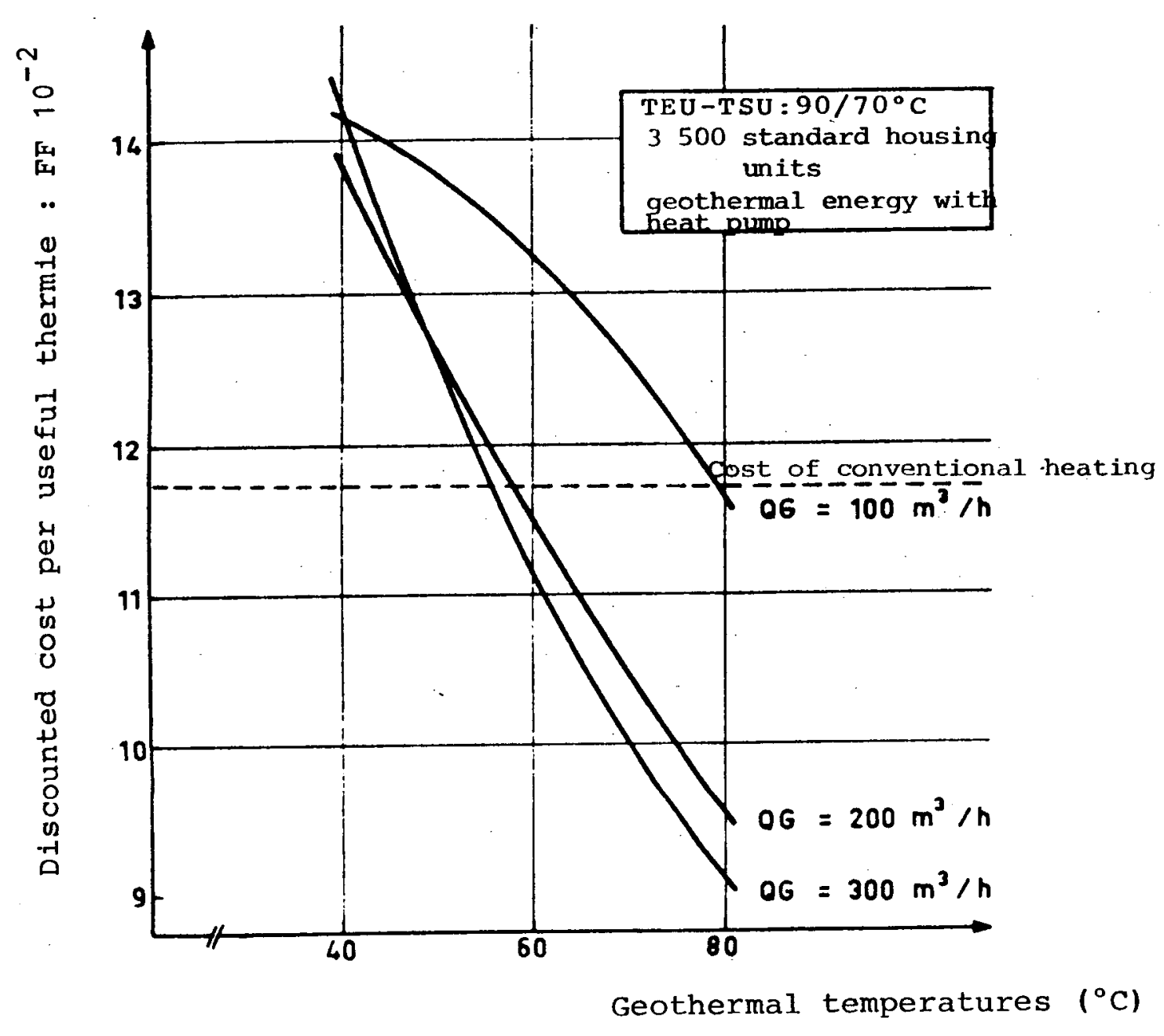

FIGURE III.8 : INFLUENCE OF GEOTHERMAL TEMPERATURE ON DISCOUNTED COST PER USEFUL THERMIE FOR DIFFERENT GEOTHERMAL FLOWS . 


\subsubsection{Importanance_ofof_pumping}

Pumping can be extremely important if there is no artesian flow. In this study, we have had to make various assumptions about pumping capacity (see paragraph II.2) .

In a project to heat 3500 housing units $\left(70 / 50^{\circ} \mathrm{C}\right)$ by means of geothermal water at a temperature of $60^{\circ} \mathrm{C}$ with simple heat transfer, pumping costs represent some 328 of operating costs if the flow rate is $300 \mathrm{~m}^{3} / \mathrm{h}, 178$ if it $1 \mathrm{~s} 200 \mathrm{~m}^{3} / \mathrm{h}$ and 98 if it is $100 \mathrm{~m}^{3} / \mathrm{h}$.

In energy terms, over a year of geothermal heating with simple heat transfer, pumping and auxiliary installations consume in the order of :

(i) $6920 \mathrm{GJ}$, or 427 toe, if flow rate $Q G=300 \mathrm{~m}^{3} / \mathrm{h}$;

(ii) $4670 \mathrm{GJ}$, or 288 toe, if flow rate $Q G=200 \mathrm{~m}^{3} / \mathrm{h}$;

(iii) $3770 \mathrm{GJ}$, or 233 toe, if flow rate $Q G=100 \mathrm{~m}^{3} / \mathrm{h}$;

for 3500 housing units $\left(70 / 50^{\circ} \mathrm{C}\right)$.

The higher the geothermal temperature (see Figure III.9) and the lower the number of housing units, the greater the incidence of pumping costs in the overall operating costs. If there are 2000 housing units and the geothermal water is at $80^{\circ} \mathrm{C}$ and the $Q G$ of $200 \mathrm{~m}^{3} / \mathrm{h}$, pumping costs reach $47 \%$ of running costs, since additional fuel costs account for a much smaller percentage.

\subsubsection{Chemical_cong}

The chemical properties of water, particularly its salinity, have a slight influence on heat exchange between geothermal water and the water in the heating network. However, considering the probable salinity values of geothermal water (between 0 and 150 grams per litre), this factor has only a very slight effect 


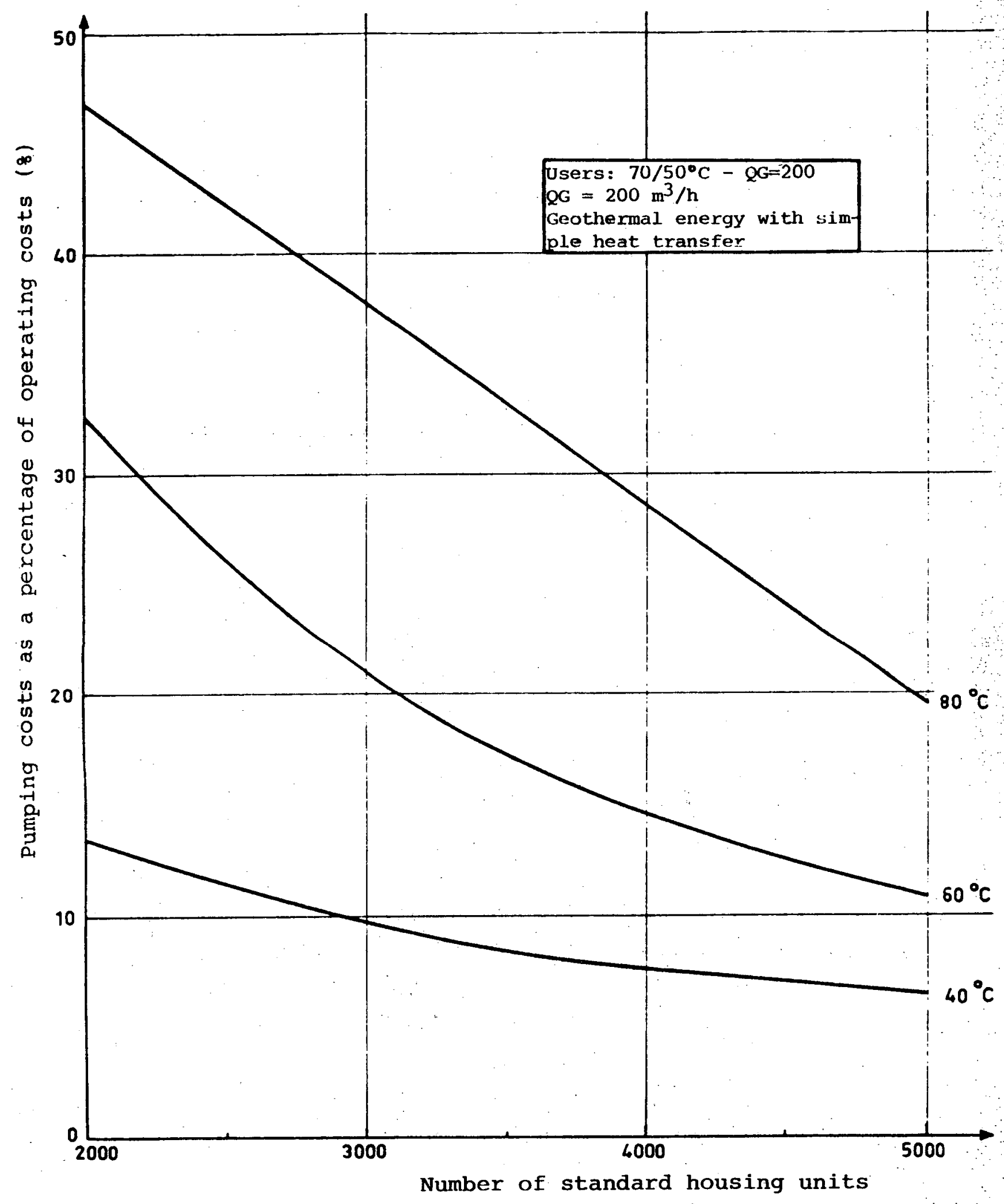

FIGURE III.9 : PUMPING COSTS AS PROPORTION OF OPERATING COSTS AT VARIOUS GEOTHERMAL TEMPERATURES. 
on energy balances. Apart from salinity however, it is often the aggressivity of the water which adds to the cost.

It is possible in fact to have mild, non-aggressive water like that used at Mont-de-Marsan in the South of France, or aggressive geothermal water like that of Creil or Melun in the Paris Basin. If the water is of the first type, the exchanger can be made of stainless steel instead of titanium and the geothermal water can be discharged into streams if it is properly cooled; this yields a substantial investment saving, since a large proportion of the cost of the reinjection borehole is included in the economic balance (see paragraph 3.4).

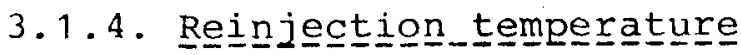

Reinjection temperature very much depends on geothermal heating conditions. If it drops, this a sign that the heat in the geothermal water is being used more fully as a result of improvements to the installation.

The main factors which affect the reinjection temperature are the temperature at which the water returns from the heating systeem and the geothermal temperature, as shown in Figure III.10 and III. 11 .

These curves show how reinjection temperatures change during the heating season, for various geothermal temperatures in the case of 3500 housing units fitted with $70 / 50^{\circ} \mathrm{C}$ radiators. The geothermal flow is $100 \mathrm{~m}^{3} / \mathrm{h}$.

If a heat pump is used in the conventional system for extracting geothermal heat using an exchanger, this substantially reduces the reinjection temperature, as can be seen by comparing Figures III. 10 and III. 11 .

Figure III.10 shows the results obtained from geothermal heating with heat pumps while Figure III.11 shows the reinjection temperatures if simple heat transfer is used. 


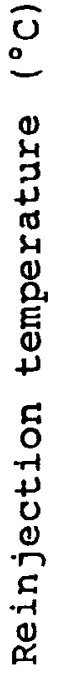

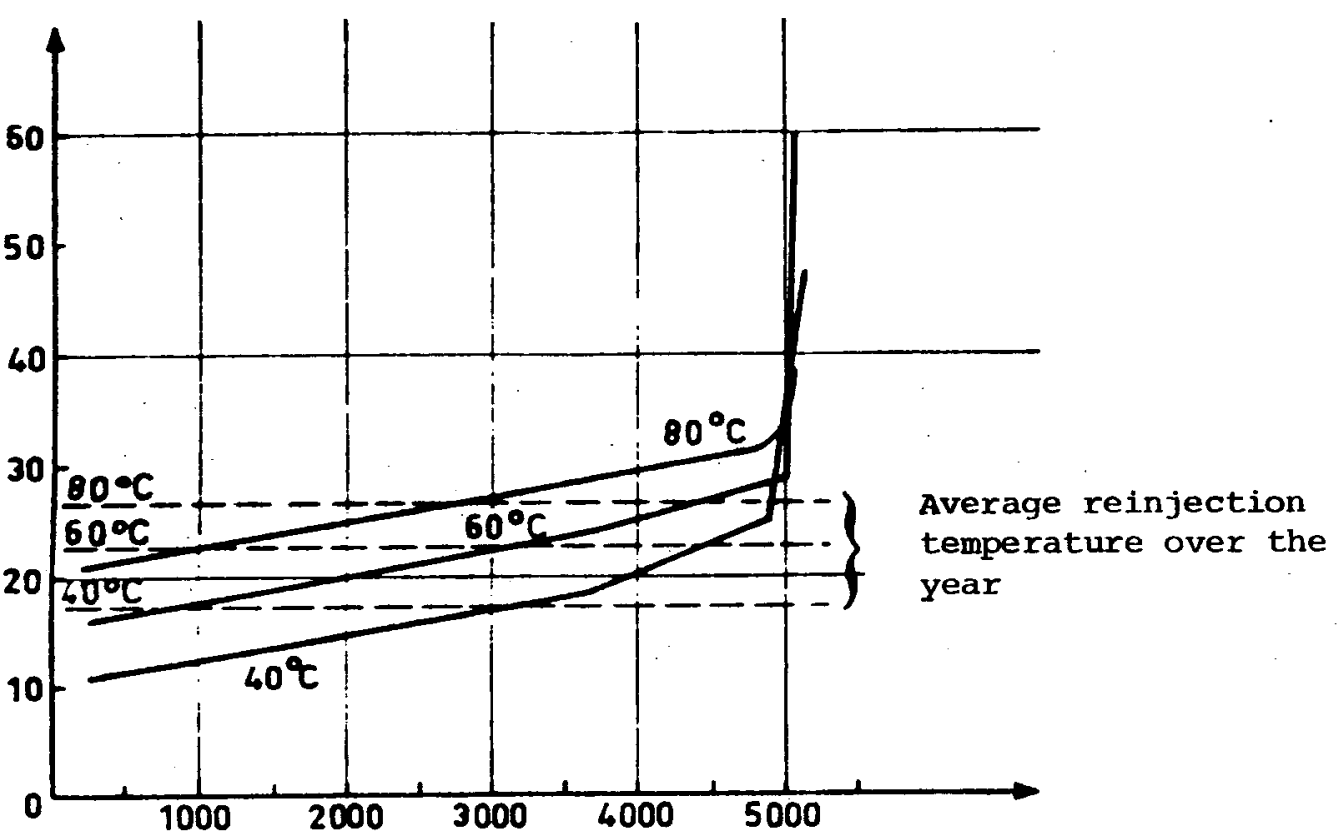

FIGURE III.10: CHANGES IN THE REINJECTION TEMPERATURE DURING ONE HEATING SEASON AND AS A FUNCTION OF SEVERAL, DIFFERENT GEOTHERMAL WATER TEMPERATURES $\left(80^{\circ} \mathrm{C}, 60^{\circ} \mathrm{C}\right.$ and $\left.40^{\circ} \mathrm{C}\right)$. GEOTHERMAL ENERGY WITH HEAT PUMPS.

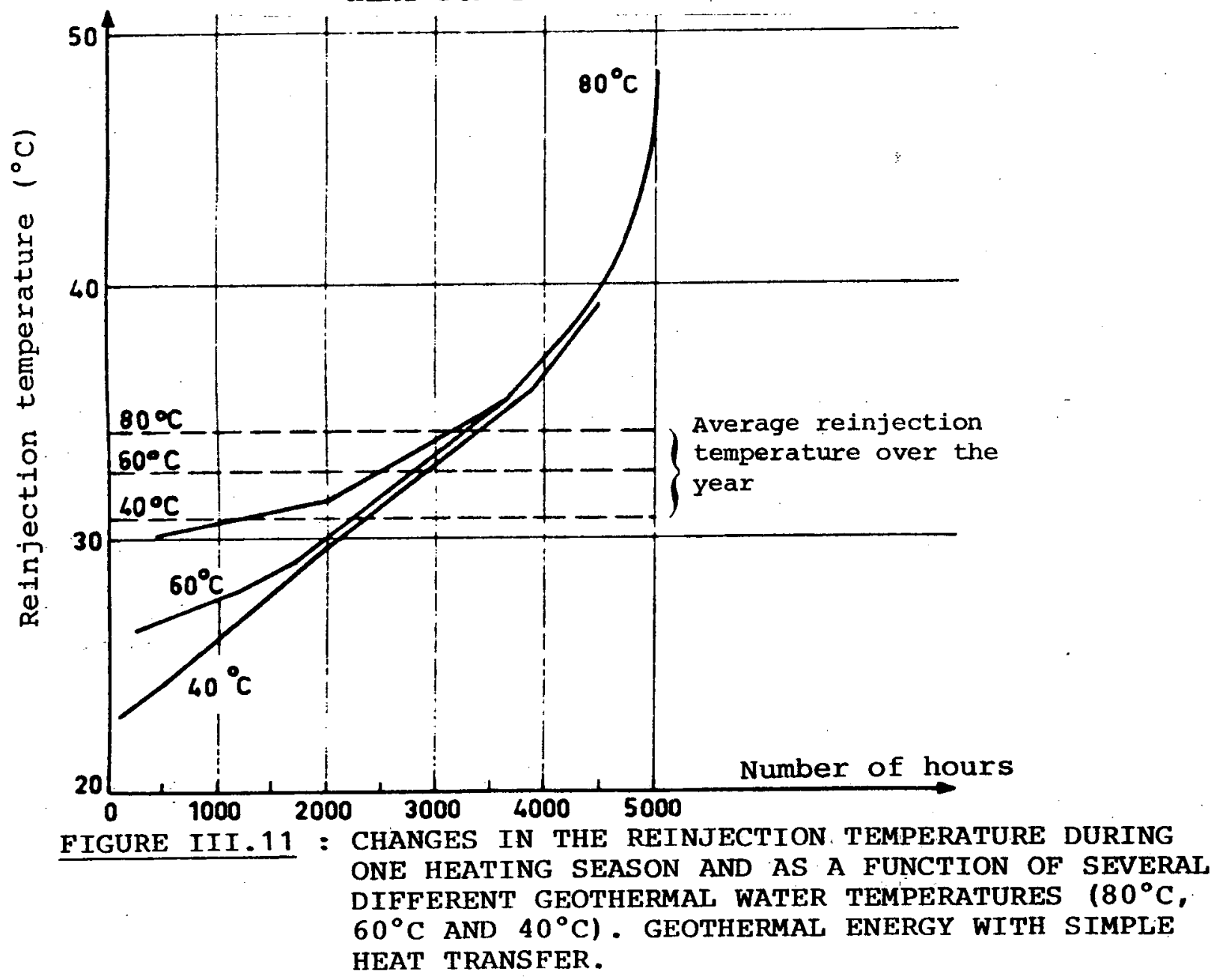




\subsubsection{Networokㅗ}

There can be two kinds of network in a geothermal heating installation :

(i) the geothermal water network, which is called the transfer network and which carries the water from the boreholes to the centrally-situated heating plant and back to the reinjection borehole;

(ii) the network of distributing water for heating to housing units.

The transfer network may be very short if the boreholes are sunk near the housing area, as is the case with the VilleneuveLa-Garenne project in France, or it may extend several kilometres if a number of boreholes are required and cannot be sunk near the centrally-situated heating plant, as is the case at Creil (where the network is 7,300 kilometres).

In the case of Creil, where temperature losses are very slight, we could assume that the temperature of the geothermal water leaving the borehole was the same as the temperature of the water entering the geothermal exchanger.

This transfer network was taken into account to add on a lump-sum cost to the cost of sinking the boreholes (see paragraph 2.5.2).

The study of the distribution network is very important and particularly complicated if detailed plans for the network are not available. In this report, we have made the calculation for the geothermal heating installation independently of the heating network; we have therefore been considering an installation diverced from the network. A special study has been made of distribution networks and a computer calculation programme worked out. The results are given in the form of graphs in Annex 1. 


\section{2. THE CENTRALLY-SITUATED HEATING PLANT}

\subsubsection{Influence of the configuration}

Generally, the centrally-situated heating plant includes the geothermal heat exchangers, the heat pumps and the auxiliary boilers required. The design of these various heating installations has to be specially worked out for each individual case. However, for the purposes of this contract we have elected to study two configurations, one which has been taken over by the OET and is not included in this report and the other which is shown in Figure II.10; it has enabled us to study the influence of different variables and to plot the nomograms which we have included.

Generally, it is only possible to arrive at the optimum configuration if there is full information about the temperature and flow of the geothermal resource and the conditions of use (number of housing units, type of installations, climate, hours of sunshine, etc.).

\subsubsection{Size of the equipment - influence of the exchanger}

An exchanger can be described according to its number of transfer units (NTU) defined as :

$$
\mathrm{NTU}=\frac{\mathrm{KS}}{\mathrm{Min}}
$$

Min is the minimum value of the expression ( $\mathrm{mf} x \mathrm{mh}$ ) calculated for the primary and secondary circuits of the geothermal heat exchanger, where $\mathrm{mf}$ is the mass flow and $\mathrm{mh}$ the mass heat, $\mathrm{K}$ the overall heat transfer coefficient and $s$ the area of the total exchange surface.

This value can also be expressed as the ratio between the temperature difference divided by the hot fluid and the average 
logarithmic difference. It is directly connected with efficiency, defined as the ratio between the quantity of heat actually exchanged and the quantity of heat which can be exchanged.

The greater the NTU, the better the recovery of heat energy, although the cost of the exchanger increases with NTU.

The optimum economic solution should be the objective when selecting the exchanger. Figure III.12 shows the influence NTU can have on the cost per useful thermie and the tonnes of oil equivalent saved. It should be remembered that the cost per thermie has a different minimum level depending on whether or not heat pumps are used.

For studying a specific case, it would be worth optimizing the dimensions of the heat exchanger and the heat pumps. However. in this general study, we chose an NTU which corresponds very closely with the optimum in most cases and all the other variables were studied with an exchange such that NTU $=5$.

\subsubsection{Heat pumps}

\section{2 .3 .1 . St_udy_of_the_optimizat_tion_of_the_hea﹎_pumps}

Heat pumps are refrigerating machines connected to two sources, furnishing heat to the hot source and taking heat from the cold source. These two functions of the machine are well suited to the heating of housing units by means of geothermal hot water because they make it possible:

(i) to cool down the cold source substantially, thus extracting more calories from the geothermal water;

(ii) to heat up the hot source - in this case, the water leaving the geothermal exchanger - to the level required for use. 


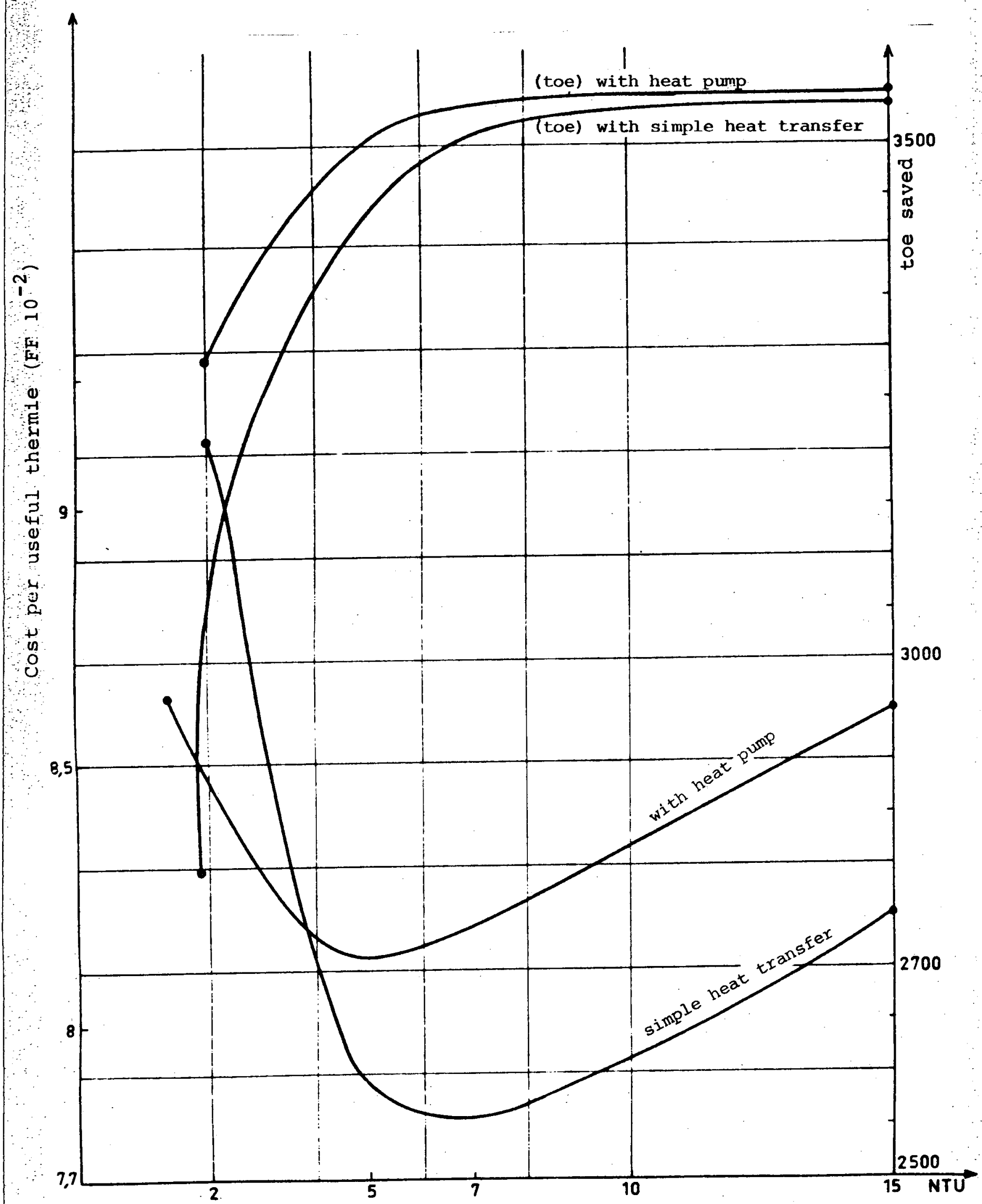

FIGURE III.12 : INFLUENCE OF THE CHOICE OF EXCHANGER (NTU) 
Extremely hot water (approximately $90^{\circ} \mathrm{C}$ ) can be obtained at the condenser outlet and premises requiring these temperatures can be heated entirely by geothermal energy combined with heat pumps. However, these high temperatures are only required for a few days in each year and the extra investment in higher capacity heat pumps would only be paid off during these few days.

The most advantageous economic solution therefore has to be sought when deciding on heat pump capacity. By way of example, we plotted changes in the cost per useful thermie for 5000 housing units heated by $90 / 70^{\circ} \mathrm{C}$ radiators as a function of the rated capacity of the heat pump (see Figures III.13 and III.14). Al1 these curves show a minimum which varies according to the flow (see Figure III.13) and the temperature of the geothermal water (see Figure III.14). 


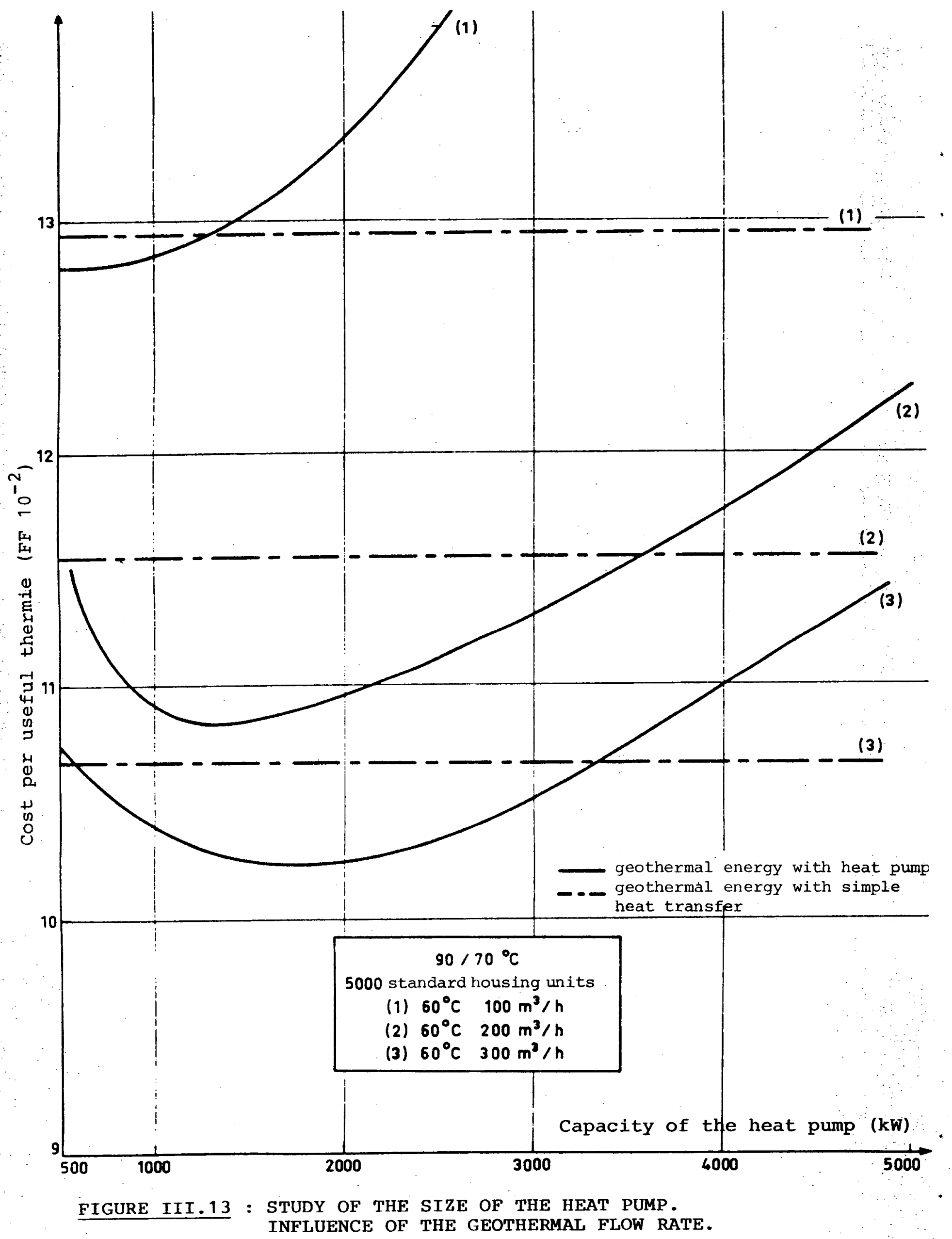




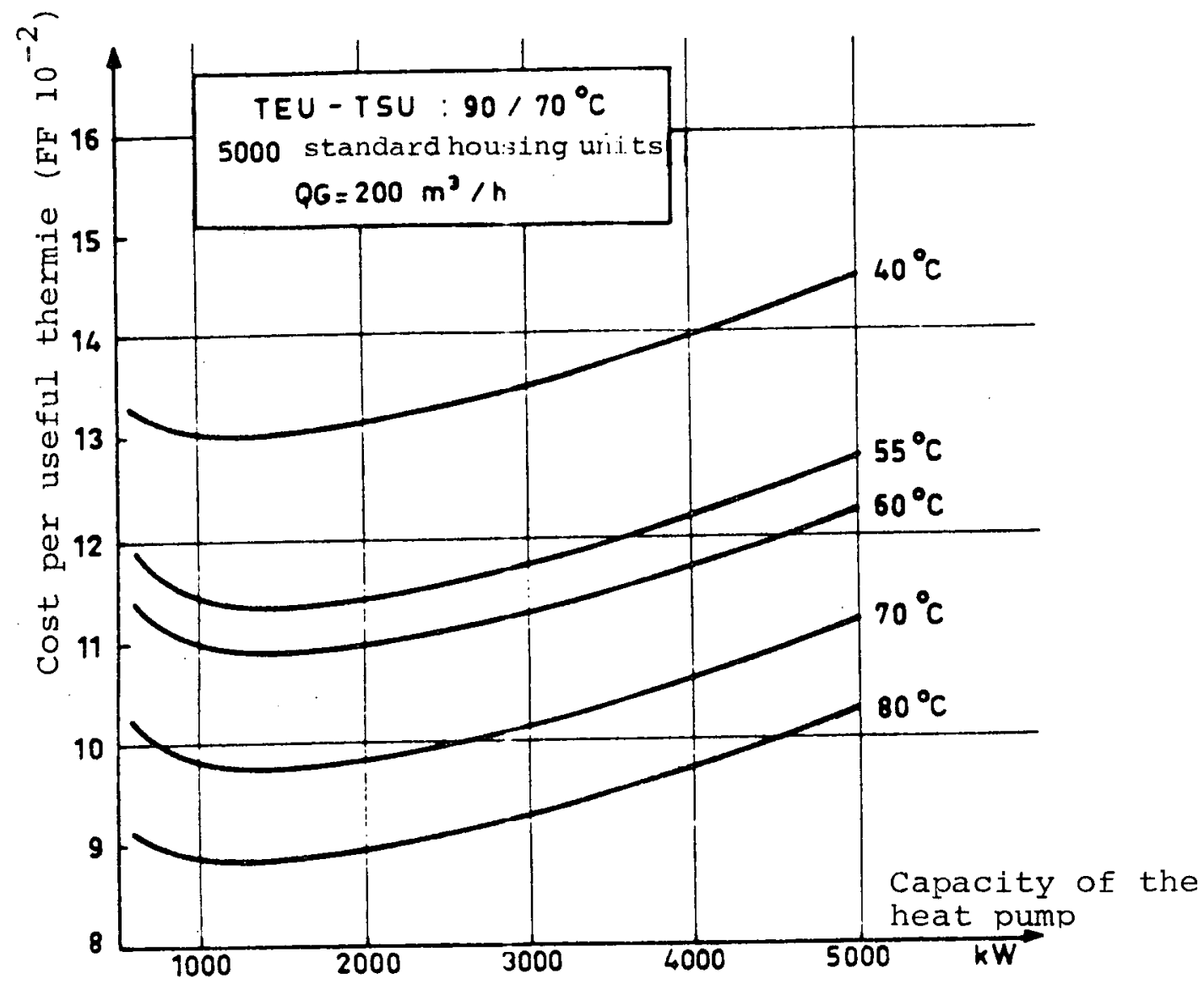

FIGURE III.14: STUDY OF THE SIZE OF THE HEAT PUMP. EFFECT OF THE TEMPERATURE OF THE GEOTHERMAL WATER.

Of course, the specific characteristics of the users, e.g. the types of interior systems (see Figure III.15) and the number of housing units, also affect the size of the heat pumps (see Figure III.16). It is even true to say that the size of the heat pump depends far more on conditions of use than on geothermal conditions. In fact, although the geothermal flow does have a slight effect on the economics of the heat pump size (see Figure III.13), the temperature of the geothermal water has only a very slight bearing on the choice of the electrical noting of heat pumps. However, the example chosen is for hightemperature radiators, the effect of the temperature of the geothermal water being more important if housing units are fitted with low-temperature systems. 
The factor governing the size of the heat pump is the number of housing units or the annual heat consumption of all the "consumers". In Figure III.16. we showed how the capacity of the heat pump affects cost per thermie for various numbers of housing units.

The percentages are the proportion of the maximum heat taken off by the "consumer" accounted for by the heat at the heat pump condenser.

It can be seen that if the number of housing units exceeds 2500 , the capacity of a heat pump need only represents some 208 of capacity for each temperature drop of $7^{\circ} \mathrm{C}$ outside for the discounted cost per thermie to be less than with simple heat transfer. On the other hand, if the number of housing units is low (less than 2 300), simple heat transfer is more economic than the use of a heat pump, even if it represents only 408 of capacity. 


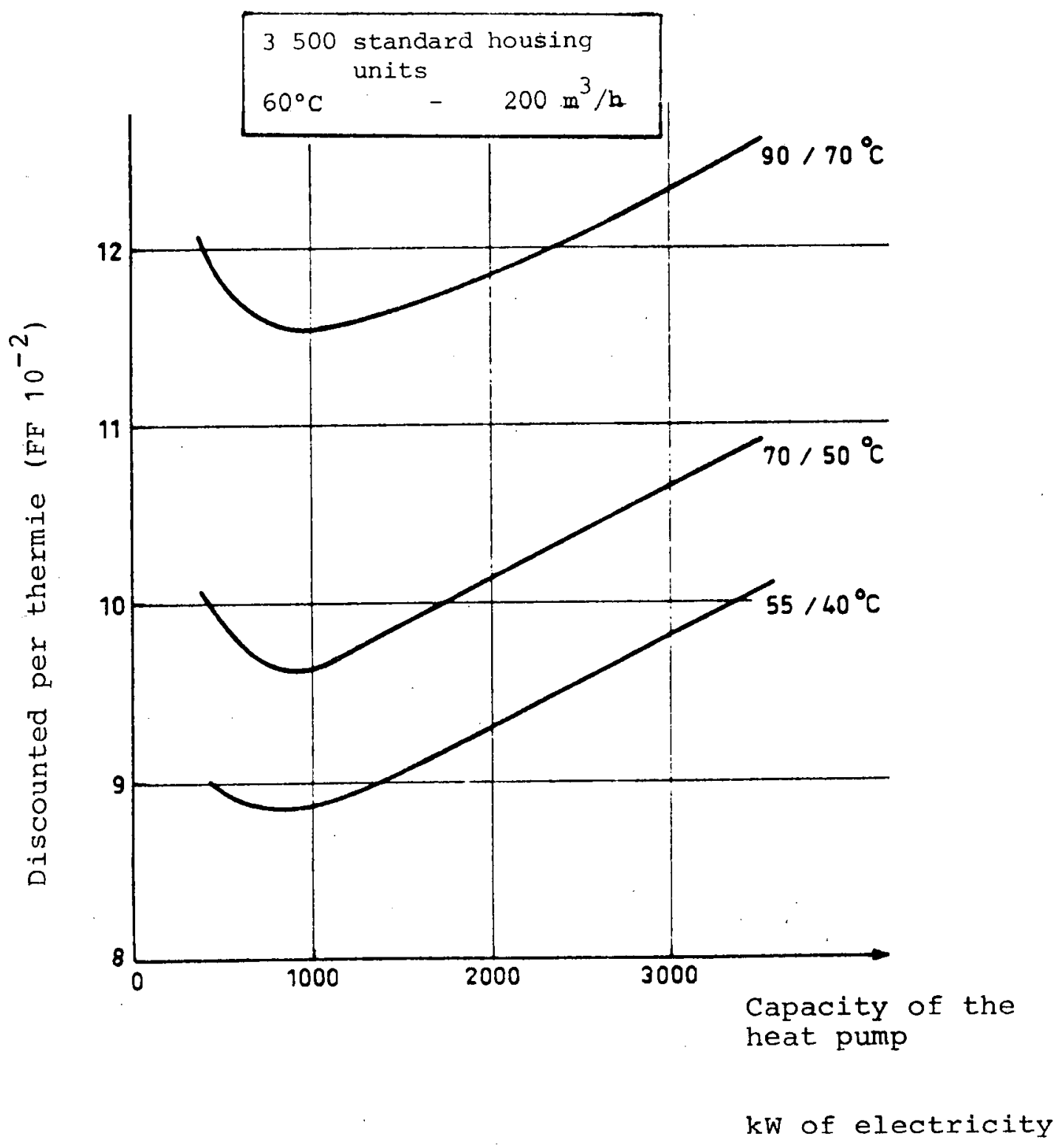

FIGURE III.15 : STUDY OF HEAT PUMP SIZE. INFLUENCE OF THE TEMPERATURE OF THE HEATING SYSTEM. 


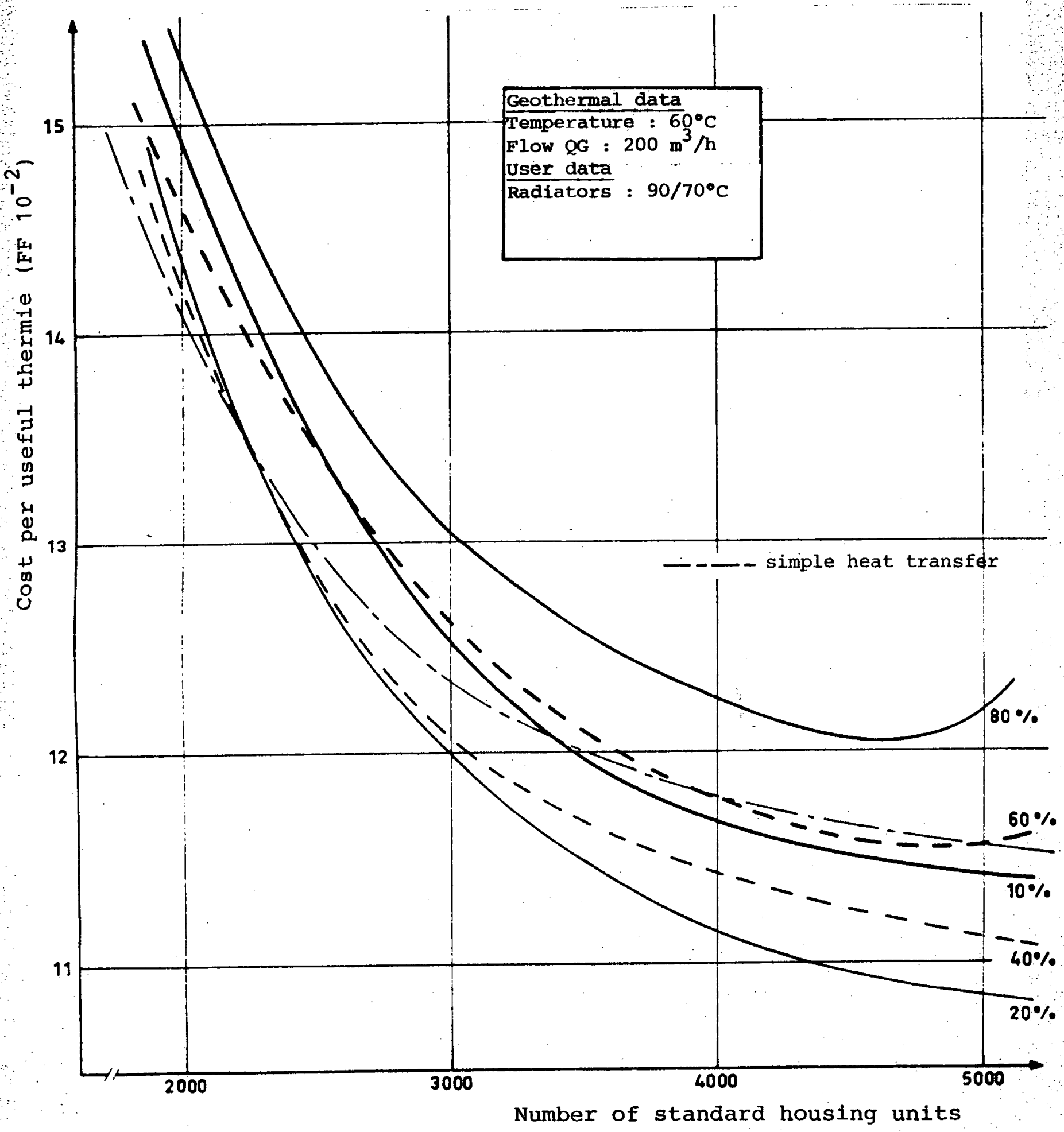

FIGURE III.16 : INFLUENCE OF THE NUMBER OF HOUSING UNITS ON THE
SIZE OF THE HEAT PUMPS 
These curves were plotted for housing units fitted with radiators whose inlet water temperature is $90^{\circ} \mathrm{C}$ when the outside temperature is $-7{ }^{\circ} \mathrm{C}$ and whose outlet temperature is $70^{\circ} \mathrm{C}$. If the same number of housing units had heating units designed for a lower temperature eg. $70 / 50^{\circ} \mathrm{C}$ or $55 / 40^{\circ} \mathrm{C}$ this would not alter the size of the heat pump very much (see Figure III.15).

\subsubsection{2. - Infl_uence_of_the_heat_pump}

The influence of the heat pump in the energy balance of a geothermal heating project was discussed in paragraph III. 1.

A heat pump always increases geothermal efficiency; the greater the pump's capacity the greater the increase. The same applies to savings in primary energy (see Figure III.17). However the advantage of fitting a geothermal heating installation with heat pumps is usually evaluated on the basis of economic criteria like the cost per useful thermie, rather than energy criteria like geothermal efficiency or the amount of primary energy saved. 


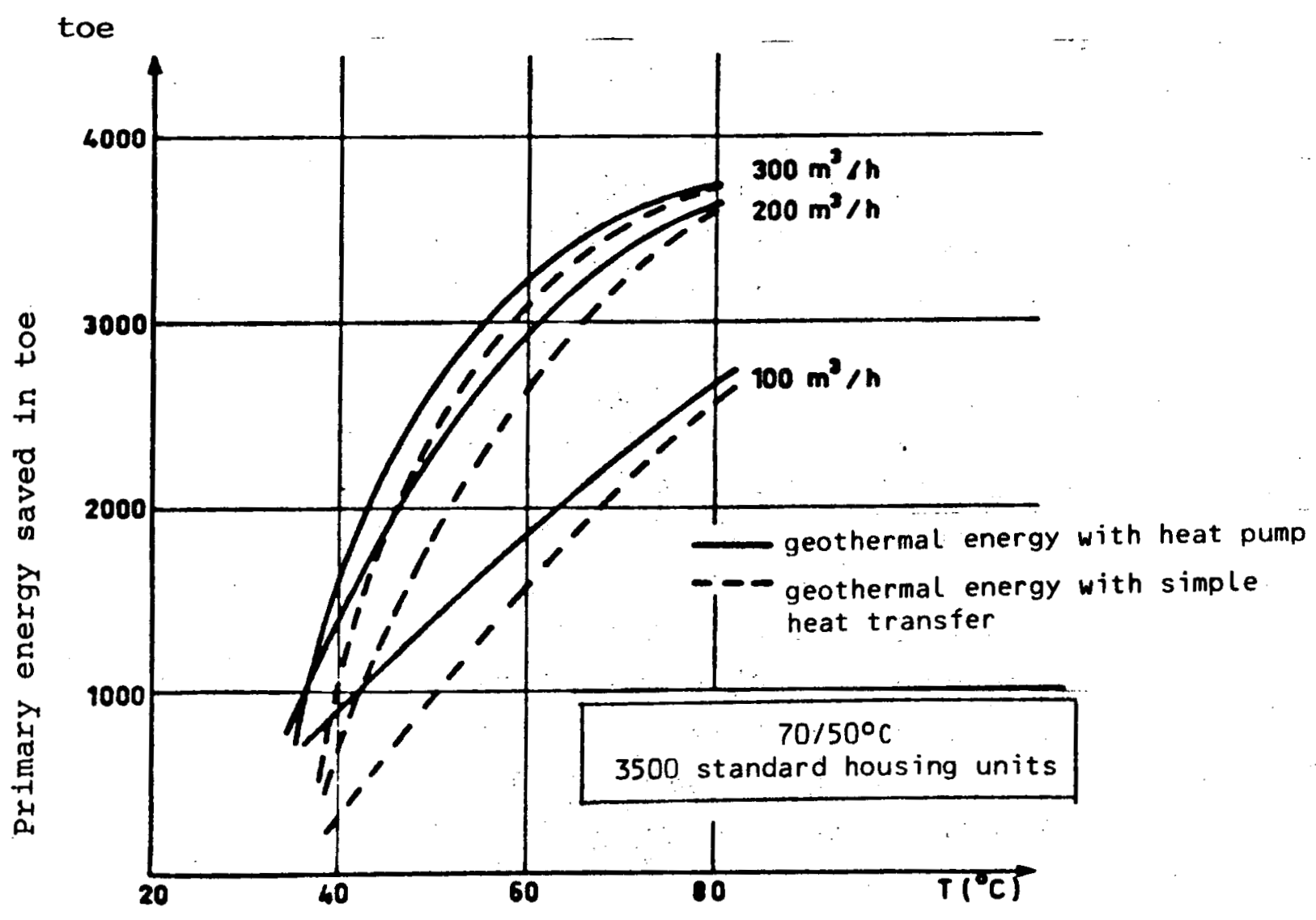

FIGURE III.17 : INFLUENCE OF THE HEAT PUMP ON SAVAINGS OF PRIMARY ENERGY AS A FUNCTION OF GEOTHERMAL TEMPERATURE 
Thus, considering the investment cost of the heat pump and its electricity consumption, the use of heat pumps is only justified in certain circumstances. For example, if the geothermal flow is $200 \mathrm{~m}^{3} / \mathrm{h}$ there is no economic advantage in using a heat pump if the water is at a temperature of $80^{\circ} \mathrm{C}$; if the water is at $60^{\circ} \mathrm{C}$ it may be justified if there are sufficient housing units and if the water is at $40^{\circ} \mathrm{C}$ (see Figure III.18) it is always economic with low temperature radiators $\left(70 / 50^{\circ} \mathrm{C}\right)$.

When the temperature in the heating system drops, the use of heat pumps is not so beneficial as geothermal water does not always needs to be re-heated (see Figure III.19).

On the other hand, heat pumps are of substantial economic benefit in old buildings fitted with conventional radiators at $90 / 70^{\circ} \mathrm{C}$ (see Figure III.20).

3.3. INFLUENCE OF CONDITIONS OF USE

The conditions imposed by users or consumers of heat are as important as the nature of the geothermal resource. The choice of which housing complexes have to be heated is determined by:

(i) the climatic region, the number of housing units and the type of units, and thus the annual energy requirements;

(ii) the heating system setting curves.

Actual requirements are calculated from the first two parameters. Paragraph II.2 explained the specifications adopted for the purposes of this study. The influence of these parameters is covered by OET in another report. 


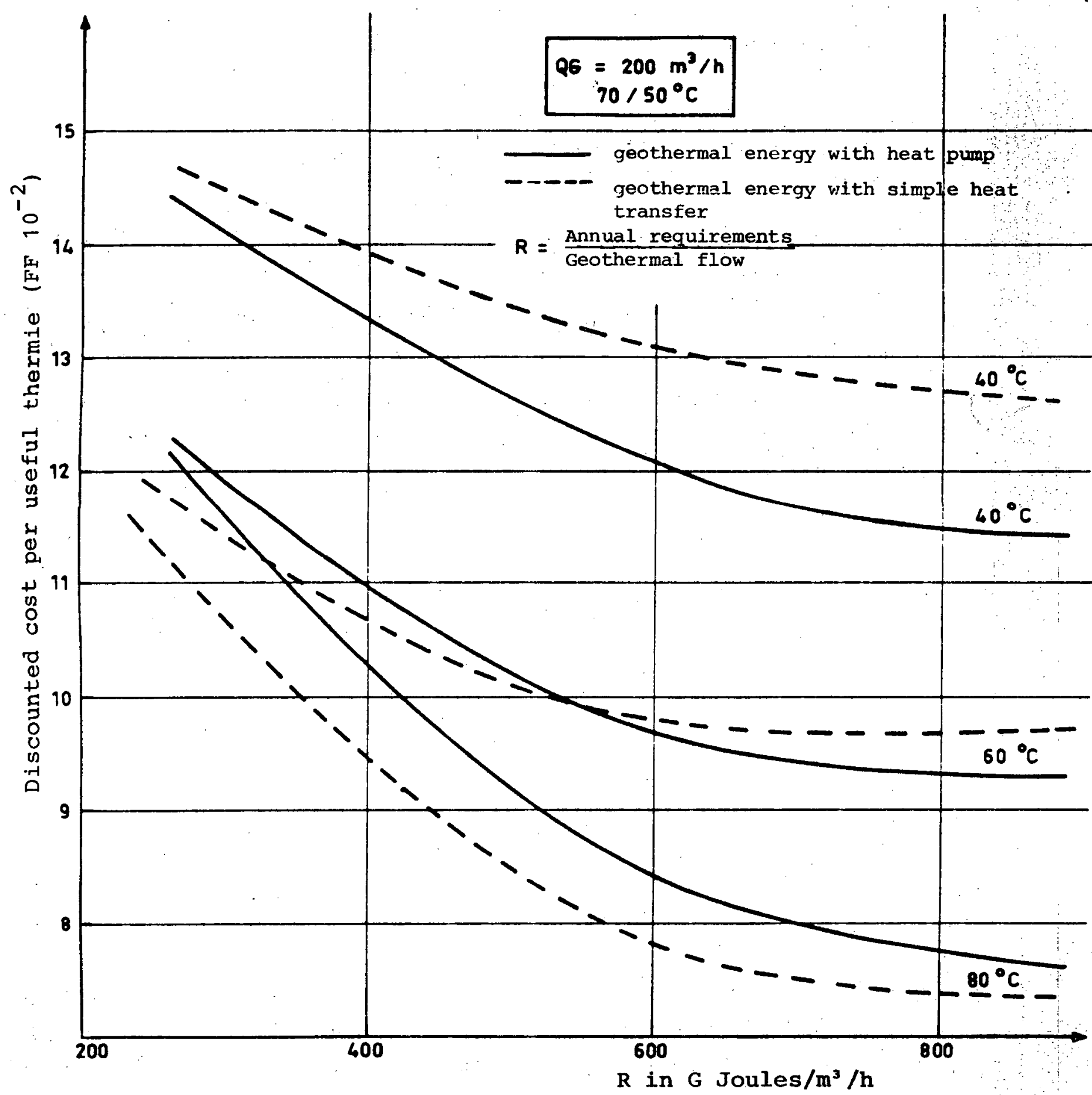

FIGURE III.18 : INFLUENCE OF THE HEAT PUMP ON THE COST PER USEFUL THERMIE $\left(90 / 70^{\circ} \mathrm{C}\right.$ RADIATORS) 


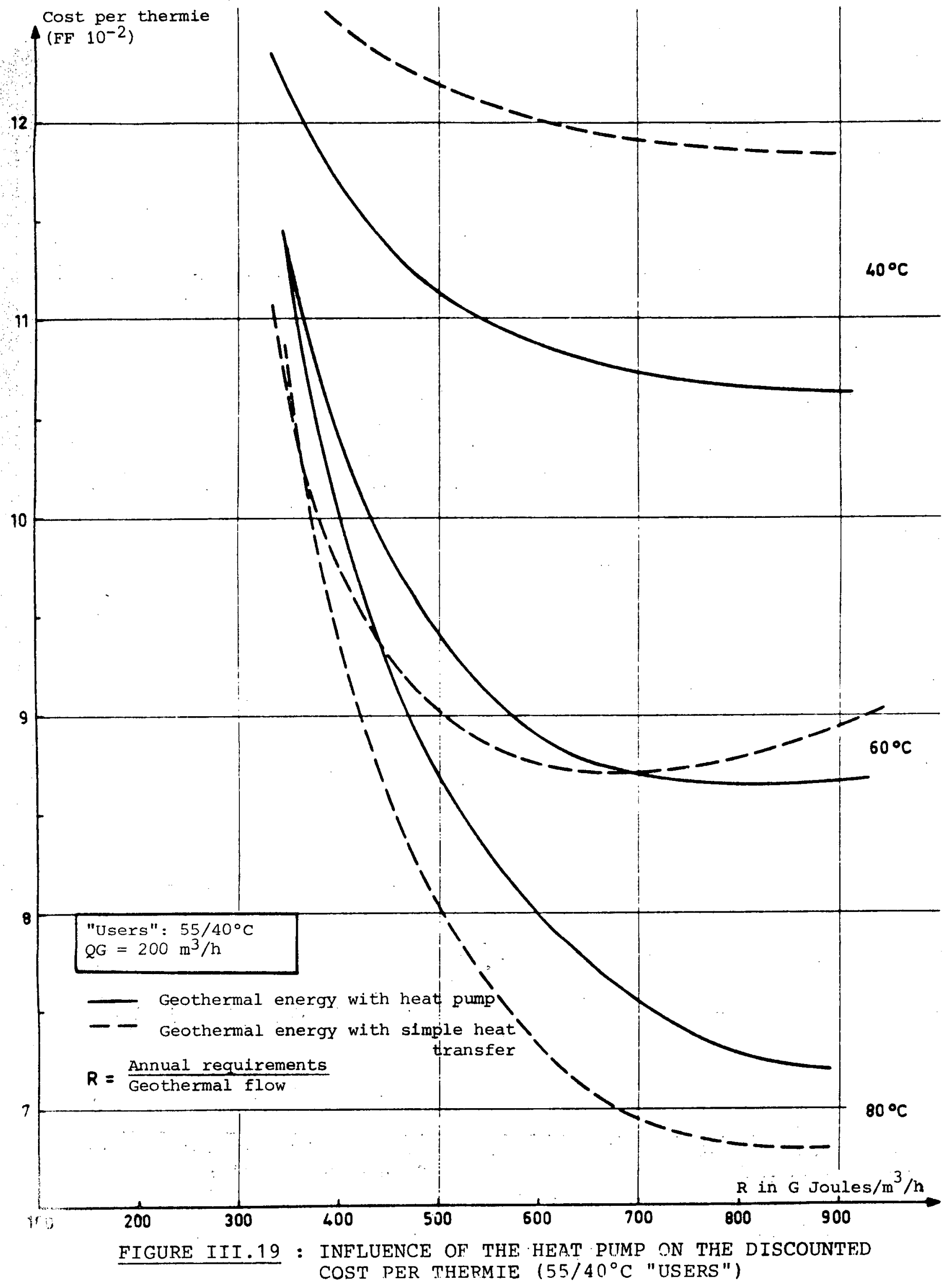




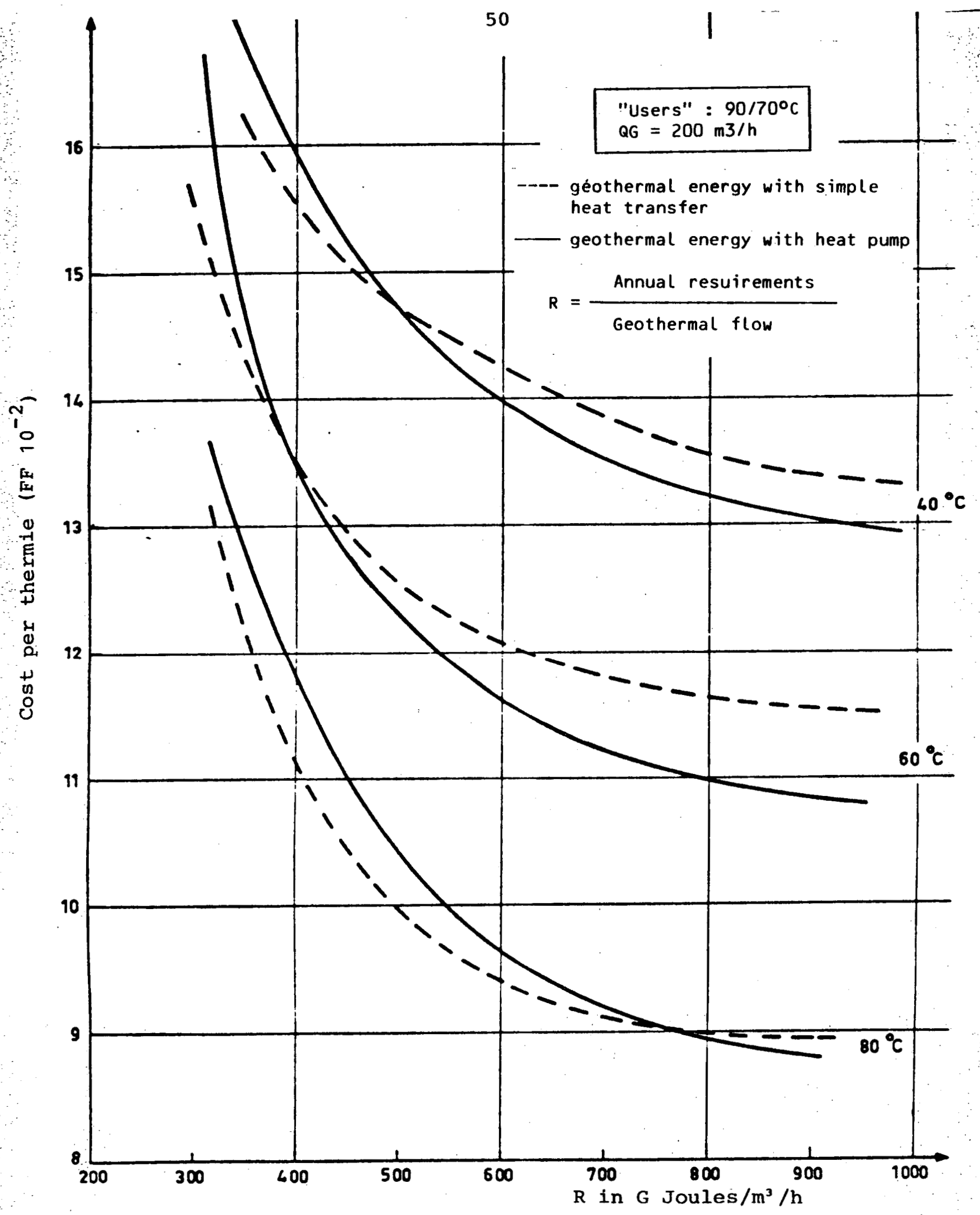

FIGURE III. 20 


\subsubsection{Climatic data and free heat}

The meteorological data used was obtained from orly for the year 1976-1977.

The amount of sun and free heat differs according to the type of housing or flats their exposure, etc.

We allowed for free heat when calculating the heating requirements for housing units as follows: between $7 \mathrm{am}$ and $6 \mathrm{pm}$, the outside temperature was increased by $\Delta T^{\circ} \mathrm{C}$ and between $10 \mathrm{am}$ and $4 \mathrm{pm}$ by $\Delta \mathrm{TX}$. Thus, the free heat is greater in the middle of the day when there is more sunshine and housing units are more likely to be occupied. Heating requirements for the same number of housing units vary according to the temperature differences $\Delta \mathrm{T}$ and $\Delta \mathrm{TX}$ selected. The correspondence between heating requirements and the number of housing units is shown in Figure III.21 for different temperature differences resulting from the supply of free heat.

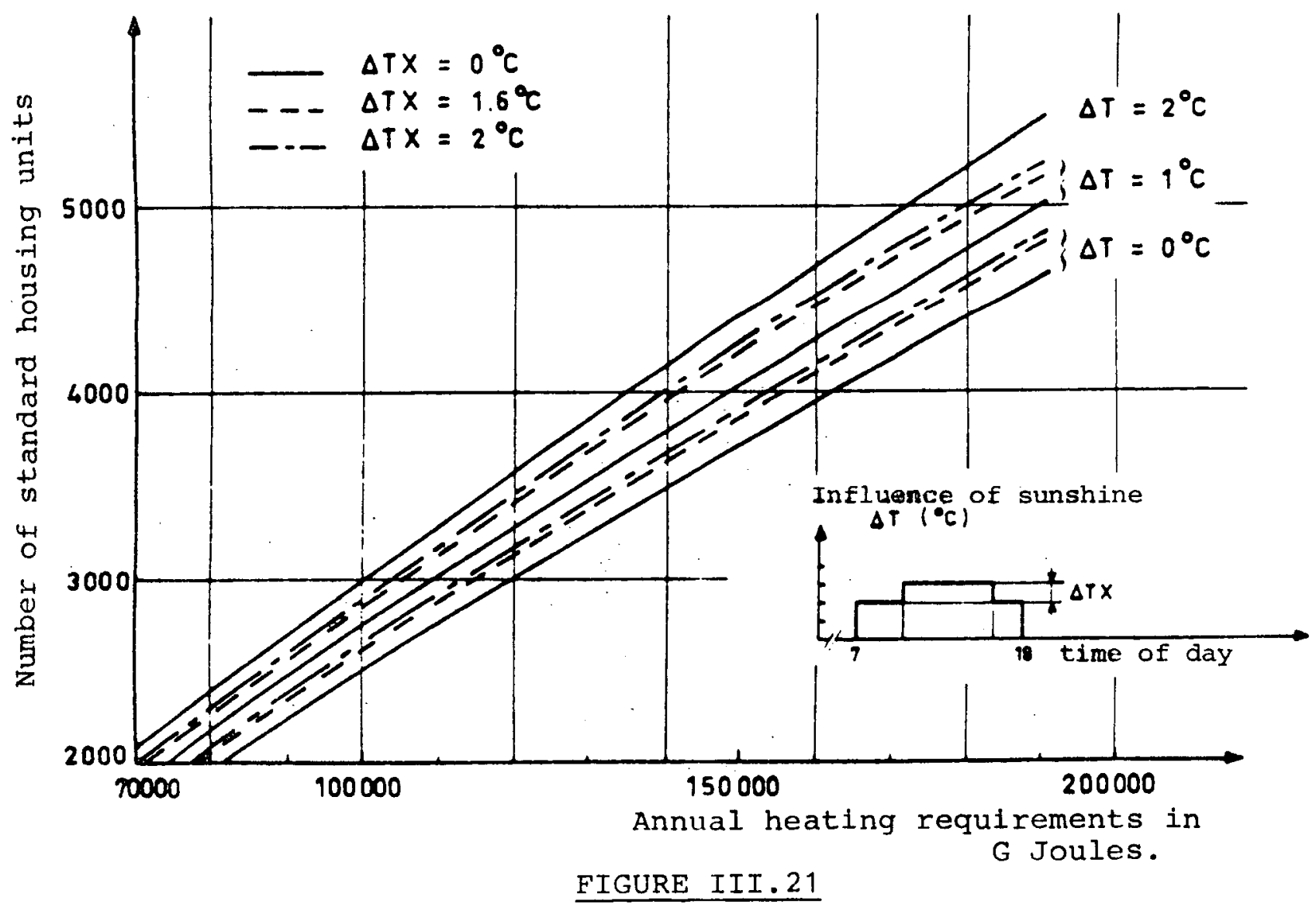


Sunshine may satisfy a substantial proportion of requirements. With the values taken for the study as a whole, it covered nearly 12.5 of requirements (see Figure III.22). To give some indication, Figure III.23 shows the number of housing units this represents.

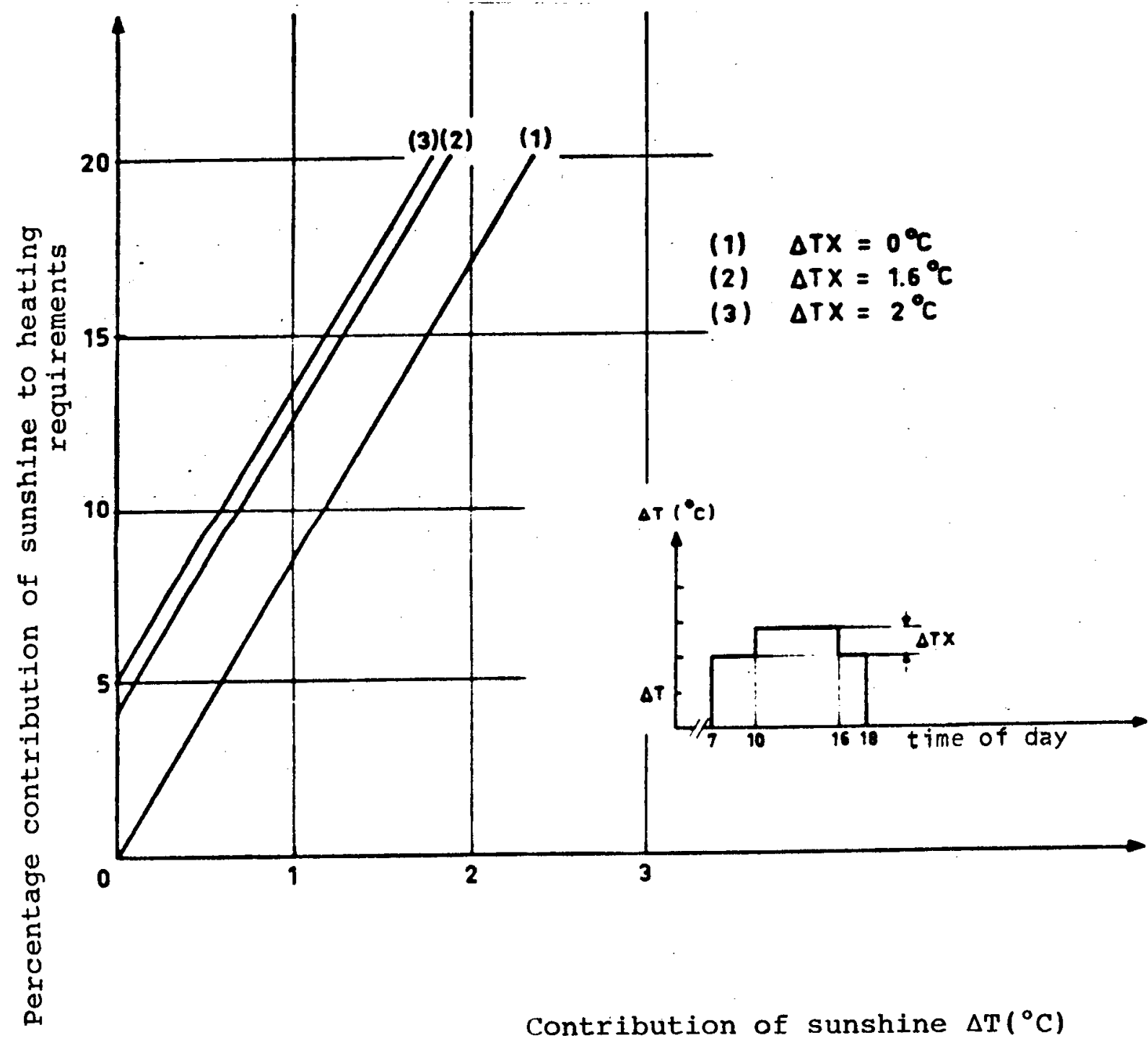

FIGURE III. 22 


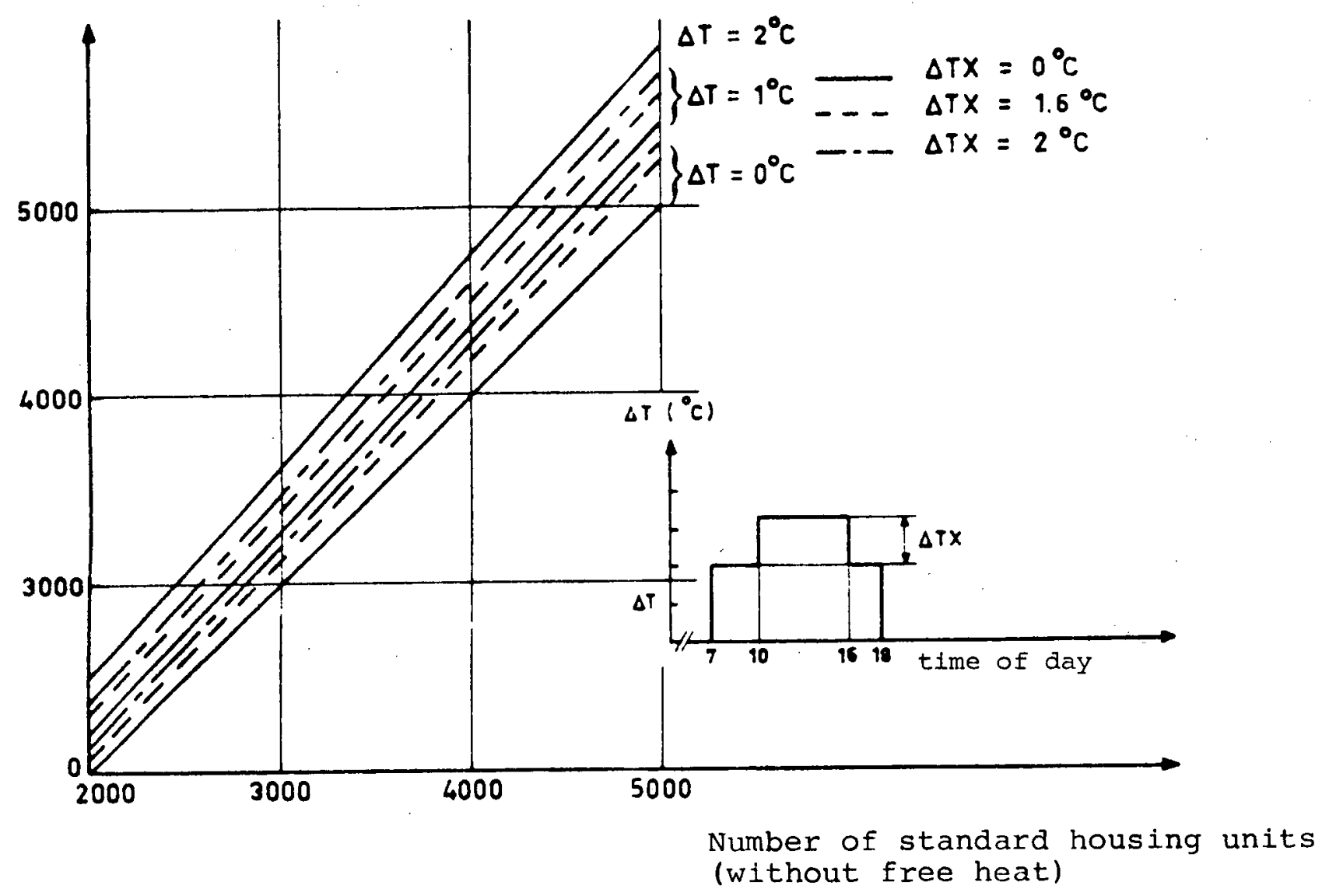

FIGURE III. 23

3.3.2. Influence of type of housing on heating requirements

The heating requirements are equivalent to the heat losses from the dwellings and are therefore proportional to the volume $V$ of the dwellings, their insulation coefficient of $G$ and the difference between the outside temperature and the ambient temperature indoors. New buildings are generally better insulated $\left(G<1 \mathrm{~W} / \mathrm{m}^{3}{ }^{\circ} \mathrm{C}\right)$ than old buildings $\left(\mathrm{G} \neq 1.5 \mathrm{~W} / \mathrm{m}^{3}{ }^{\circ} \mathrm{C}\right)$. Depending on the type of housing to be heated by geothermal energy, requirements for 3500 housing units may vary from $95000 \mathrm{G}$ joules to $177000 \mathrm{G}$ joules, a variation of some 468 (see Figure III. 24). 
54

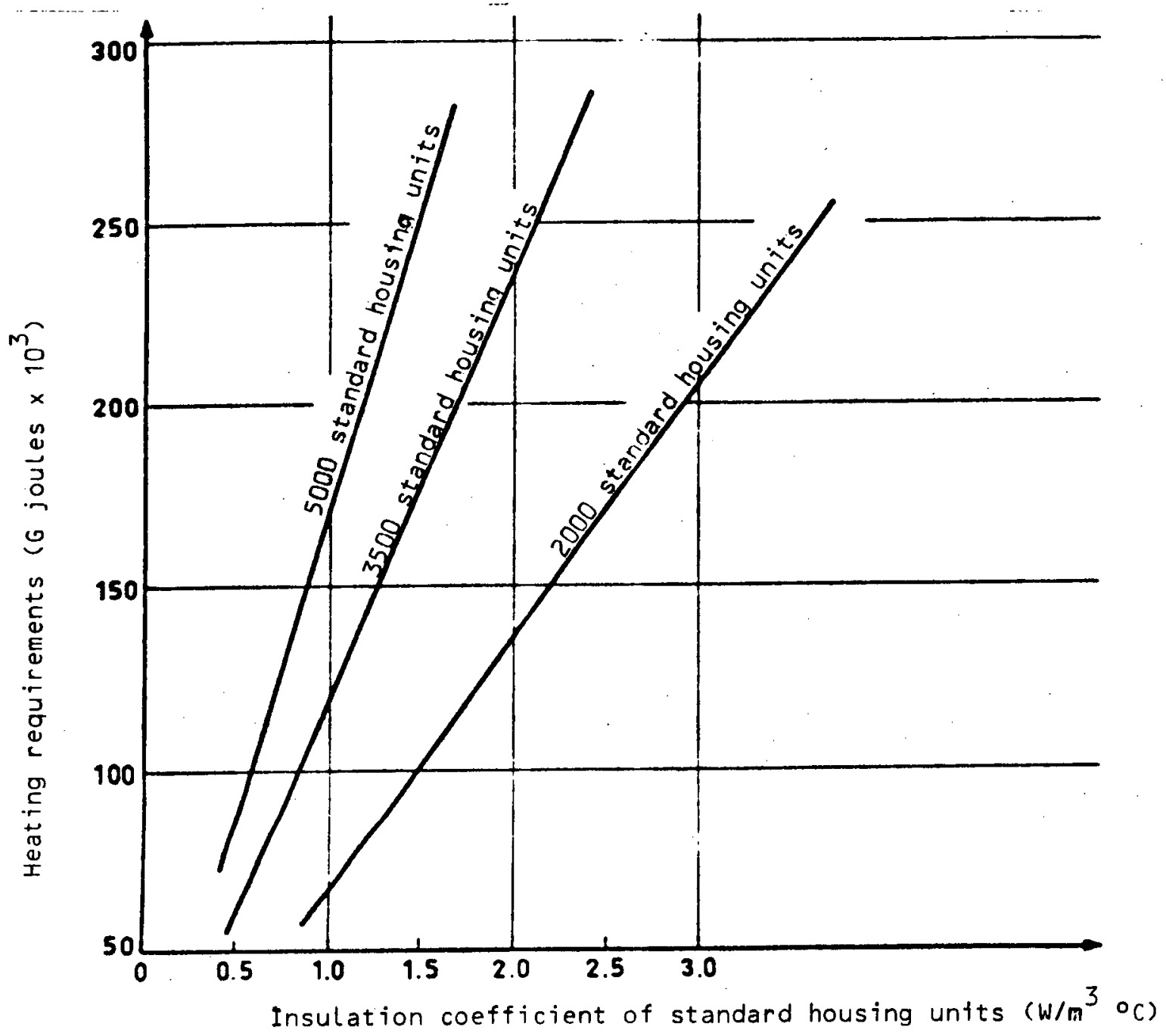

FIGURE III.24: INFLUENCE OF THE INSULATION COEFFICIENT OF BUILDINGS ON HEATING REQUIREMENTS

In all cases for which nomograms have been plotted, an average insulation coefficient of $\mathrm{G}=1.05 \mathrm{~W} / \mathrm{m}^{3}{ }^{\circ} \mathrm{C}$ was assumed. Figure III. 25 shows the effect of this on the cost per thermic.

In buildings are not very well insulated, annual heating requirements are higher, a fact which makes geothermal energy more economic. 


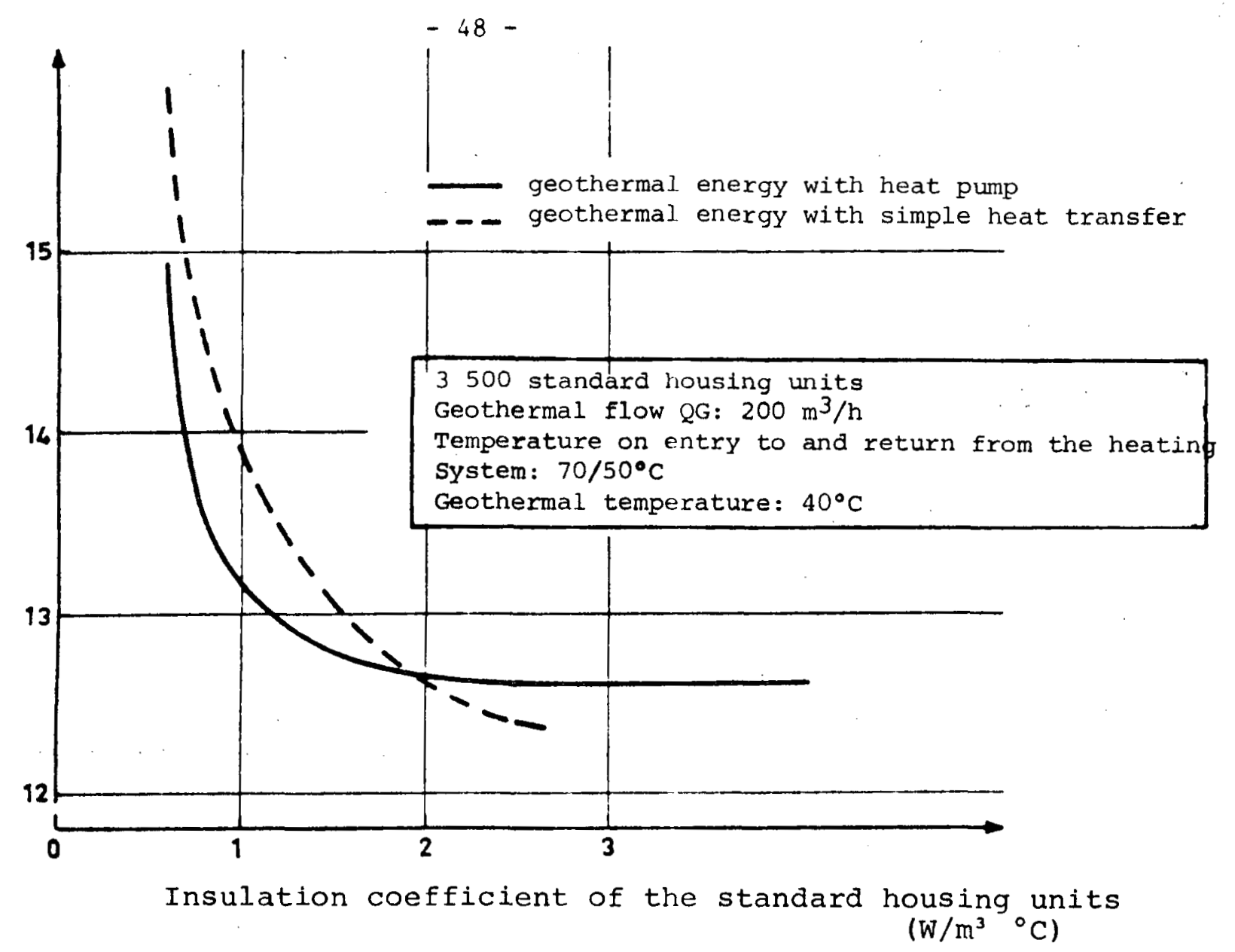

FIGURE III.25: INFLUENCE OF THE INSULATION COEFFICIENT OF BUILDINGS ON COST PER USEFUL THERMIE.

\subsubsection{Influence of the temperature of heating systems}

The heat level of indoor systems is extremely important in any geothermal heating project. If it is low, it may be sufficient to use geothermal energy with simple heat transfer; otherwise heat pumps and a supplementary energy source have to be added.

The lower the geothermal temperature, the more it affects geothermal efficiency and the cost per thermie.

For example, geothermal efficiency for 3500 housing units and with water at $40^{\circ} \mathrm{C}$ is 67.58 for housing units fitted with underfloor heating and 328 for units fitted with $90 / 70^{\circ} \mathrm{C}$ radiators. 
If the geothermal water has a temperature of $80^{\circ} \mathrm{C}$, the operating temperature of the heating units is less important : efficiency is 928 with $55 / 40^{\circ} \mathrm{C}$ underfloor heating and 848 with $90 / 70^{\circ} \mathrm{C}$ radiators (see Figure III.26).

Temperature has an appreciable effect on savings of primary energy, irrespective of the temperature of the geothermal water (see Figure III.27).

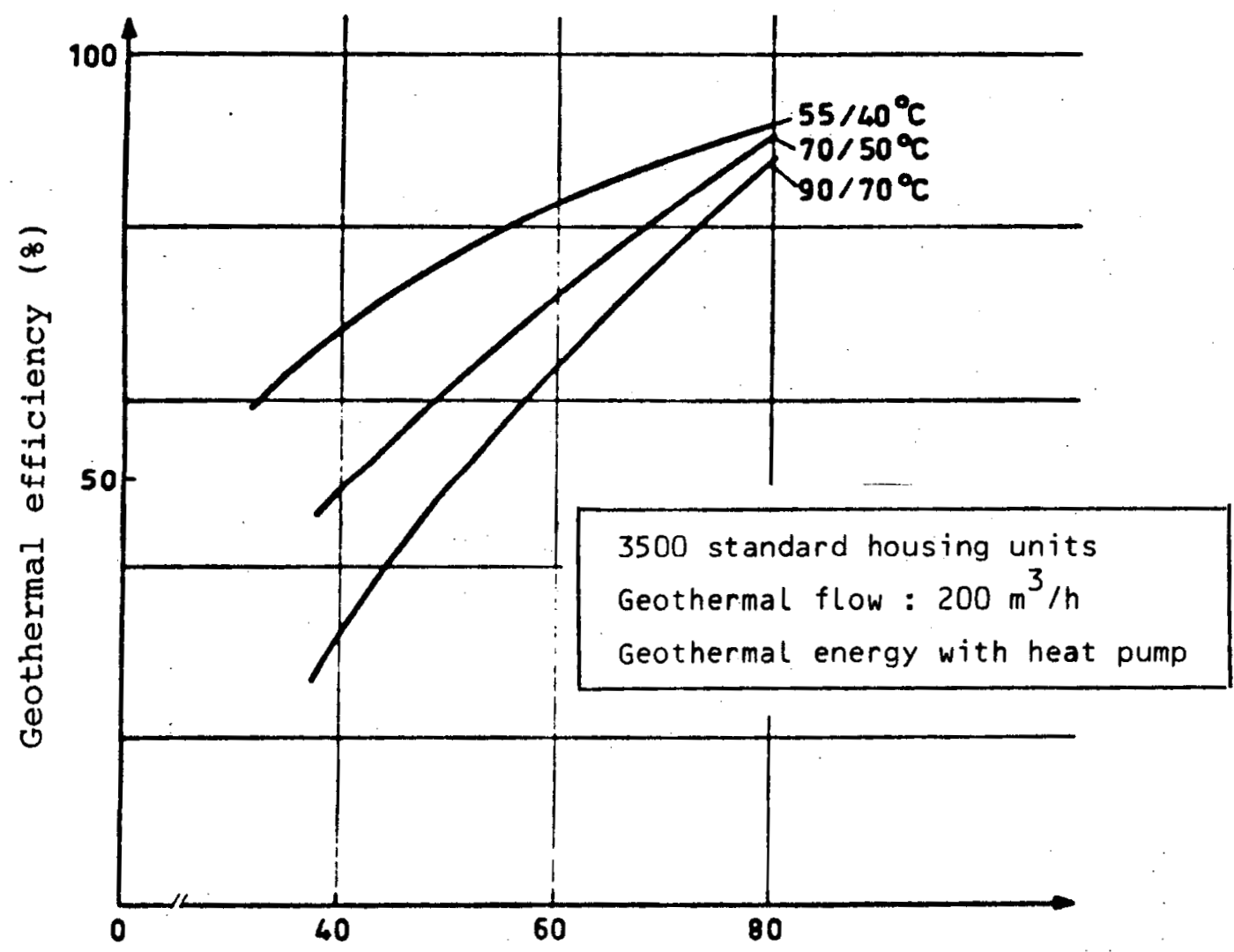

Geothermal temperature $\left({ }^{\circ} \mathrm{C}\right)$

FIGURE III.26 : INFLUENCE OF GEOTHERMAL TEMPERATURE ON GEOTHERMAL EFFICIENCY FOR VARIOUS TEMPERATURES OF HEATING SYSTEM. 
It is important to know the straight lines which show the settings of the heating units when deciding on a geothermal heating project since, even with the same temperature and flow conditions $\left(60^{\circ} \mathrm{C}\right.$ and $200 \mathrm{~m}^{3} / \mathrm{h}$, for example), the cost per thermie for 3500 housing units varies by more than 208 depending on whether they are fitted with radiators or underfloor heating (see Figure III.28). Incldentally, these results were obtained for a system fitted with a heat pump, which reduces the importance of the setting temperatures.

In fact, installing $90 / 70^{\circ}$ radiators instead of $55 / 40^{\circ} \mathrm{C}$ underfloor heating reduces geothermal efficlency by some $27 \%$ geothermal energy if simple heat transfer is used and some $17 \%$ if heat pumps are added (see Figure III.29). A heat pump improves geothermal efficiency, chiefly because - by cooling the water which leaves the heating system - it makes it possible to

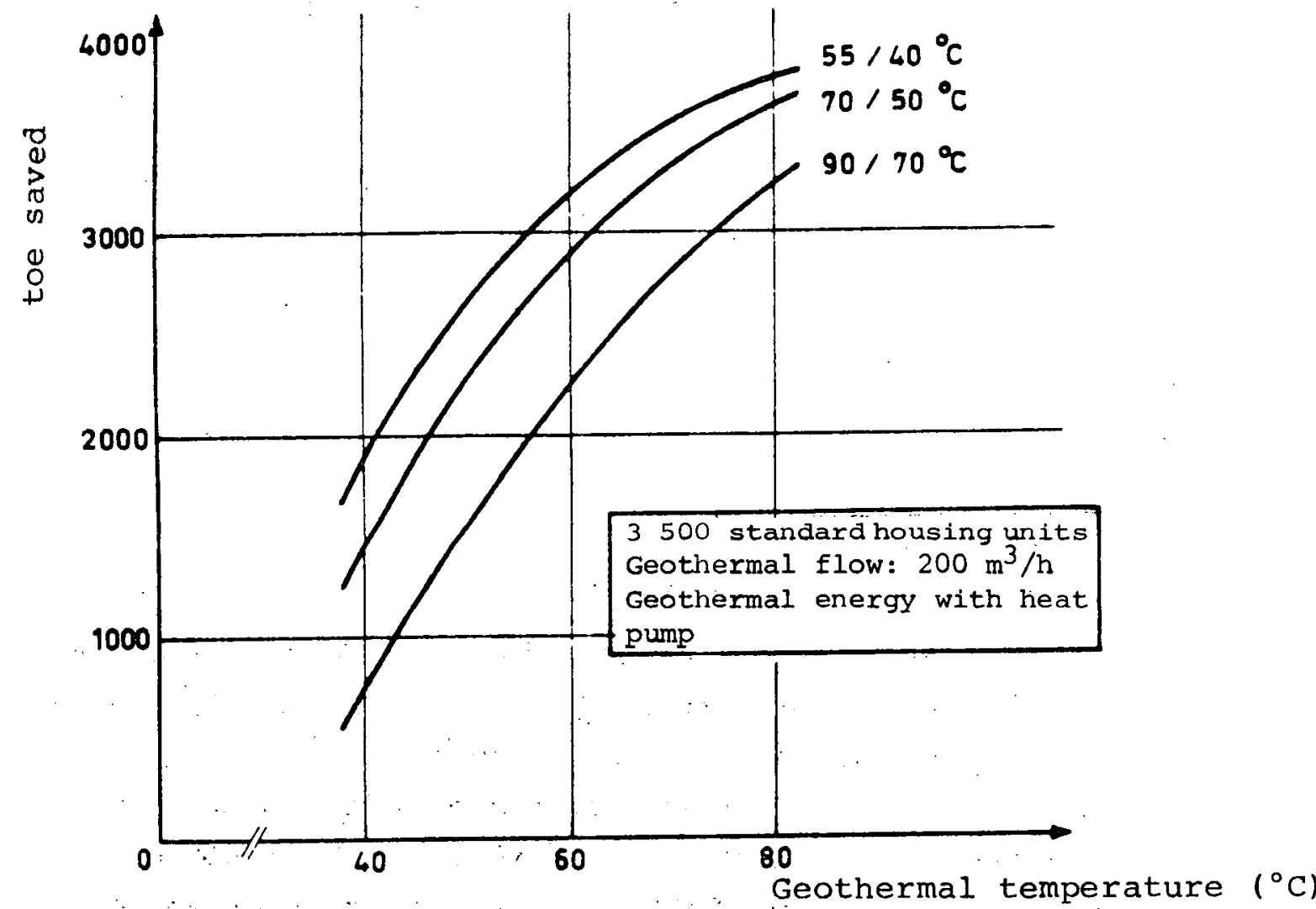

FIGURE III.27: INFLUENCE OF GEOTHERMAL TEMPERATURE ON TONNES OF OIL EQUIVALENT SAVED FOR VARIOUS HEATING SYSTEM TEMPERATURES. 


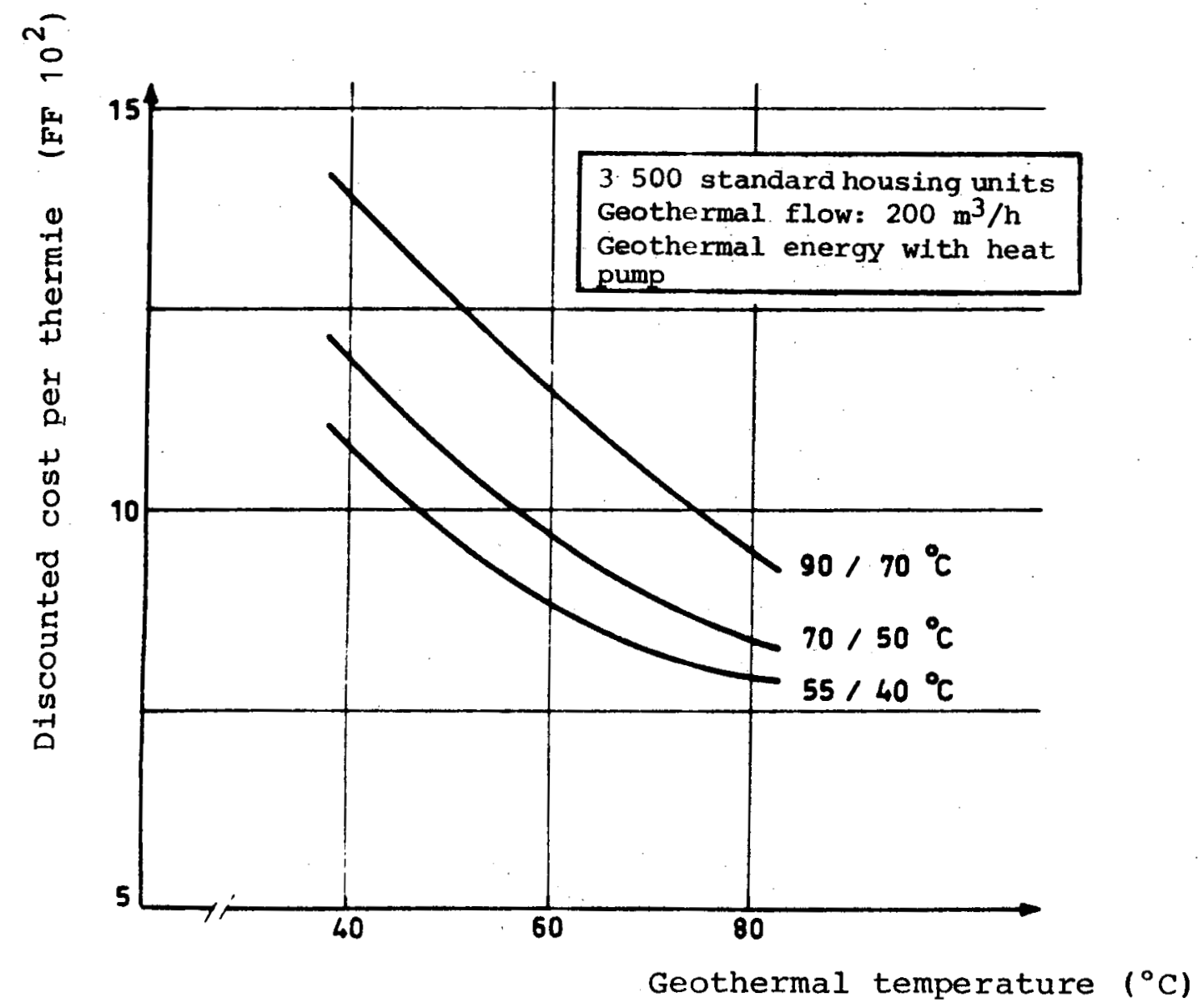

FIGURE III.28 : INFLUENCE OF GEOTHERMAL TEMPERATURE ON THE DISCOUNTED COST PER THERMIE FOR VARIOUS HEATING SYSTEM TEMPERATURES.

achieve fuller use of the geothermal resource. We used the results obtained for the three types of heating system studied to plot changes in geothermal efficiency according to the temperature at which the water leaves the heating system, with and without heat pumps (see Figure III.30). The heat pump increases geothermal efficiency even more in cases where water leaves the heating units at high temperatures (it is $48 \%$ instead of 288 for a TS temperature of $70^{\circ} \mathrm{C}$ and 628 instead of 468 for a TS temperature of $40^{\circ} \mathrm{C}$ ). 
However, in spite of the heat pump, the geothermal efficiency of heating housing units with $90 / 70^{\circ} \mathrm{C}$ radiators is lower than if these units had $55 / 40^{\circ} \mathrm{C}$ underfloor heating.

\subsection{ECONOMIC VARIABLES}

\subsubsection{Influence of the cost of materials}

Investment accounts for a large proportion of the cost of a geothermal heating project; some $50 \%$ in heating 3500 housing units with water at $60^{\circ} \mathrm{C}$ (see Figure III.31).

The main investment is the cast of sinking the boreholes. We have plotted how the cost of the boreholes affects the discount cost per useful thermie (Figure III.32) for a geothermal installation with heat pump. Under the same conditions $(3500$ units fitted with $70 / 50^{\circ} \mathrm{C}$ radiators), the cost of the heat pump has only a slight effect on the discounted cost per thermie. Even if the price of the heat pump were twice that used for the calculations, the cost per thermie would only increase from 8.3 to 8.65 centimes for geothermal water at $80^{\circ} \mathrm{C}$ or from 9.90 to 10.2 centimes for water at $60^{\circ} \mathrm{C}$ (see Figure III.33). 


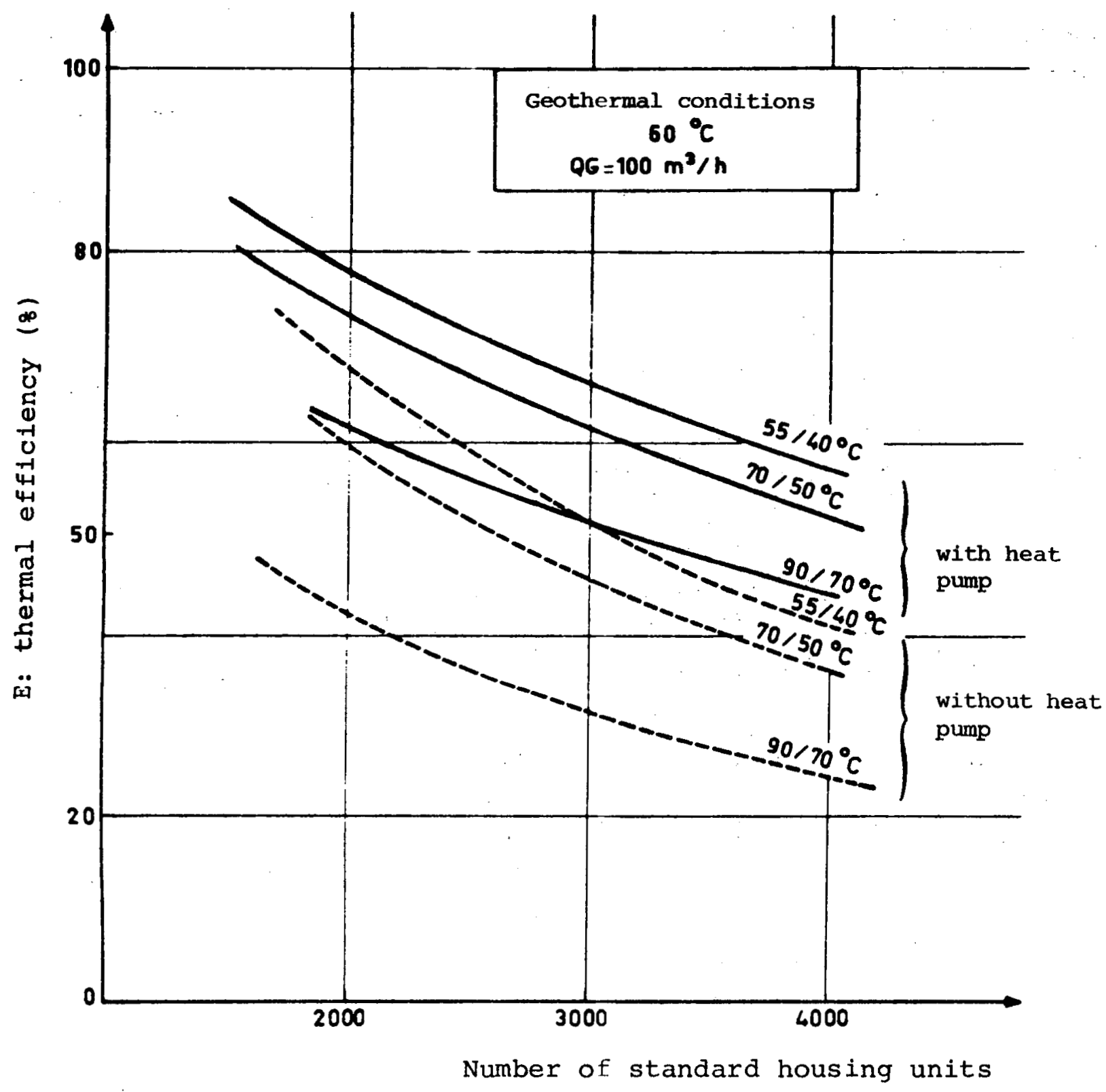

FIGURE III.29 : INFLUENCE OF THE INDOOR SYSTEMS ON GEOTHERMAL EFFICIENCY 


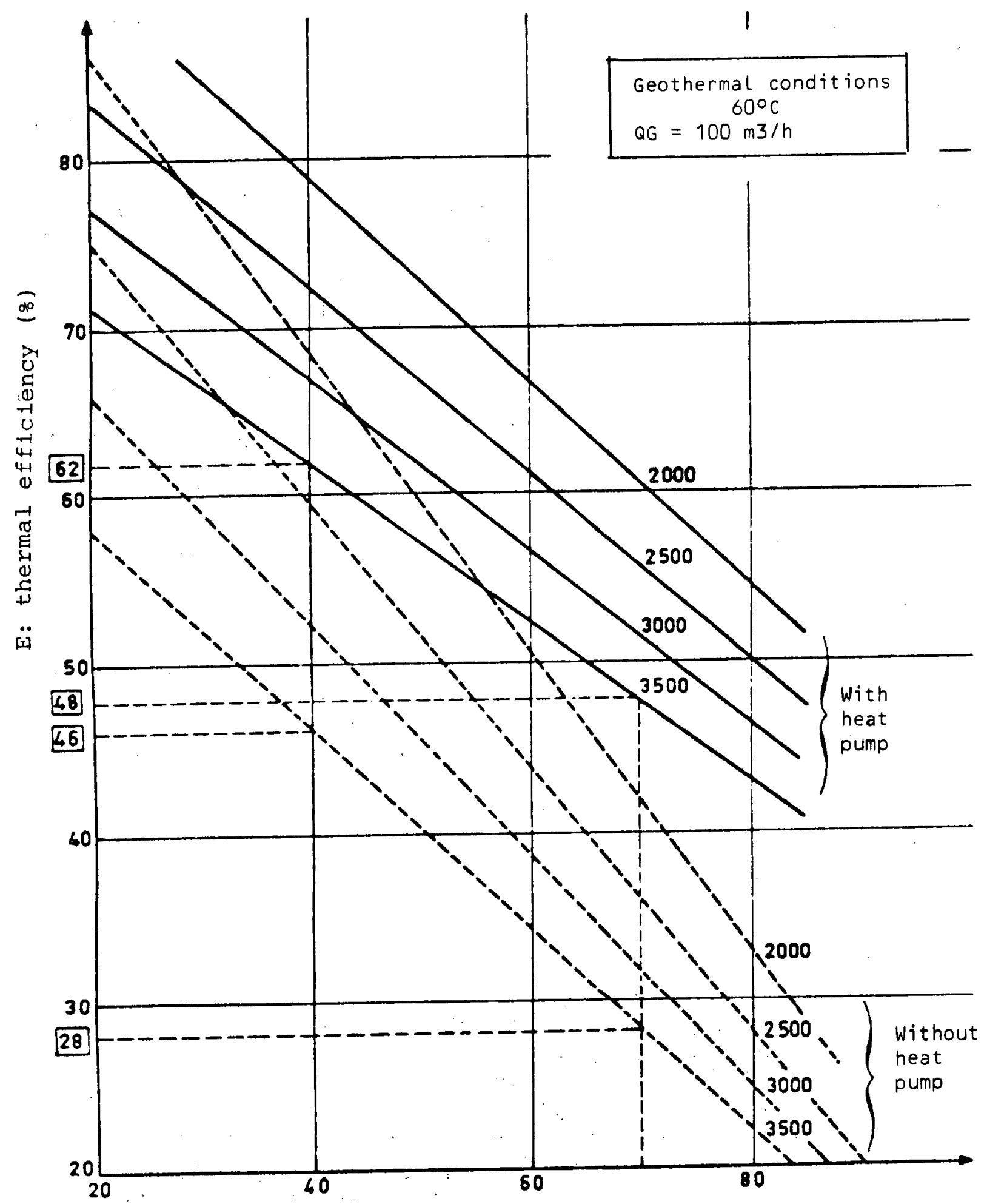

outlet temperature from the heating system $\left(0^{\circ} \mathrm{C}\right)$

FIGURE III. 30 : INFLUENCE OF. THE OUTLET TEMPERATURE FROM THE HEATING SYSTEM ON THE PROPORTION OF GEOTHERMAL ENERGY USED TO SUPPLY HEAT. 


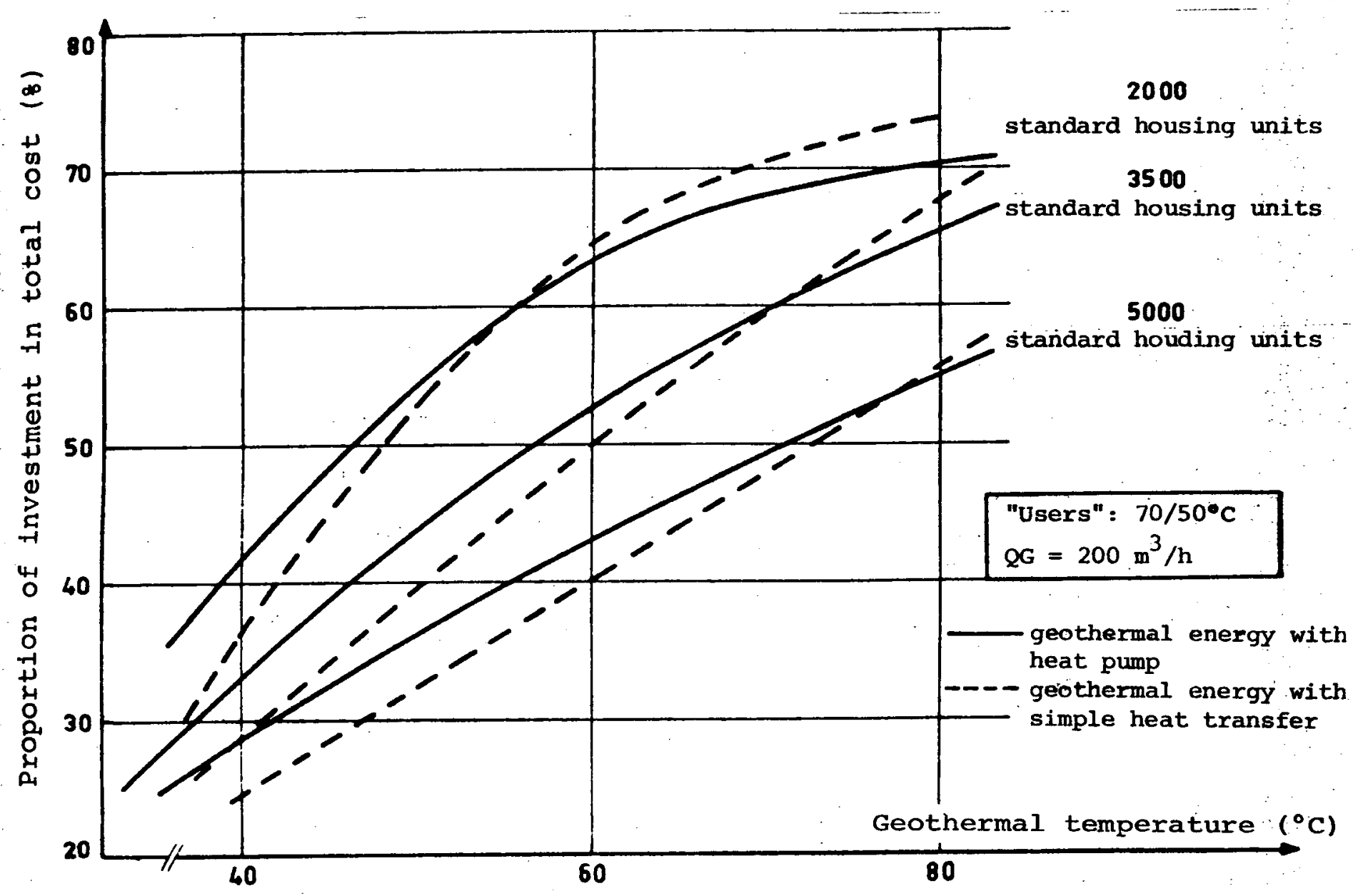

FIGURE III.31 : PROPORTION OF INVESTMENT IN TOTAL COST

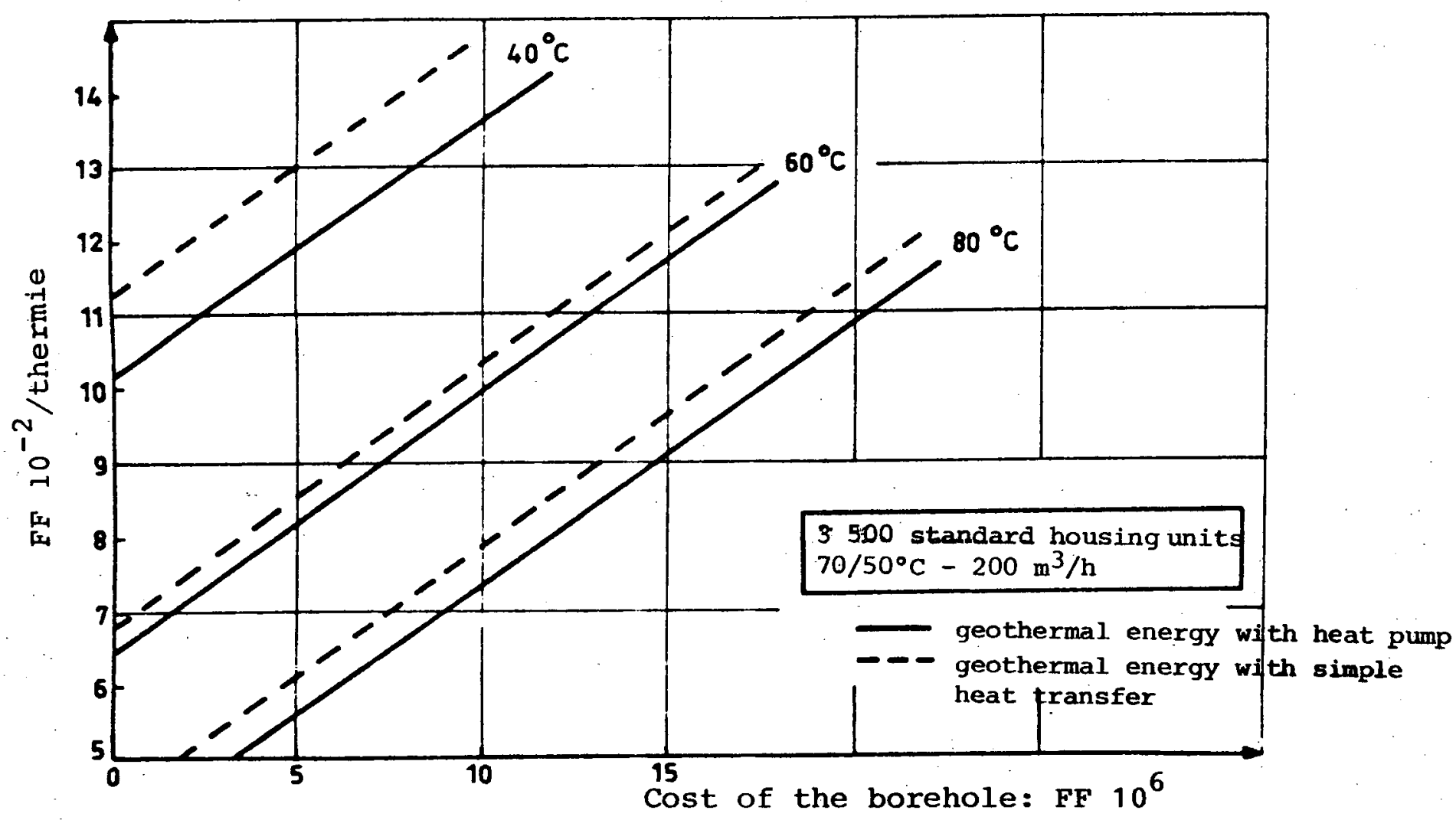

FIGURE III.32 : INFLUENCE OF THE COST OF THE BOREHOLE ON THE DISCOUNTED COST PER USEFUL THERMIE. 


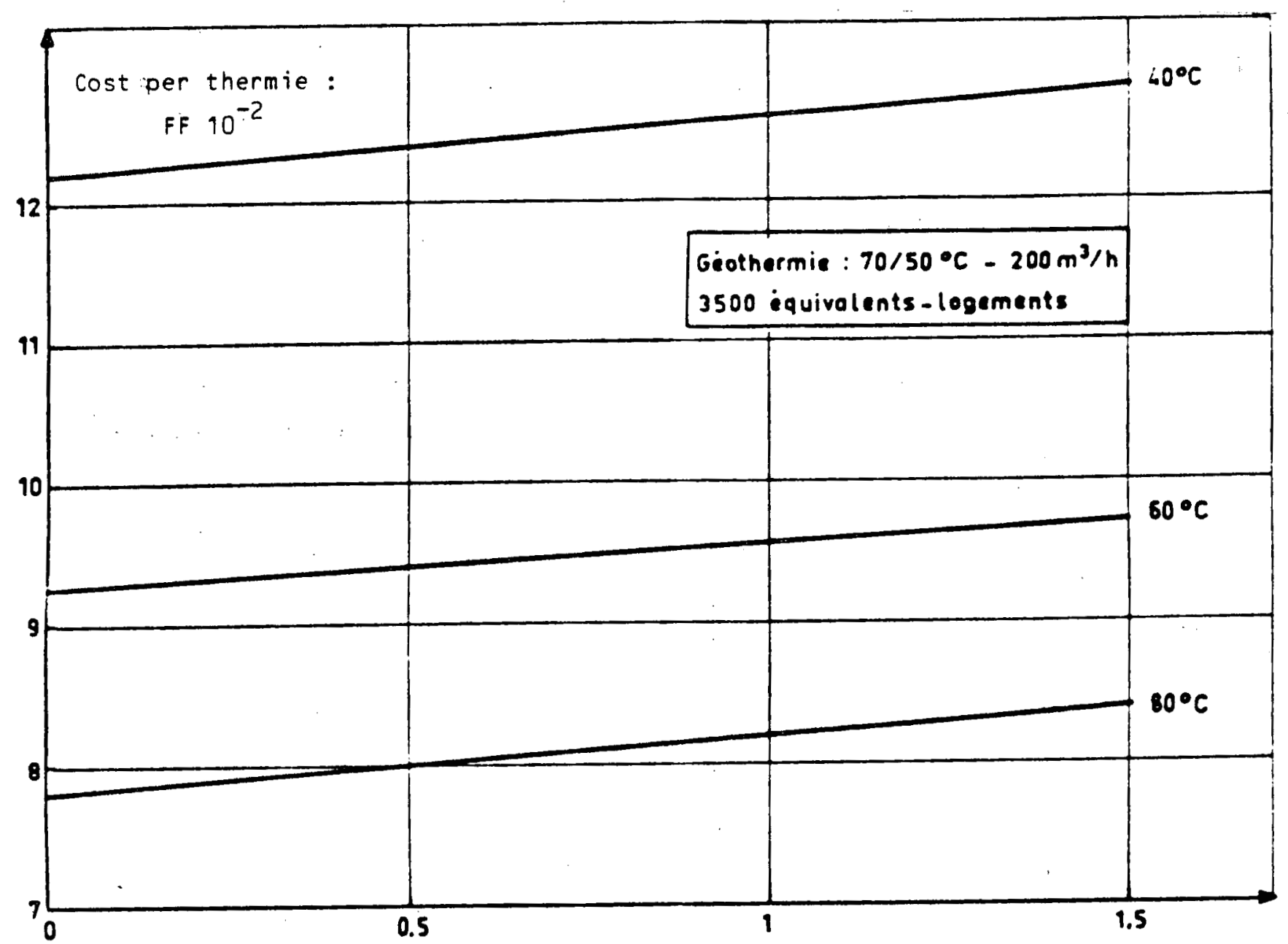

Cost of the heat pump : FF $10^{6}$

FIGURE III. 33 : INFLUENCE OF THE COST OF THE HEAT PUMP ON THE COST PER THERMIE

\subsubsection{Influence of energy costs}

Although investment accounts for a very large proportion of the cost of a geothermal heating project (see Figure III.31), the costs of electricity and additional energy supplies also substantially affect the discounted price per thermie.

In the example given in Figure IIT.34, namely 3500 housing units fitted with $70 / 50^{\circ} \mathrm{C}$ radiators and heated with $200 \mathrm{~m}^{3} / \mathrm{h}$ of geothermal water at a temperature of $60^{\circ} \mathrm{C}$, the cost per 
useful thermie with a heat pump is less than for geothermal heating with simple heat transfer, as long as the average cost of a $\mathrm{kWh}$ of electricity is less than 23 centimes. In both cases, it is still lower than the cost of conventional heating (per thermie) even if the cost of a kWh of electricity reaches 40 centimes, since the cost of the extra fossil-fuel energy is fixed at 10 centimes per thermie.

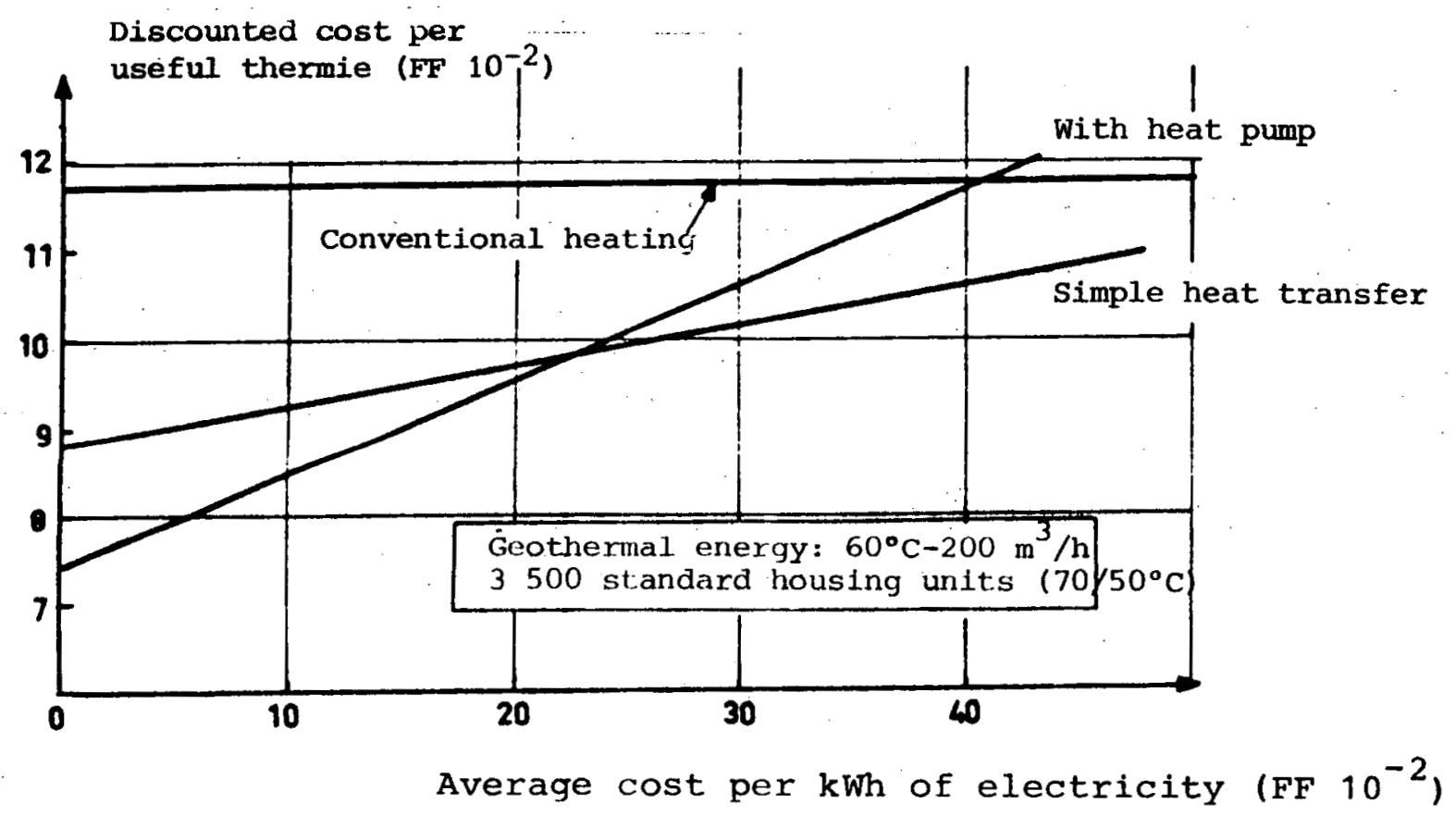

FIGURE III.34 : INFLUENCE OF THE COST OF ELECTRICITY ON THE DISCOUNTED COST PER THERMIE.

The cost of fossil-fuel energy to supplement geothermal energy is more critical when geothermal energy is used with simple heat transfer (see Figure III.35). 


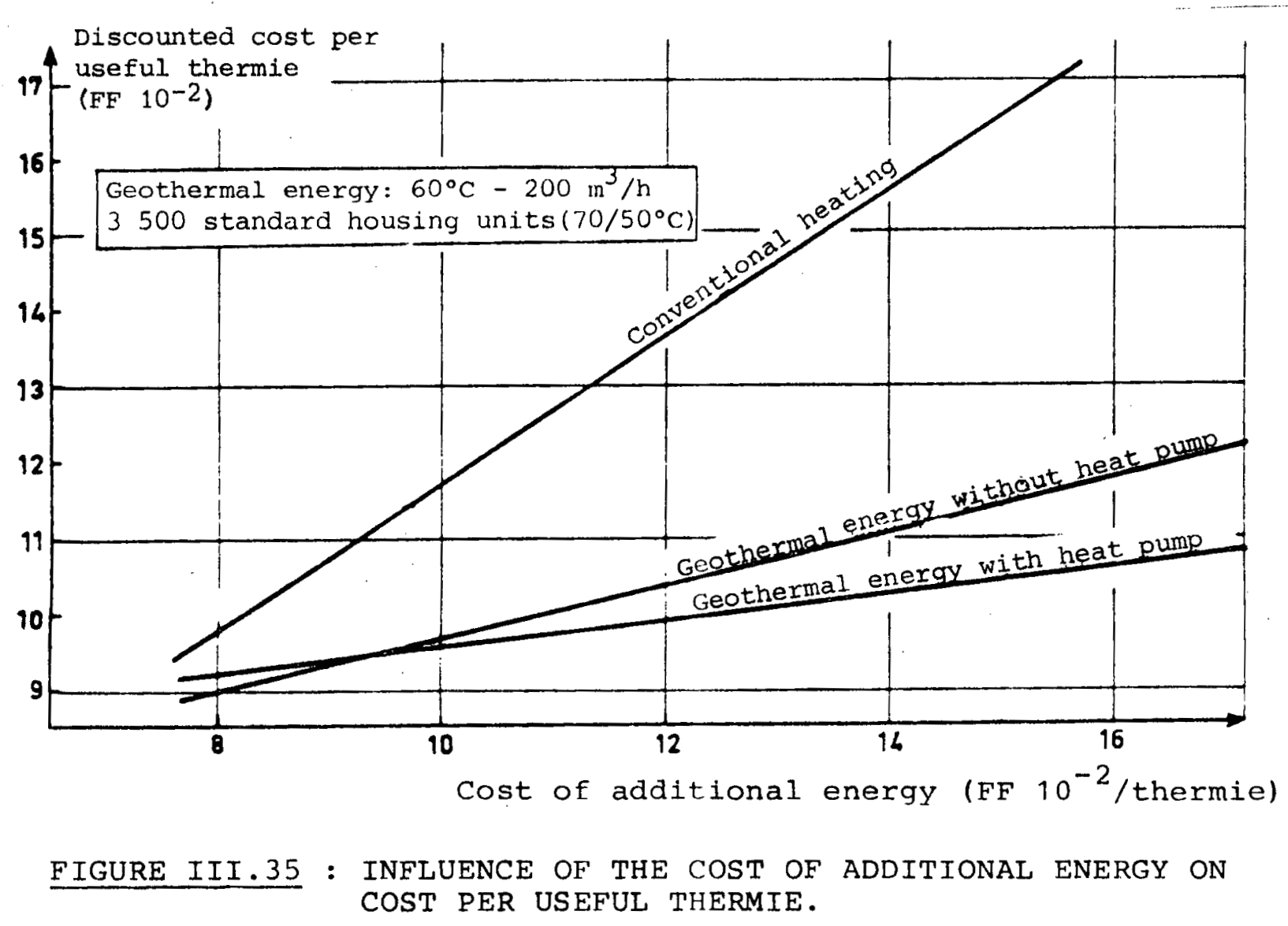

\subsubsection{Influence of the discount rate and period}

Arbitrary assumptions were made for these two economic variables: 98 for the discount rate and 20 years for the discounting period.

If the discounting period were less than this, few geothermal heating projects would be more economic than conventional heating, which requires much less investment. The curve in Figure III.36 shows how the cost per useful thermie varies according to the discounting period. 


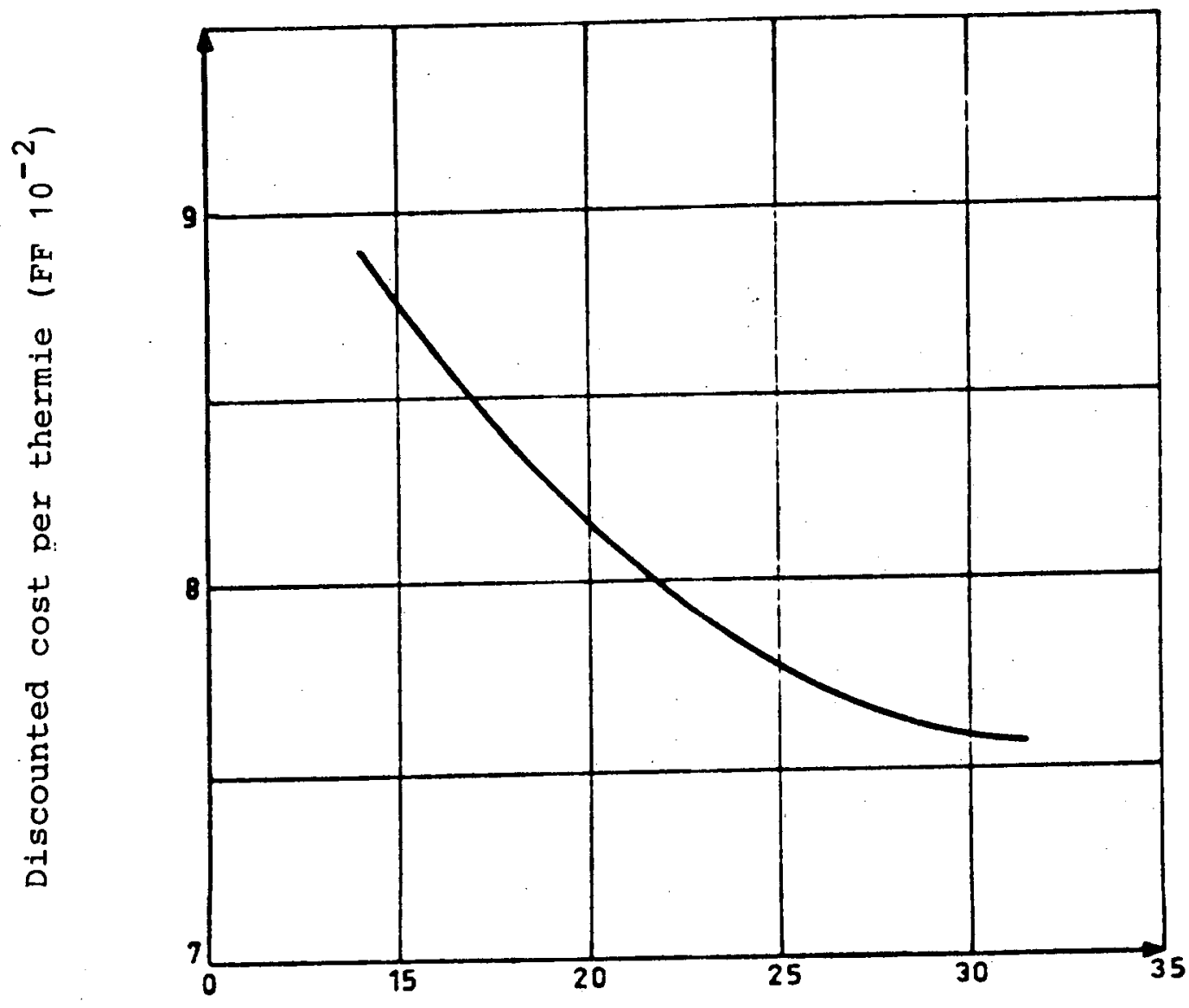

Discounting period in years

FIGURE III.36 : CHANGES IN THE COST PER THERMIE DISCOUNTED AT 98 ACCORDING TO THE DISCOUNTING PERIOD. 


\section{IV - SET OF NOMOGRAMS}

THIS PART OF THE REPORT CONTAINS A SET OF NOMOGRAMS PLOTTED FROM DATA OBTAINED FROM OUR COMPUTER PROGRAM THEY PROVIDE A RAPID INDICATION OF THE COST-EFFECTIVENESS OF A PARTICULAR GEOTHERMAL HEATING PROJECT,

THE REQUISITE DATA ARE AS FOLLOWS :

- GEOTHERMAL CHARACTERISTICS : TEMPERATURE (THE FLOW RATE, WITH PUMPING, IS RECKONED TO BE EQUIVALENT TO $200 \mathrm{~m}^{3} / \mathrm{HR}$ );

- UTILIZATION CHARACTERISTICS: NUMBER OF HOUSING UNITS OR ANNUAL GEOTHERMAL ENERGY CONSUMPTION FOR HEATING AND TEMPERATURE OF THE HEATING ELEMENTS,

THE NOMOGRAMS PROVIDE INFORMATION ON :

- THE PROPORTION OF SUPPLEMENTARY FOSSIL ENERGY:

- THE DISCOUNTED COST PER USEFUL THERMIE;

- THE SAVING IN PRIMARY. ENERGY EXPRESSED AS TONNES OIL EQU IVALENT,

FOR A GEOTHERMAL HEATING PROJECT, WHITH HEAT PUMPS OR NO, THE FIGURES ARE TO BE INTERPRETED AS FOLLOWS :

(I) FIgURES IV, I TO IV, 6 ARE VALID IF THE HEATING ELEMENTS ARE $90 / 70^{\circ} \mathrm{C}$ RADIATORS:

(II) FIGURES IV,7 TO IV, 12 ARE VALID FOR DWELLINGS FITTED WITH $55 / 40^{\circ} \mathrm{C}$ UNDERFLOOR HEATING SYSTEM:

(II I) FIGURES IV.13 TO IV, 18 ARE VALID FOR DWELLINGS HEATED BY $70 / 50^{\circ} \mathrm{C}$ RADIATORS . 
4.1. NOMOGRAMS PLOTTED FOR DWELLINGS FITTED WITH $90 / 70^{\circ} \mathrm{C}$ RADIATORS

\subsubsection{Geothermal heating with heat pump}

Determination of the following values as a function of the number of standard housing units and temperature of the geothermal energy :

- proportion of supplementary fossil energy in the annual amount of heat supplied to dwelling (cf. Figure IV.I);

- cost per useful thermie discounted at 98 over 20 years (cf. Figure IV.2);

- savings in primary energy from geothermal heating compared with conventional oil-fired heating systems (cf. Figure IV. 3).

\subsubsection{Geothermal heating with simple heat transfer}

Determination of the following values as a function of the number of standard housing units and the temperature of the geothermal fluid:

- proportion of supplementary fossil energy in the annual amount of heat supplied to dwellings (cf. Figure IV.9);

- cost per useful thermie discounted at 98 over 20 years (cf. Figure IV.5);

- savings in primary energy from geothermal heating compared with conventional oil-fired heating systems (cf. Figure IV.6). 


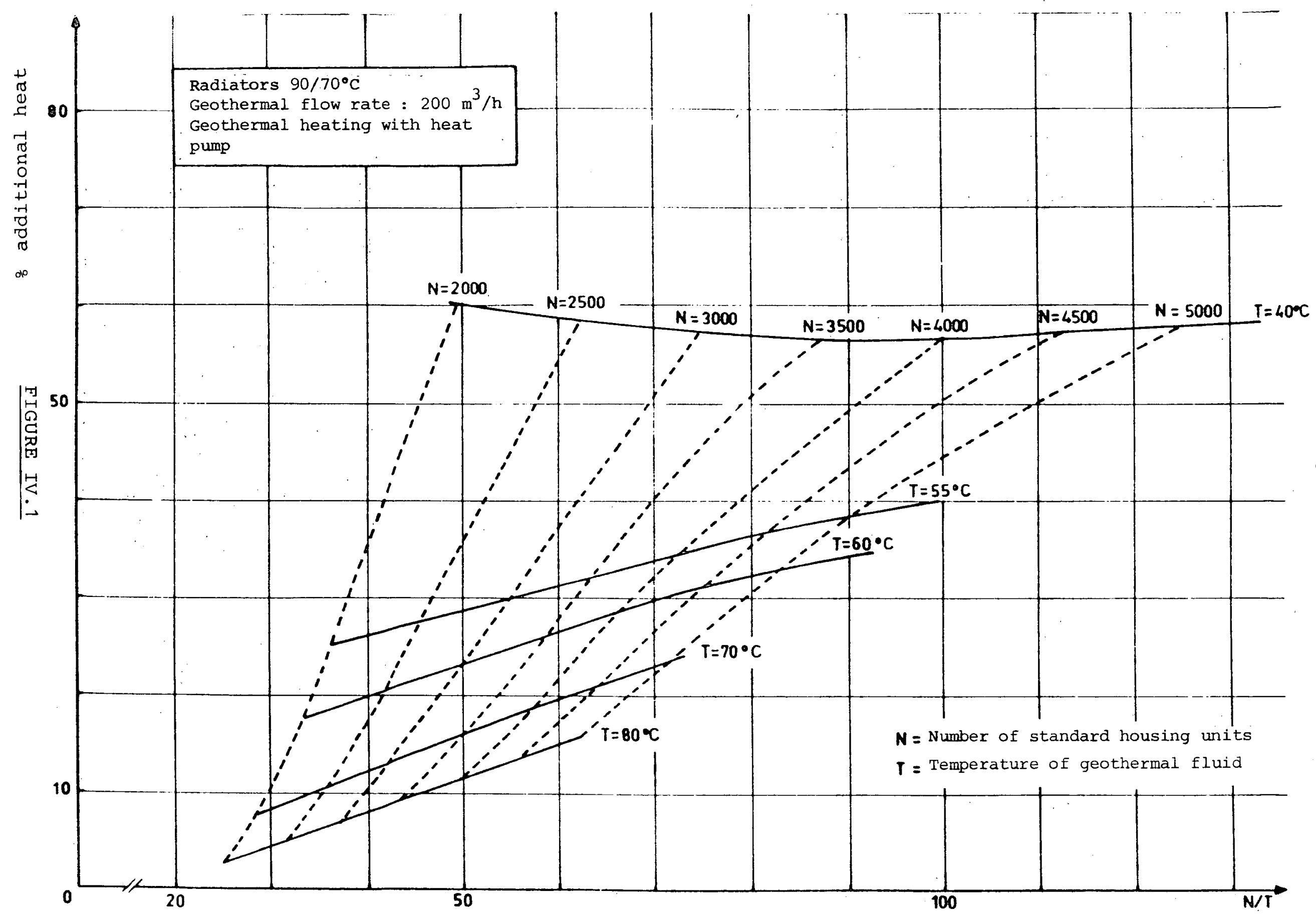




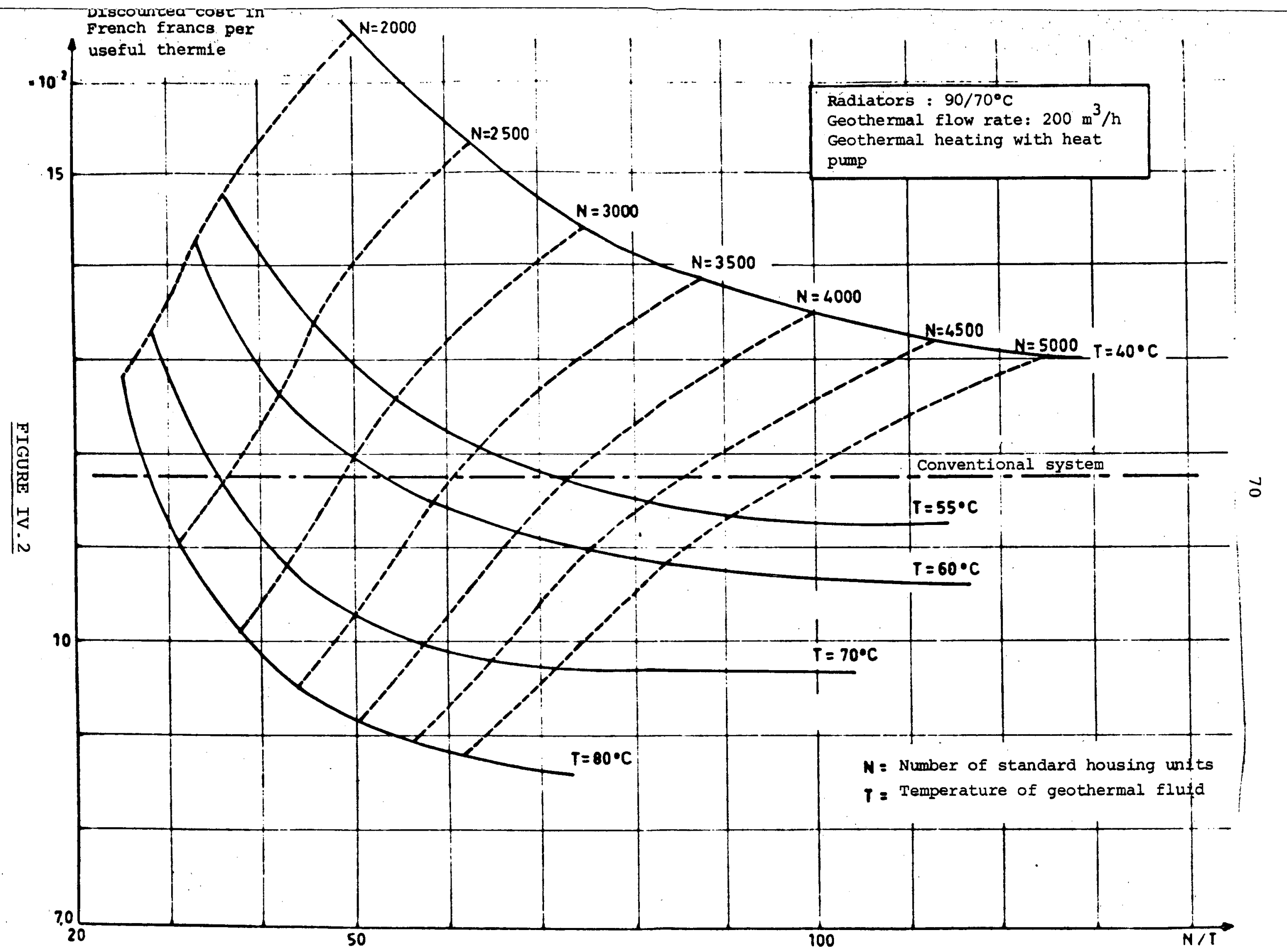




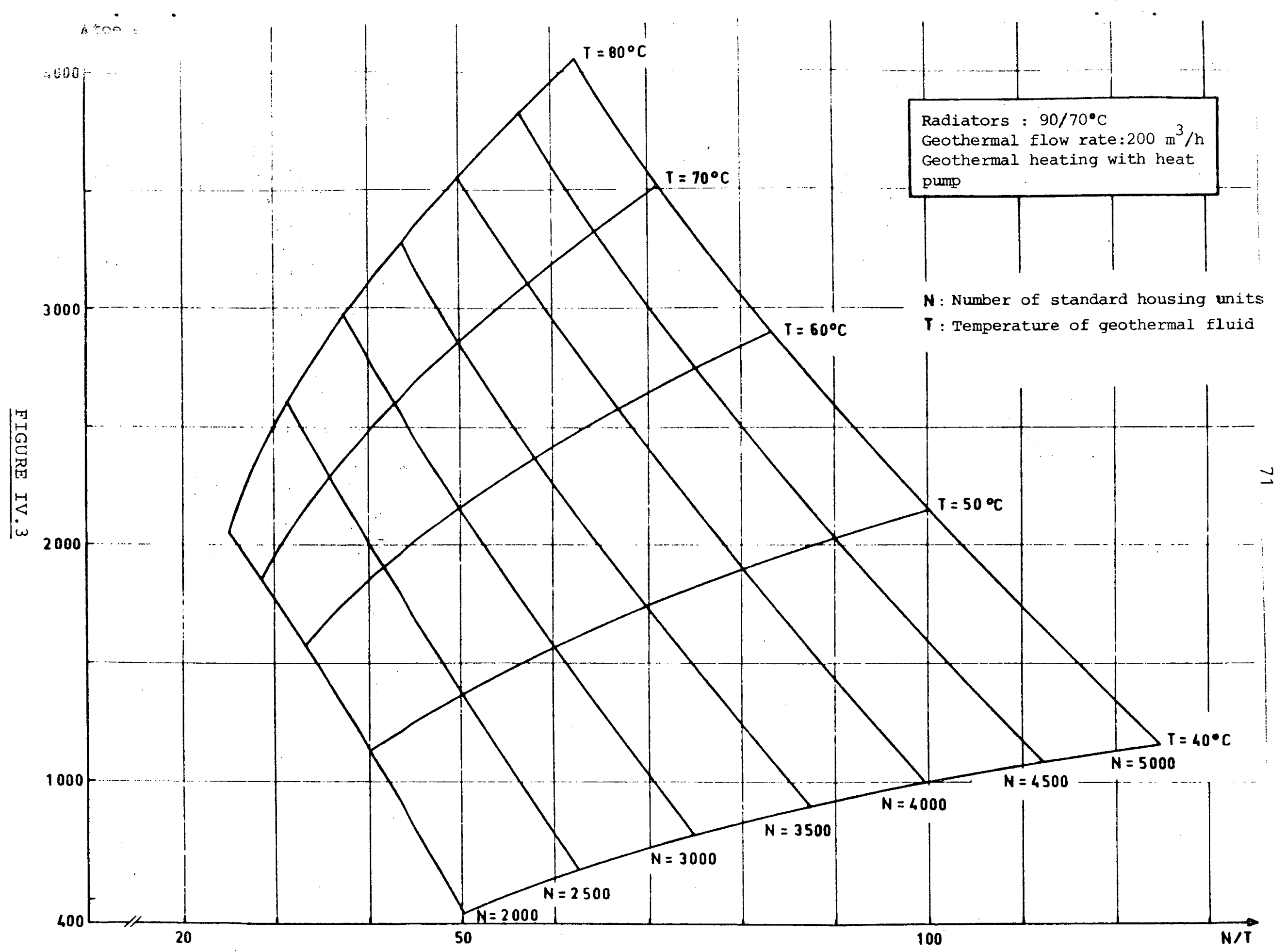




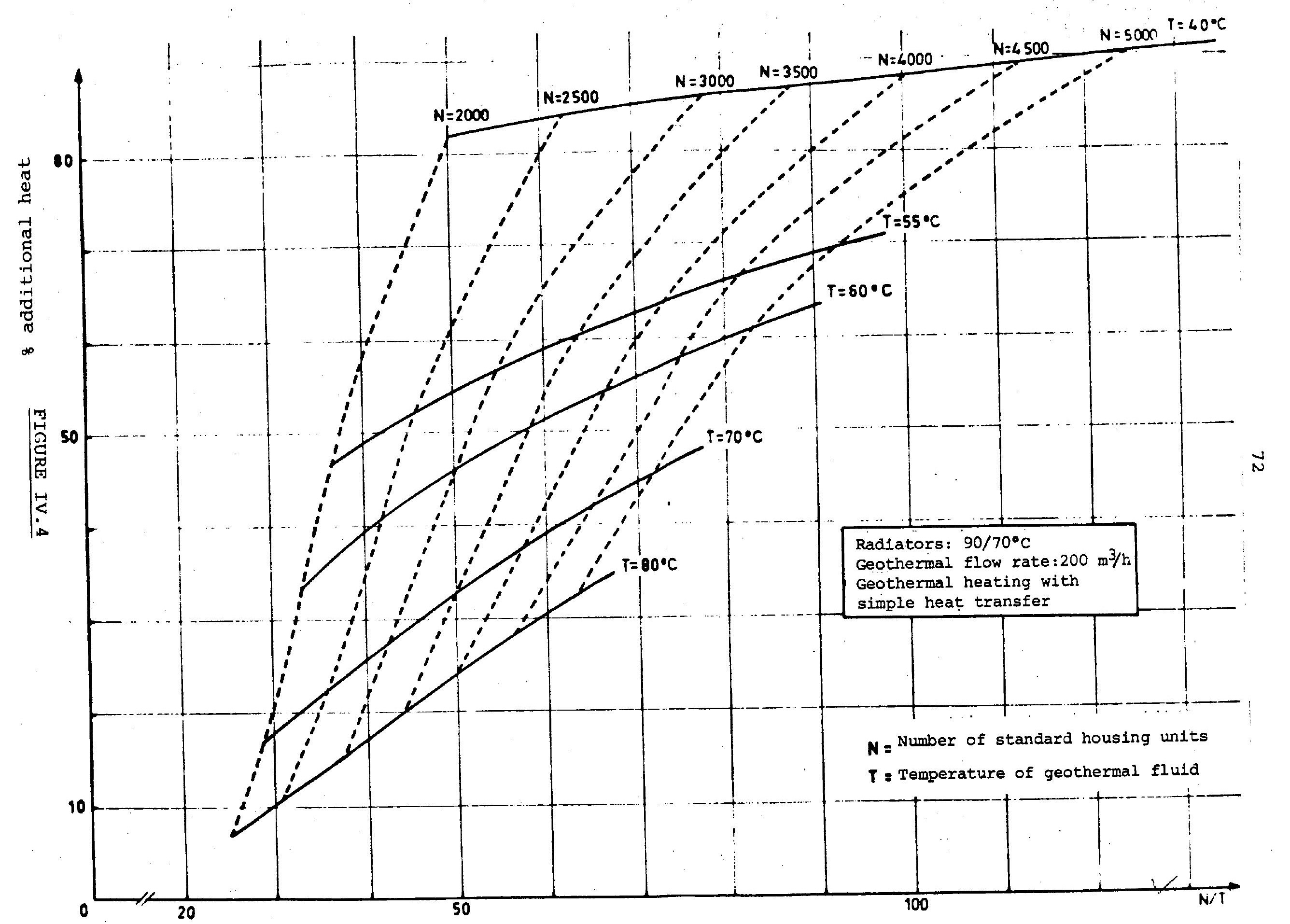




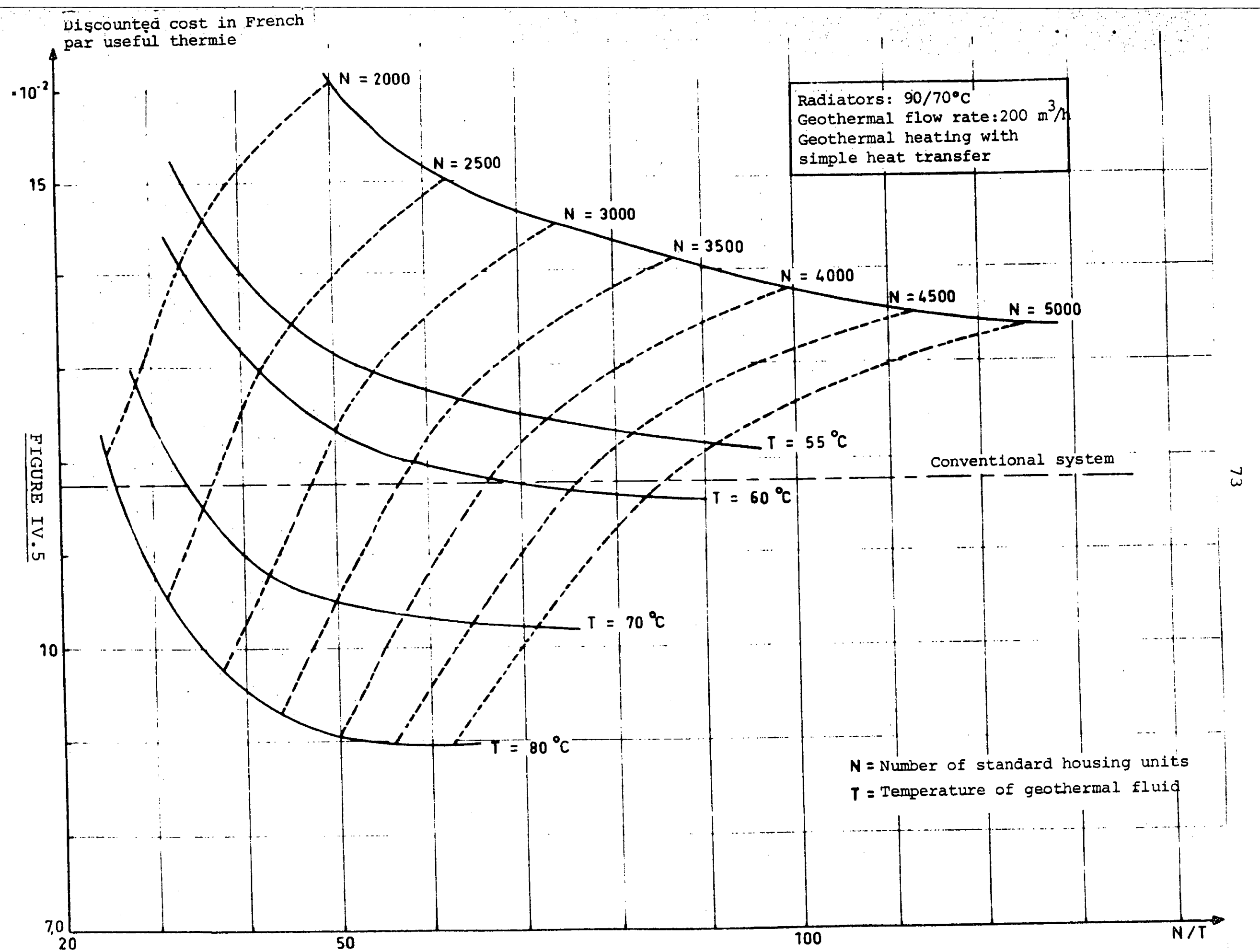




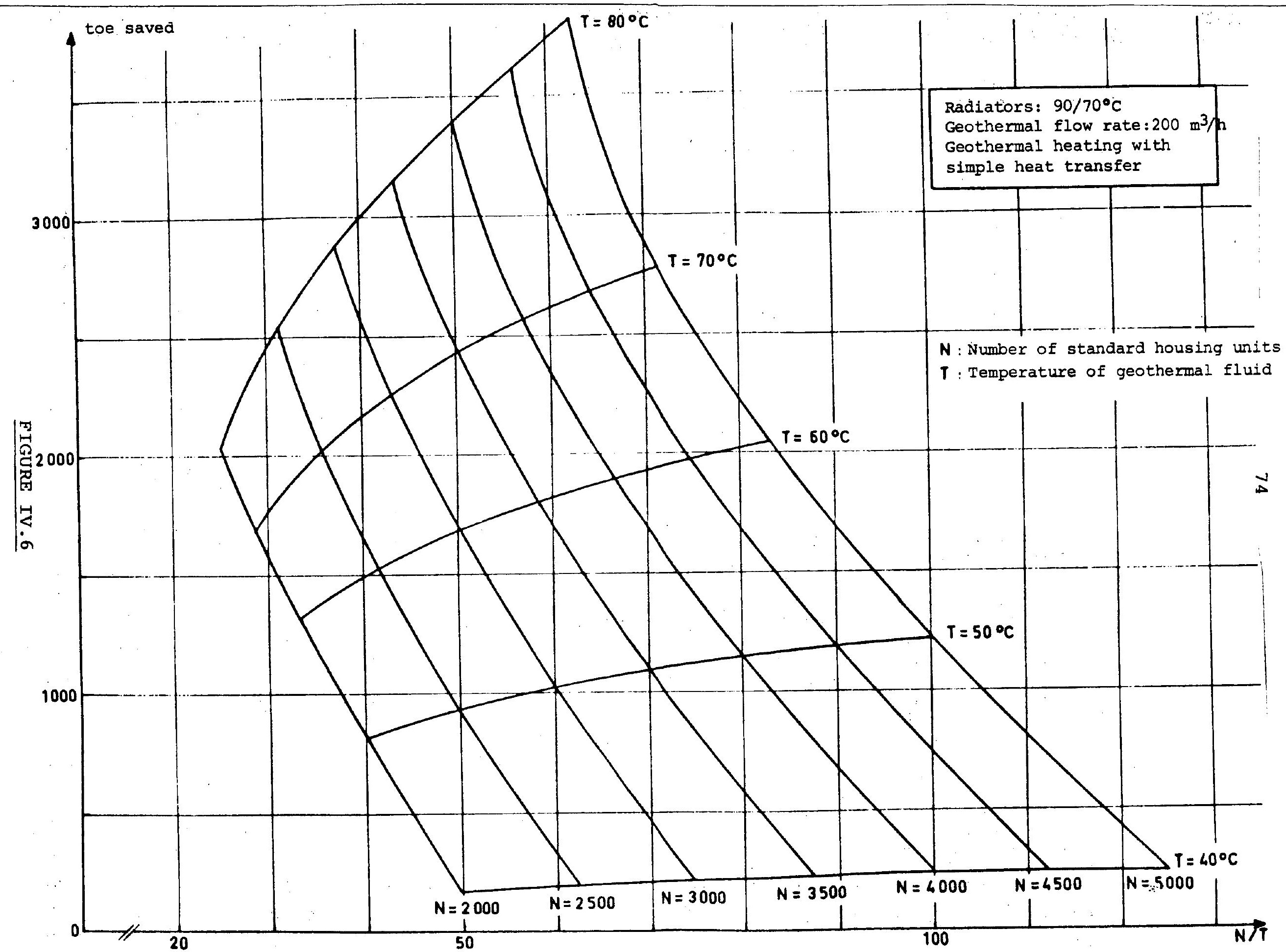


4.2. NOMOGRAMS PLOTTED FOR INELLINGS HEATED BY $55 / 40^{\circ} \mathrm{C}$ UNDERFLOOR HEATING SYSTEMS

\subsubsection{Geothermal heating with heat pump}

Determination of the following values as a function of the number of standard housing units and temperature of the geothermal energy :

- proportion of supplementary fossil energy in the annual amount of heat supplied to dwellings (cF. Figure IV.7);

- cost per useful thermie discounted at 98 over 20 years (cf. Figure IV.8);

- savings in primary energy from geothermal heating compared with conventional oil-firrd heating systems (cf. Figure IV.9).

\subsubsection{Geothermal heating with simple heat transfer}

Determination of the following values as a function of the number of standard housing units and the temperature of the geothermal fluid :

- proportion of supplementary fossil energy in the annual amount of heat supplied to dwellings (cf. Figure IV.10);

- cost per useful thermie discounted at 98 over 20 years (cf. Figure IV.11);

- savings in primary energy from geothermal heating compared with conventional oil-fired heating systems (cf. Figure IV.12). 


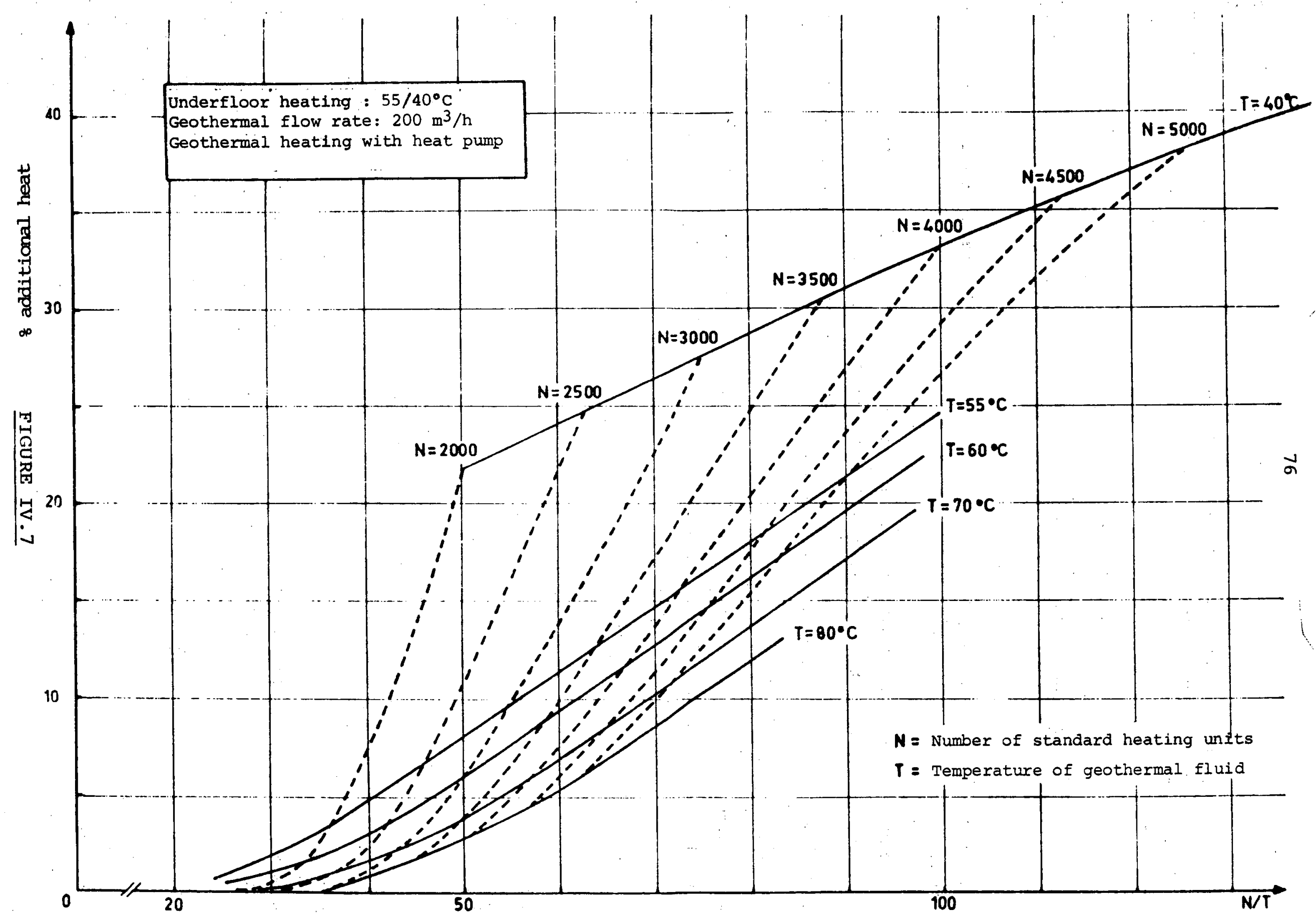




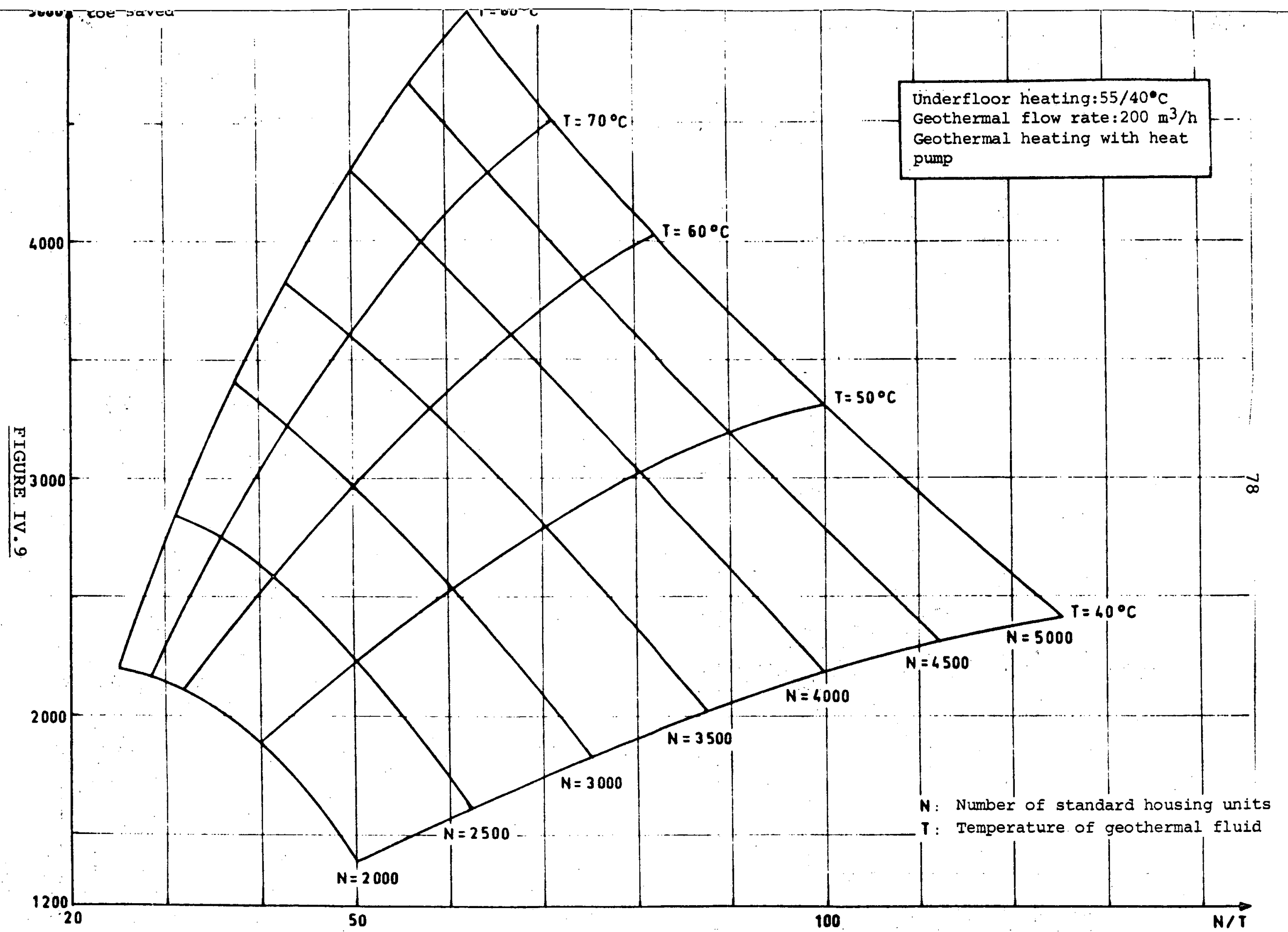




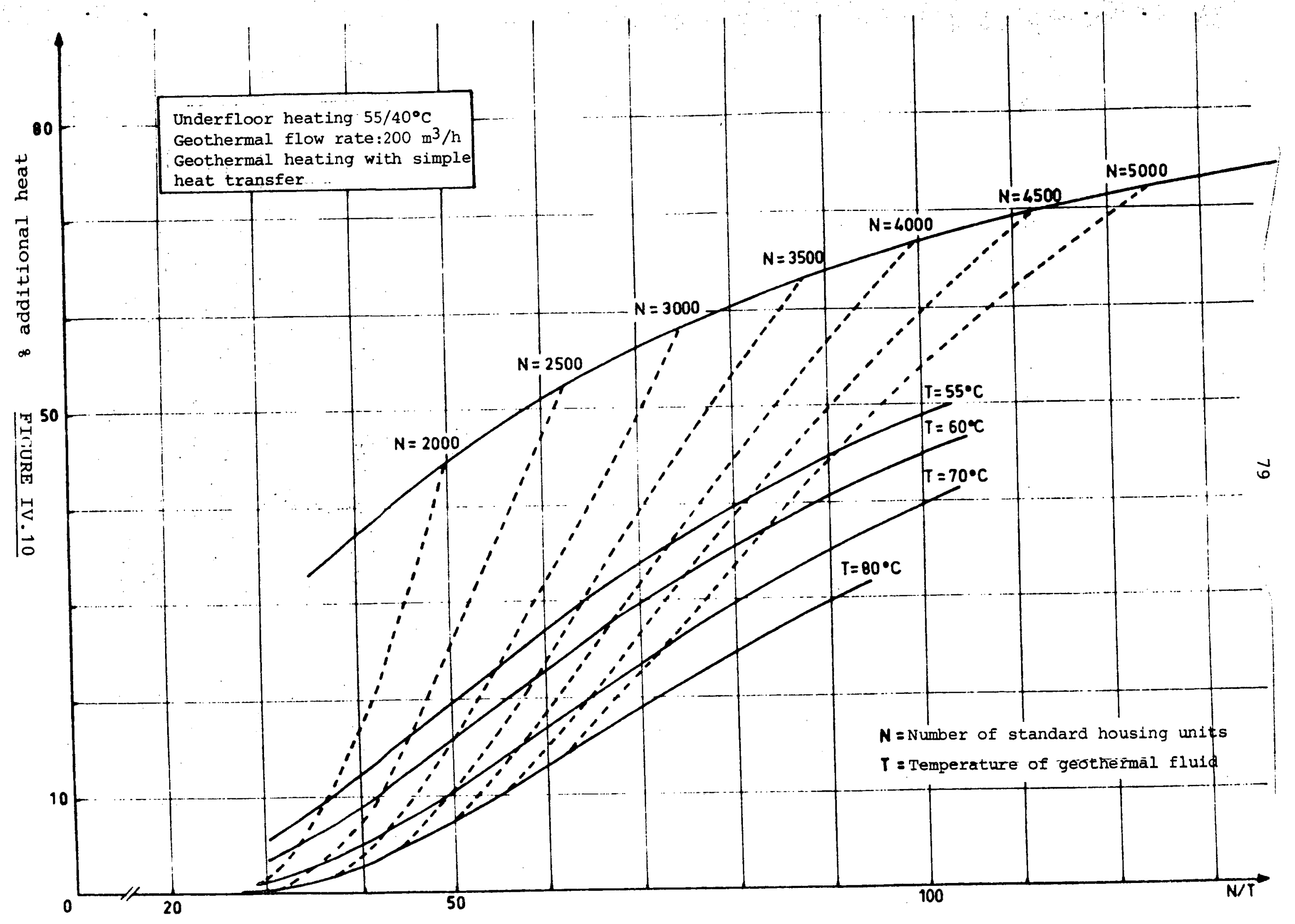




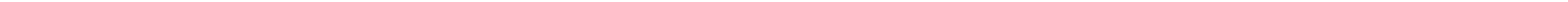




\subsection{NOMOGRAMS PLOTTED FOR DWELLINGS HEATED BY $70 / 50^{\circ} \mathrm{C}$ RADIATORS}

\subsubsection{Geothermal heating with heat pump}

Determination of the following values as a function of the number of standard housing units and temperature of the geothermal energy :

- proportion of supplementary fossil energy in the annual amount of heat supplied to dwellings (cf. Figure IV.13);

- cost per useful thermie discounted at 98 over 20 years (cf. Figure IV. 14);

- savings in primary energy from geothermal heating compared with conventional oil-fired heating systems (cf. Figure IV.15).

\subsubsection{Geothermal heating with simple heat transfer}

Determination of the following values as a function of the number of standard housing units and the temperature of the geothermal fluid :

- proportion of supplementary fossil energy in the annual amount of heat supplied to dwellings (cf. Figure IV.16);

- cost per useful thermie discounted at 98 over 20 years (cf. Figure IV.17);

- savings in primary energy from geothermal heating compared with conventional oil-fired heating systems (cf. Figure IV.18). 


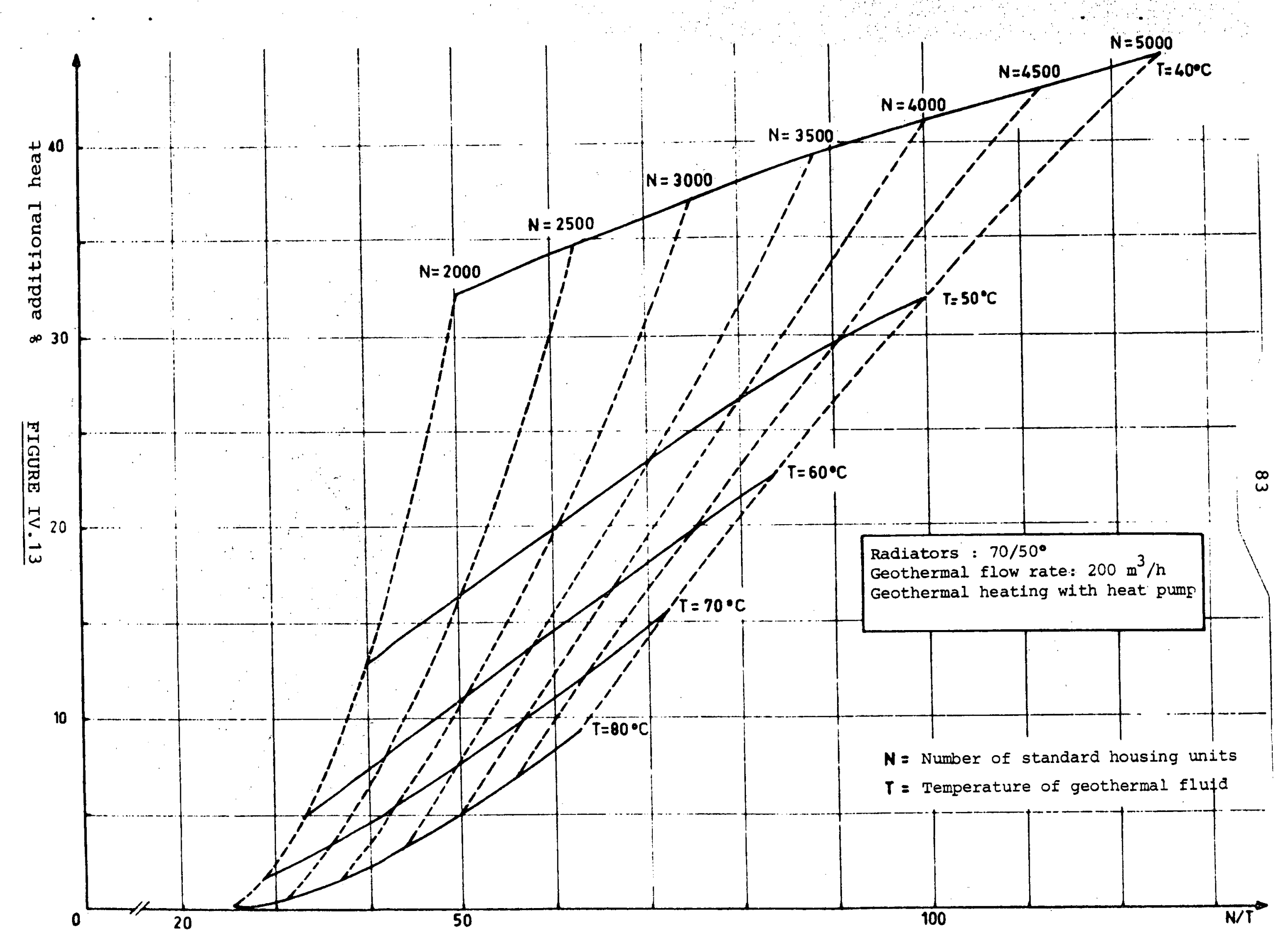




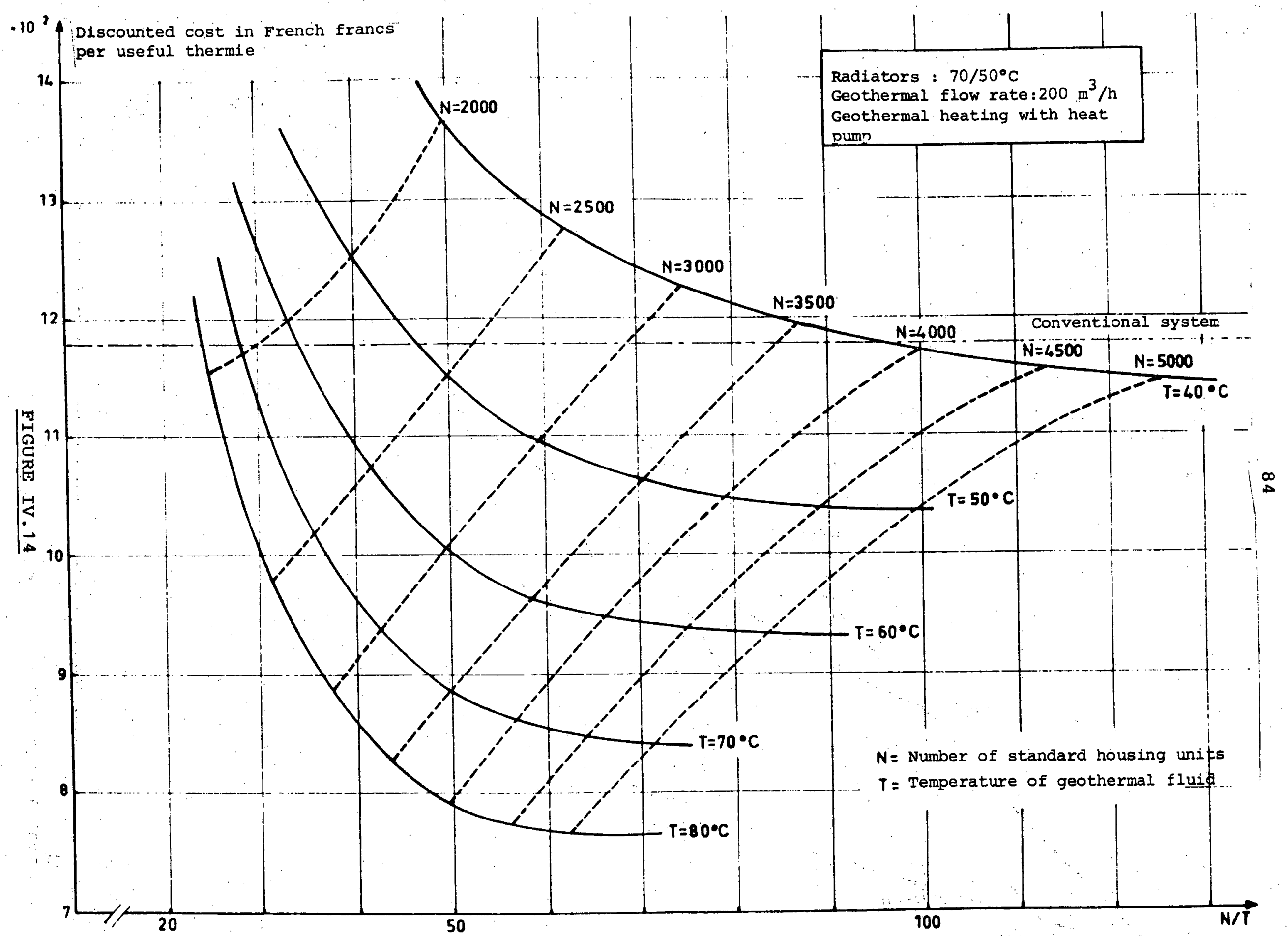




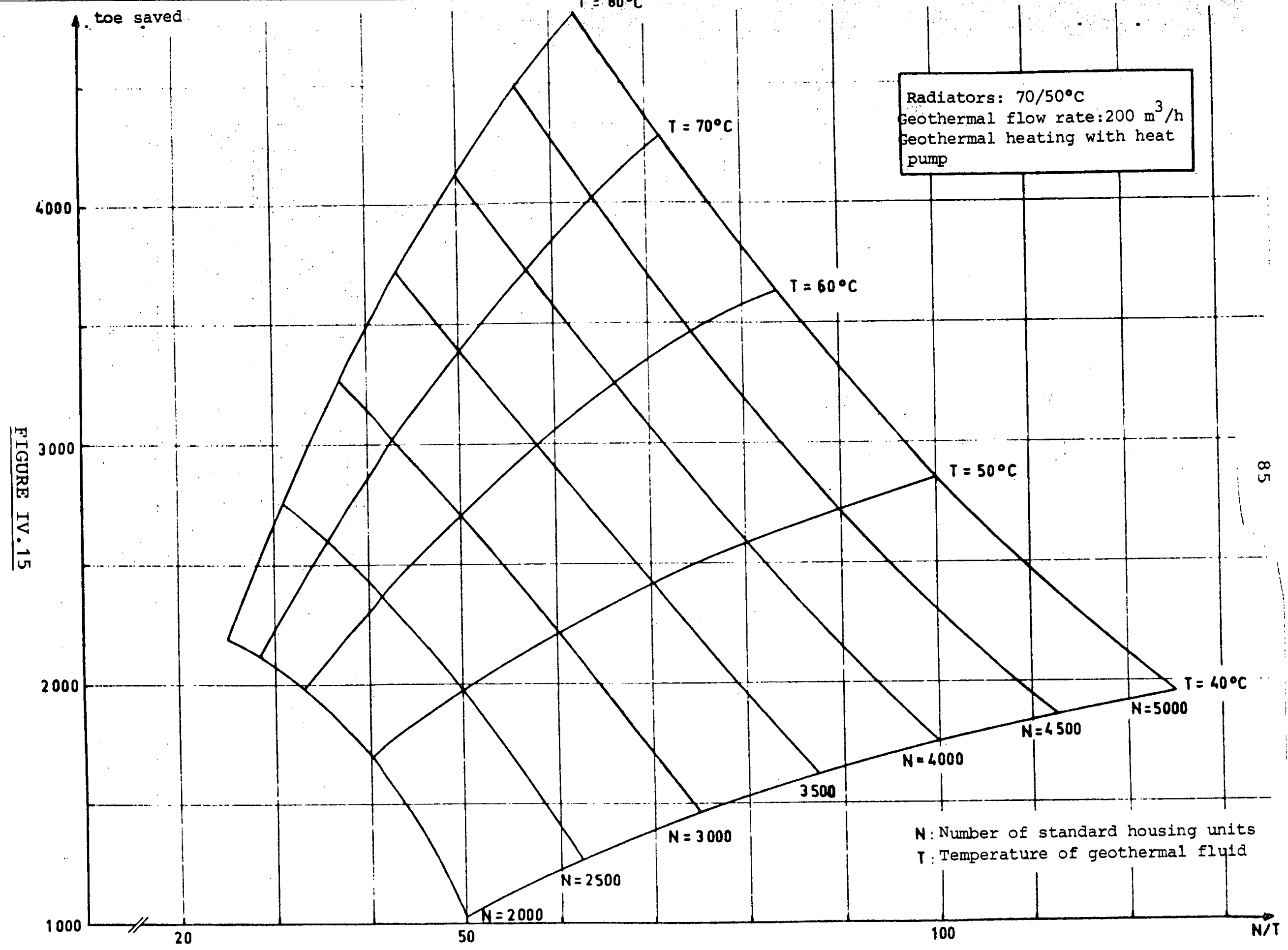




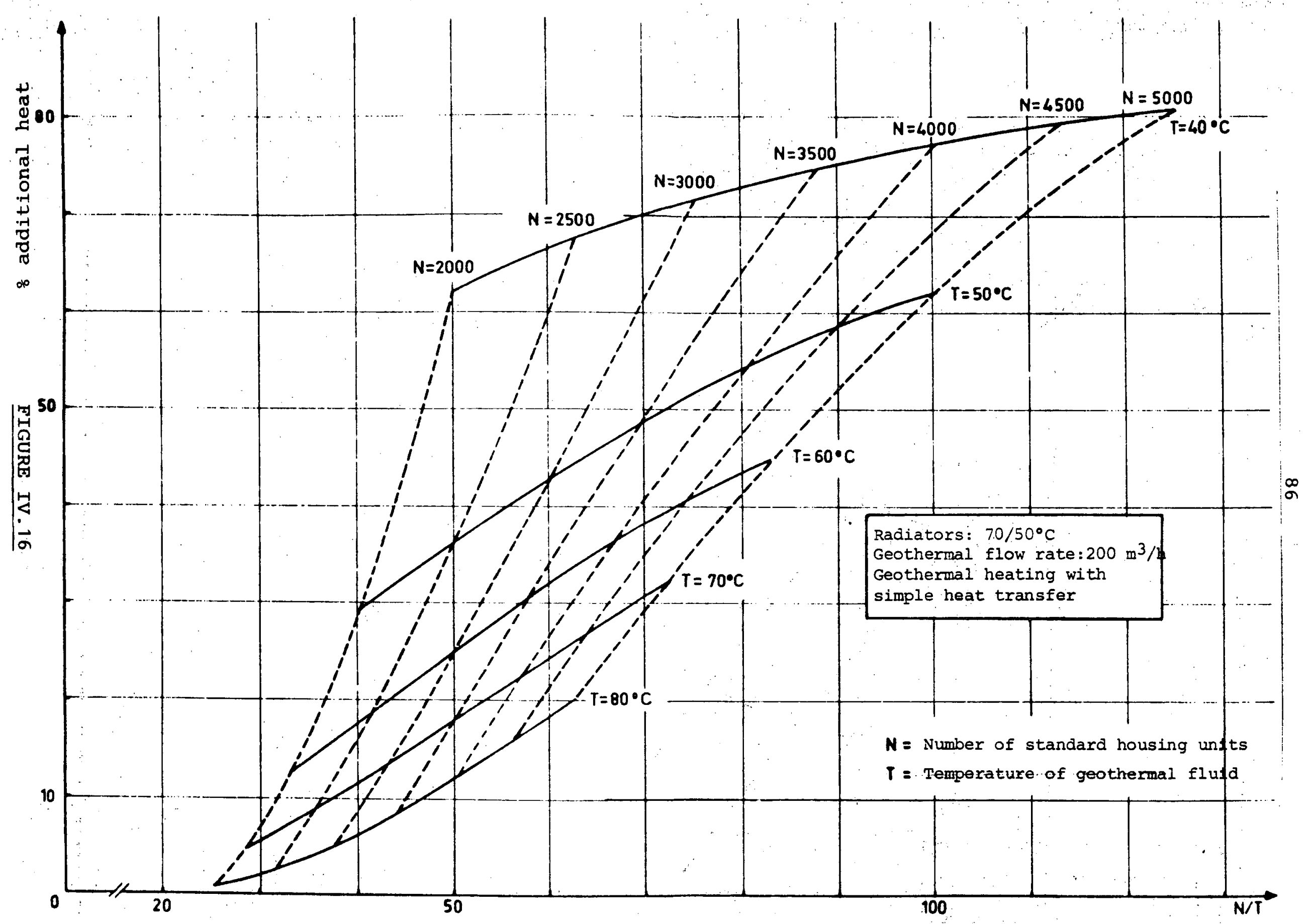




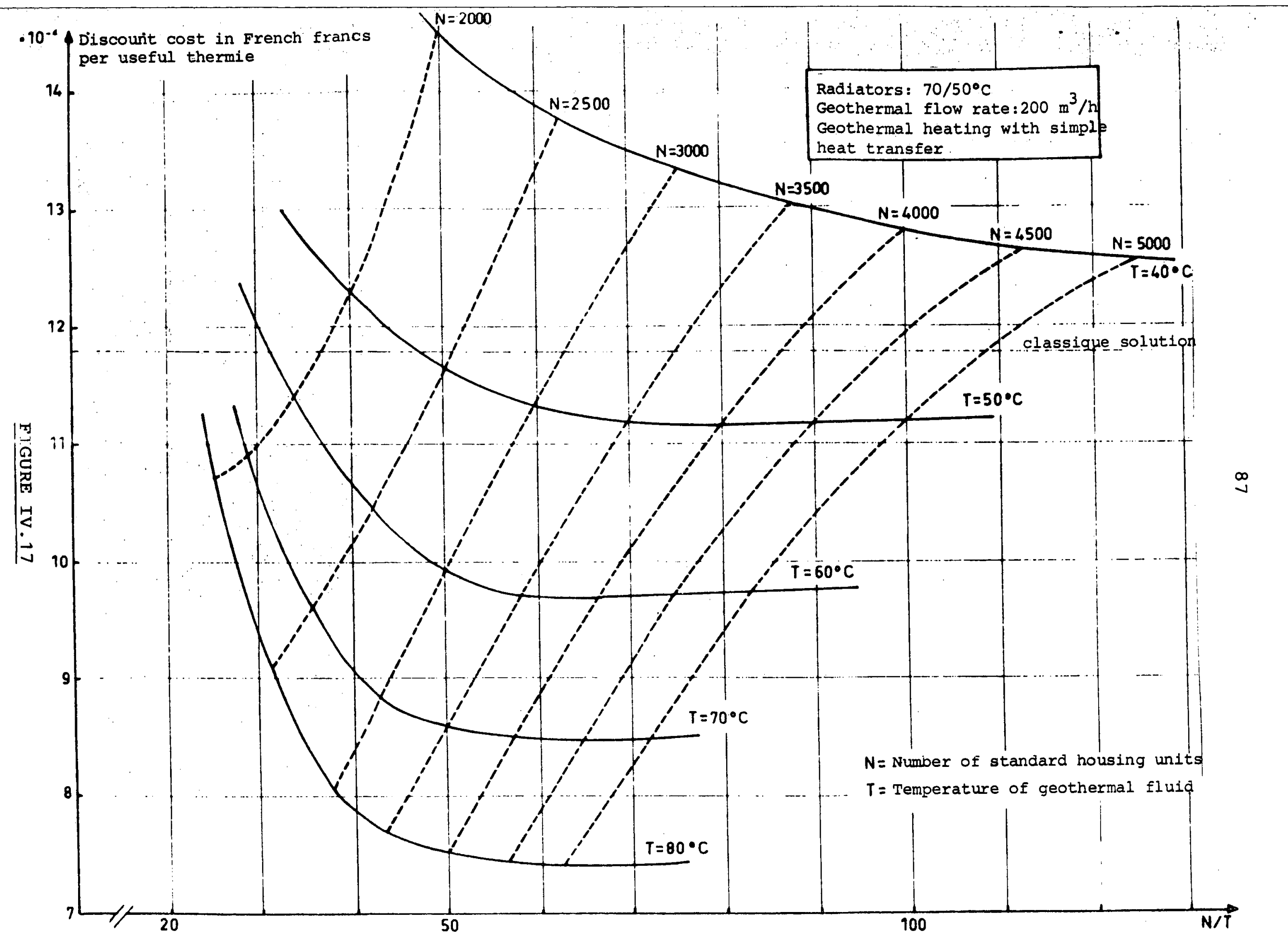




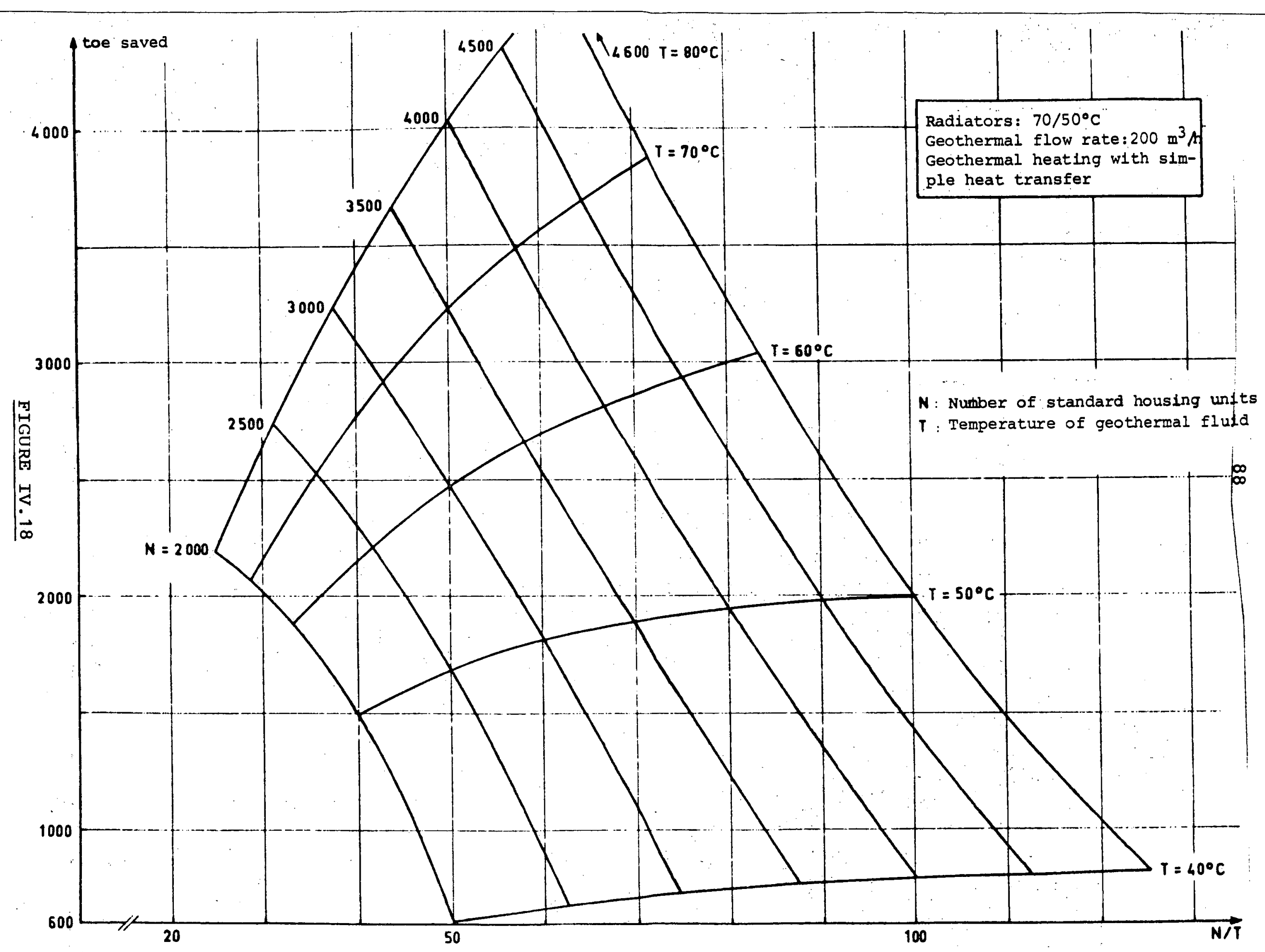


PART FIVE

EXAMPLES OF HOW NOMOGRAMS CAN BE USED

CONCLUSIONS 
V. EXAMPLES OF HOW NOMOGRAMS CAN BE USED AND CONCLUSIONS

Let us take a geothermal heating project for dwellings whose total consumption is known, e.g. $37650 \mathrm{MWh}$ or $32379 \mathrm{kth} / \mathrm{h}$.

The number of standard housing units $(3$ 650) and the characteristics of the geothermal resource such as :

(1) temperature $-58^{\circ} \mathrm{C}$

(2) pumped flow rate $-200 \mathrm{~m}^{3} / \mathrm{h}$. can be determined from curve II.11.

We can now work out the discounted cost per useful thermie, the proportion of supplementary energy and the saving in primary energy for a system using a heat pump or a system with simple heat transfer. Taking the example of a system using a heat pump :

(1) If the radiator temperature range is $90 / 70^{\circ} \mathrm{C}$

$$
\begin{aligned}
\mathrm{N} / \mathrm{T} \# 63 \Rightarrow \text { where } \mathrm{N} & =3650 \\
\mathrm{~T} & =58
\end{aligned}
$$

By interpolating the curves in Figure IV.2, the discounted cost per thermie can be calculated 11.6 centimes and by interpolating the curves in Figure IV. 3 the saving in primary energy can be determined 2300 toe

(2) If the heating elements are $55 / 40^{\circ} \mathrm{C}$ underfloor heating system, the discounted cost per useful thermie is 9 centimes and the saving in primary energy $3 \quad 300$ toe

The results for a geothermal heating system with simple heat transfer can be calculated in the same way.

Since geothermal conditions are often uncertain, it may be worthwhile calculating the range of variation in the cost per 
thermie and in the saving in primary energy as a function of the geothermal temperature :

If $\mathrm{T}=58^{\circ} \mathrm{C} \pm 4^{\circ} \mathrm{C}$

$1 / \underline{T}=62^{\circ} \mathrm{C} \quad \mathrm{N} / \mathrm{T}=59$

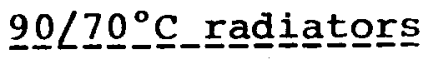

$c=11.15$ centimes

toe $=2500$ toe

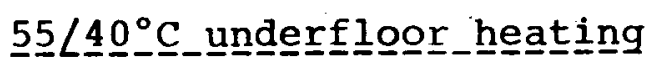

$C=8.6$ centimes

toe $=3450$ toe

$2 / \underline{T}=54^{\circ} \mathrm{C} \quad \mathrm{N} / \mathrm{T}=67.6$

$\underline{9} \underline{0} \angle \underline{70} \underline{0}^{\circ} \underline{\mathrm{C}}$ r $\underline{\text { addi }} \underline{\underline{a}}$ torors

$\mathrm{C}=12.1$ centimes

toe $=2080$ toe

$\underline{5} \underline{5} L \underline{4} \underline{0}^{\circ} \mathrm{C}$ _ung

$C=9.25$ centimes

toe $=3130$ toe

If the price per thermie of fossil energy varies by 10 centimes (basis of calculation), the discounted cost per useful thermie of heating can be calculated from the curves showing the proportion of fossil energy in the energy consumption of the dwellings as a function of the number of dwellings and temperature of the geothermal water.

Thus, the preceding example of a geothermal heating system with a heat pump for 3650 dwellings with $90 / 70^{\circ}$ radiators where $T=58^{\circ} \mathrm{C}$ and $\mathrm{N} / \mathrm{T}=63$, the proportion of additional heat is $29 \%$ 
for an annual consumption of $32.379 \mathrm{kth}, \mathrm{i} . \mathrm{e} .9390 \mathrm{kth}$ of fossil fuel.

The annual fuel costs at 12 centimes/th would be FF 1126800 instead of FF 939000 and the discounted cost per thermie of geothermal heating would be 12.2 centimes instead of 11.6 centimes.

Finally, it can be concluded that the main variables which influence a project for the geothermal heating of existing dwellings are :

(1) the actual consumption of housing units which are in turn determined by their geographical location (climate), characteristics (size, insulation, aspect) and number;

(2) internal heating systems which determine the temperature of the return water to the boiler plant:

(3) the characteristics of the geothermal resource (chiefly temperature, flow rate and constitution of water);

(4) the type of supplementary energy used which determines the cost of the additional energy.

Each individual case can be dealt with by adapting this method to the constraints of the site and the utilization characteristics.

The cost of the hot water distribution network can be taken into account by the method set out in Annex $I$. However, there is no particular need to have aroup of several boreholes for geothermal energy which occurs naturally at the site of the dwellings itself.

The set of nomograms given here provide a rapid indication of :

(1) the proportion of supplementary fossil energy;

(2) the discounted cost per useful thermie, 
(3) the saving in primary energy by using the main variables.

For a proposal project whose conditions differ from the hypotheses used to plot the nomograms a range of determined values can be worked out from the curves showing the influence of the various variables on the results. 
COMMISSION OF THE EUROPEAN COMMUNITIES

ANNEX I

PROGRAM FOR HEAT DISTRIBUTION NETWORKS

Contract No 584.78-7 EGF 


\section{PURPOSE}

The aim of the MERCURE computer program (model investigating the use and recovery of heat in heating networks) is to determine the dimensions and to evaluate the cost of a heat distribution network for which a nomogram has been plotted and main data (heat demand at each point, selected temperature levels, etc.) are known.

The main program outputs are :

(I) of a technical nature:

(i) diameter of pipes;

(ii) head losses and pump ratings;

(iii) heat losses.

(II) of an economic nature :

(i) cost of larging pipes, and installing pumping stations and connections;

(ii) annual maintenance and electricity costs for pumping.

Pipe sizes - and hence the total pressure head of the pumps can be determined to minimize totạl discounted costs (investment plus operating costs). Account can be taken of a phased programme of network construction and customer connection.

Before such calculations can be carried out we must of course know the average unit costs or "probable" costs such as :

(1) cost per linear metre of urban network as a function of diameter: 
(2) specific cost (FF/kW) of pumping stations;

(3) cost of a connection as a function of the type of substation (exchange or mixing) and its rating.

\section{UNIT COST OF PIPING AND SUB-STATIONS}

\subsection{Piping}

After studying a number of different costs for urban heating network projects we can estimate the average costs as a function of diameter for :

(1) civil engineering work (excavation, concrete conduits, etc.);

(2) thermal equipment (piping, valves, relief valves, etc);

(3) the total cost per linear metre of network (see Figure 1) which includes the above two items of expenditure and additional costs arising from particular problems encountered (obstacle necessitating detours, extreme depths, wet subsoil, etc.) (see Figure 2).

\subsection{Sub-stations}

The same method can be used to determine the average cost of a sub-station as a function of its rating. Figure 3 shows the average cost of exchange sub-stations (primary and secondary circuits separated by a high $-\left(180^{\circ} \mathrm{C}\right)$ or low - $\left(110^{\circ} \mathrm{C}\right)$ pressure exchanger). The flowchart for this type of sub-station is given in Figure 4. It can be seen that the specific cost of these sub-stations increases sharply as rating decreases (particularly below $500 \mathrm{~kW}$ ). 


\section{EXAMPLE OF THE RESULTS OF THE COMPUTER PROGRAM}

The example given below concerns a distribution network for 90000 standard housing units with gradual connecting-up of the elements of the circuit (Figures 5 and 6 ).

The main characteristics of the network are :

(i) total length: $60 \mathrm{~km}$;

(ii) peak capacity: $440 \mathrm{MW}$;

(iii) fluid: water under high pressure at $180^{\circ} \mathrm{C} / 90^{\circ} \mathrm{C}$;

(iv) average rating of a sub-station: 800 th/h.

The results obtained from optimization of the network are shown in Figure 7 .

It will be seen in particular that:

(i) Optimum flow speeds range from $1 \mathrm{~m} / \mathrm{s}$ (small-diameter pipe) to $2.6 \mathrm{~m} / \mathrm{s}$ (large-diameter pipe);

(ii) heat losses range from 48 in winter to $11 \%$ on average throughout the year;

(iii) the electrical consumption for pumping is low compared with the amount of heat distributed (18).

Pumping costs, however, account for a sizable proportion of the cost of distribution proper (see below).

The total specific investment is FF $430 / \mathrm{kW}$ and can be broken down as follows :

(i) pipe network: 828 ;

(ii) pumping stations: 38 ;

(iii) sub-stations: 158 . 


\section{OPTIMIZATION AND COST OF NETWORKS}

A number of general conclusions can be drawn from a systematic use of the computer program for different configurations of network by varying its size, form and technical characteristics (temperature of fluid, permissible loss of pressure head, method of covering heat demand by varying flow rate and temperature variables).

\section{Optimization of network}

(i) The optimum value for the total loss of head in the circuit - which reduces the total investment on for piping and the pumping costs (cost of pumps and electricity for pumps) is extremely low. Since it is hence unnecessary to determine it exactly, larger diameters. can be accommodate any increases in capacity (see Figure 8).

(ii) The method chosen to regulate the amount of heat supply which can involve varying a) the flowrate, b) the temperature, or c) both at once has a very significant influence on the annual utilization time of the circulating pumps; hence it affects the optimum value referred to above. It is obvious that more energy will be consumed by regulating at a constant flow rate irrespective of the heat load; however, it is not always easy to vary the flow rate (scattered appliances with widely differing off takes and variable-speed pumps) and some other imperatives such as the need to maintain a minimum temperature for some users may also be taken into account.

(iii) Generally speaking, the relative shares of piping and pumping costs ( 808 for pipes and 208 for pumping) remain constant when pipes of optimum diameter have been used i.e. for a total minimum discounted cost. 
The percentage of annual heat losses for a new network (logging in good condition) is about $10 \%$ of the energy distributed.

\section{Network variables}

(i) The main factors which influence the cost of a network are the "thermal density" of connected appliances laggregate rating of connected applicances per $\mathrm{km}^{2}$ ) and the "network density" which reflects the length of the network required for a particular area (see Figure 9).

(ii) The size of the area served (Figure 10) the effective temperature range of the heat-transfer fluid; however the initial and return temperatures are variables with a less marked influence.

(iii) By increasing the number of heat sources (boiler plants, geothermal boreholes, etc.) to supply heat to a given area, the cost of a network can be greatly reduced as the requisite throughput capacity of the piping is reduced (Figure 12). 
A1.6

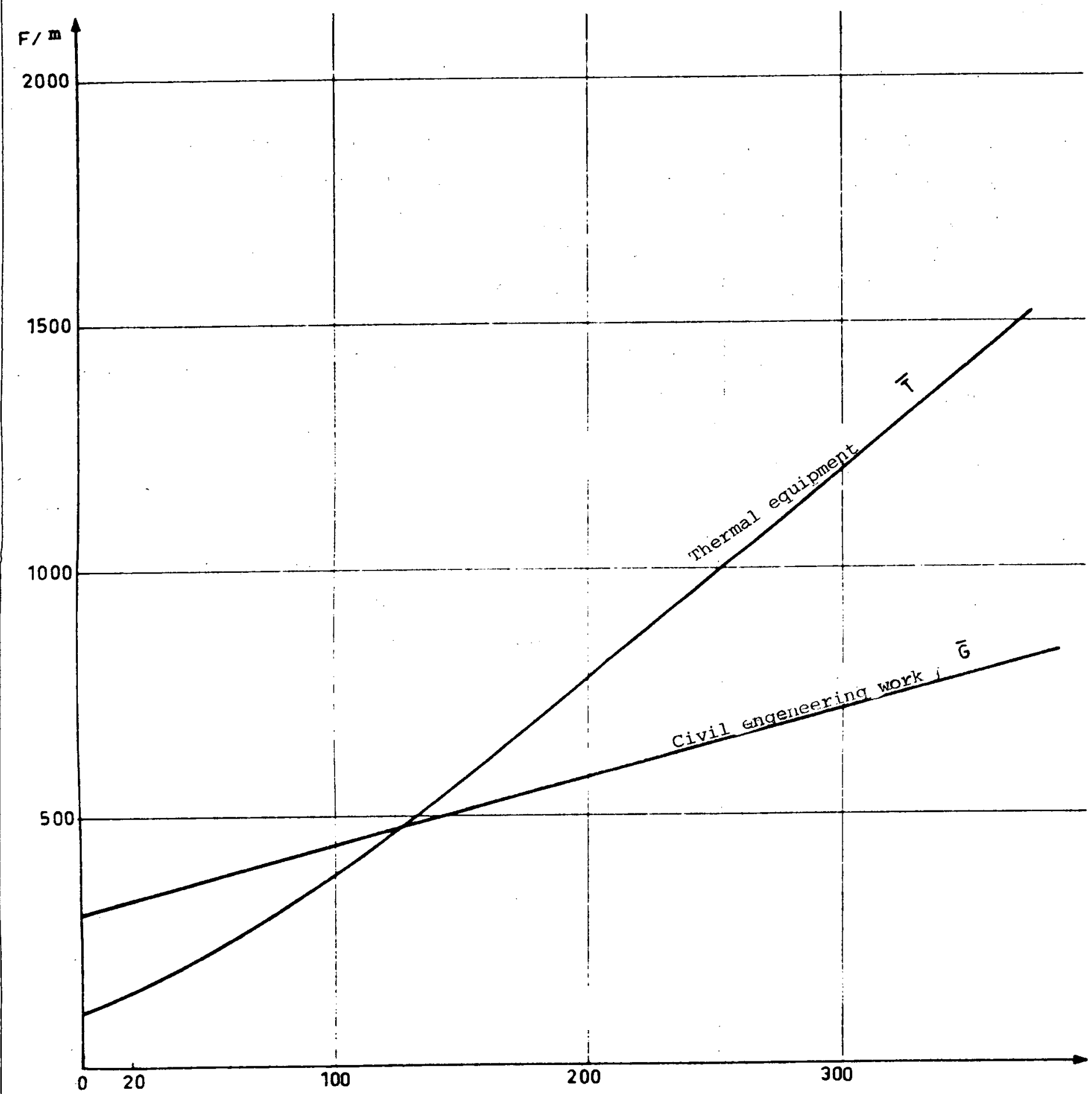

FIGURE 1 : COST PER LINEAR METRE OF_NETWORK (STEEL/CONDUITS), CIVIL ENGINEERING WORK $(\bar{G})$ AND THERMAL EQUIPMENT $(\bar{T})$ EXCLUDING PIPE-LAYING COSTS (DISCOUNTED PRICES AS AT MAY1978) . 


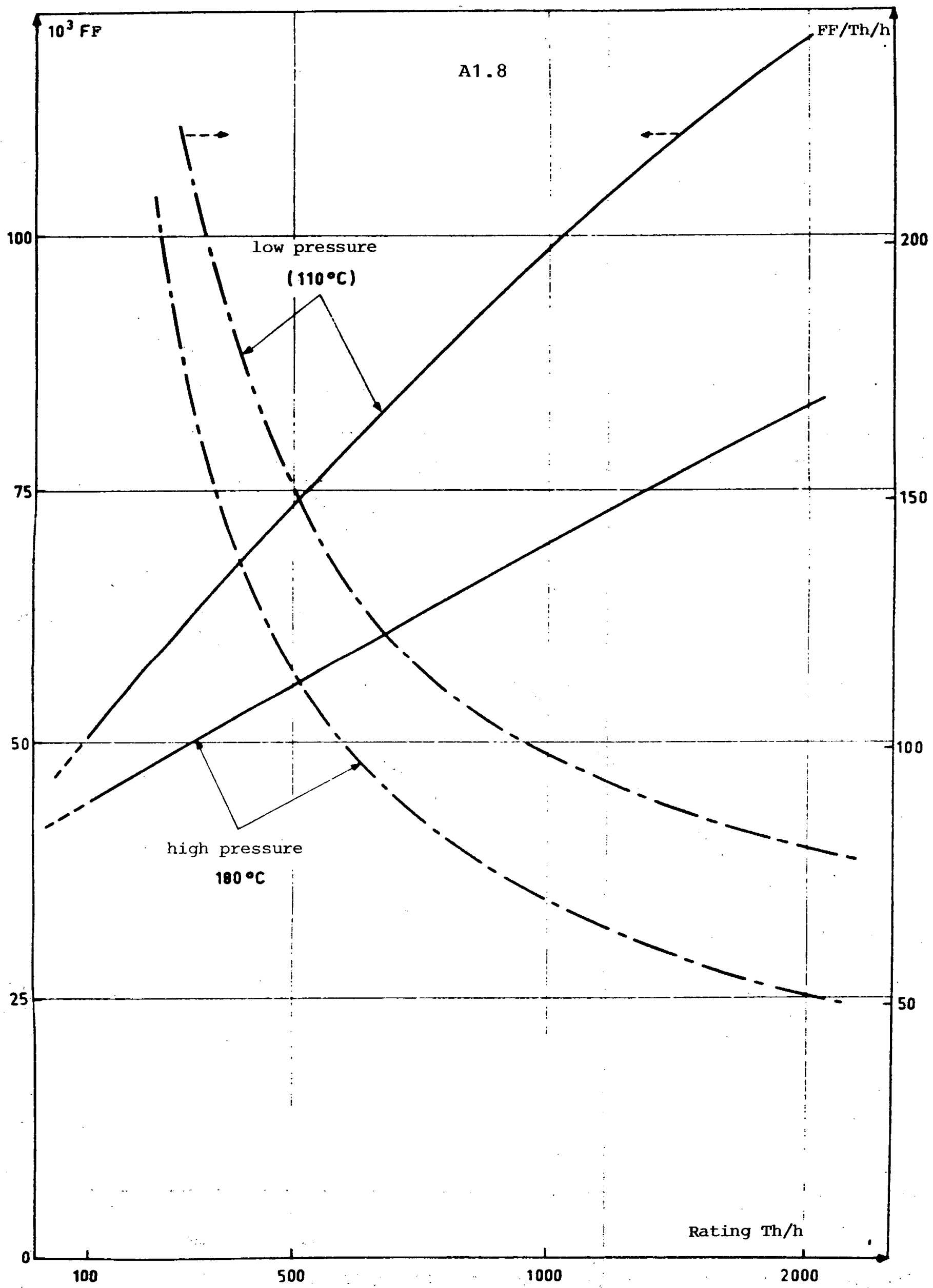

FIGURE 3 : COST OF EXCHANGE SUB-STATIONS (1978 PRICES) 


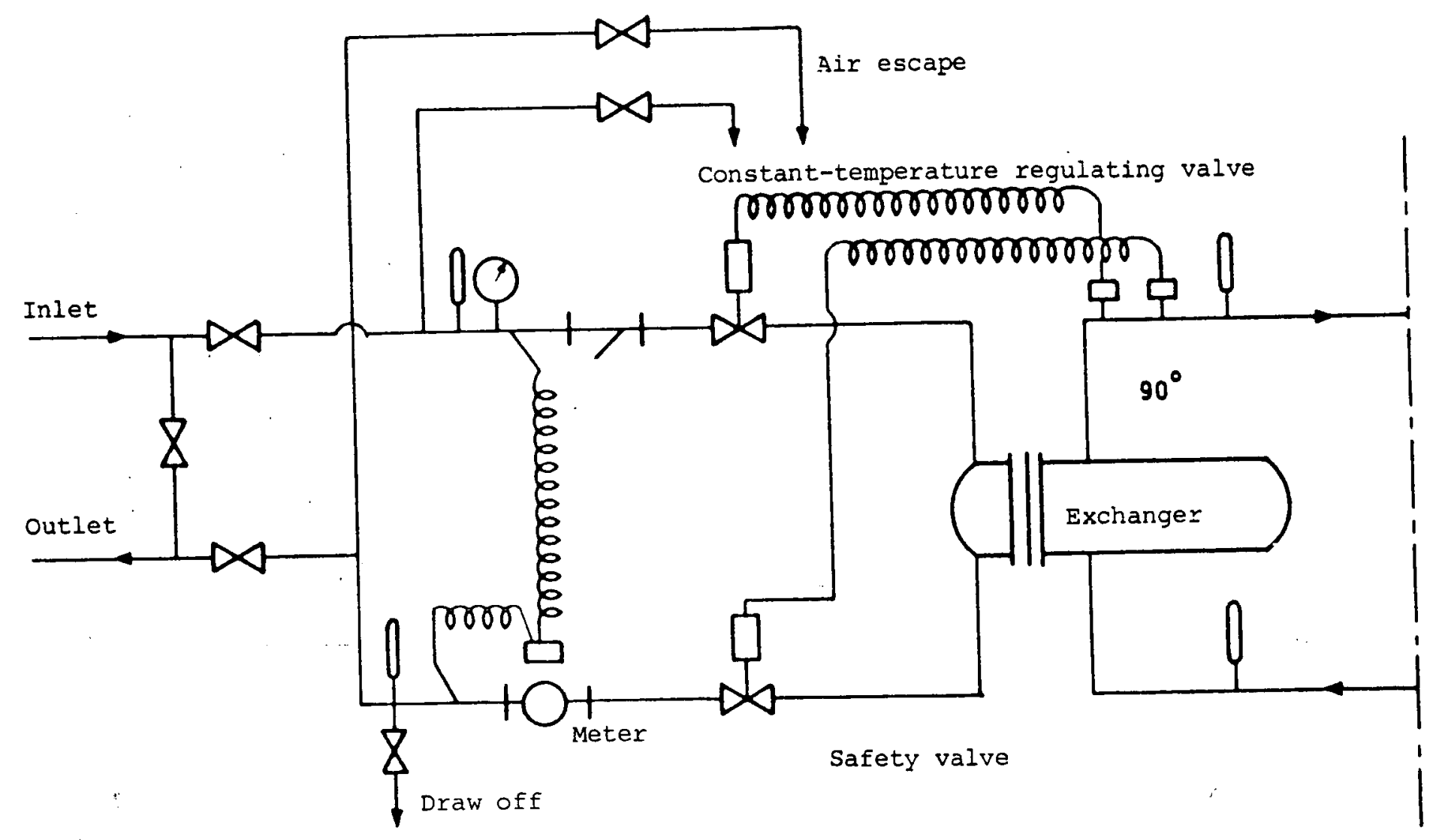

FIGURE 4 : CIRCUIT OF HIGH-PRESSURE AND LOW-PRESSURE EXCHANGE SUB-STATIONS WITH SECONDARY OUTLET AT A CONSTANT TEMPERATURE OF $90^{\circ}$. 


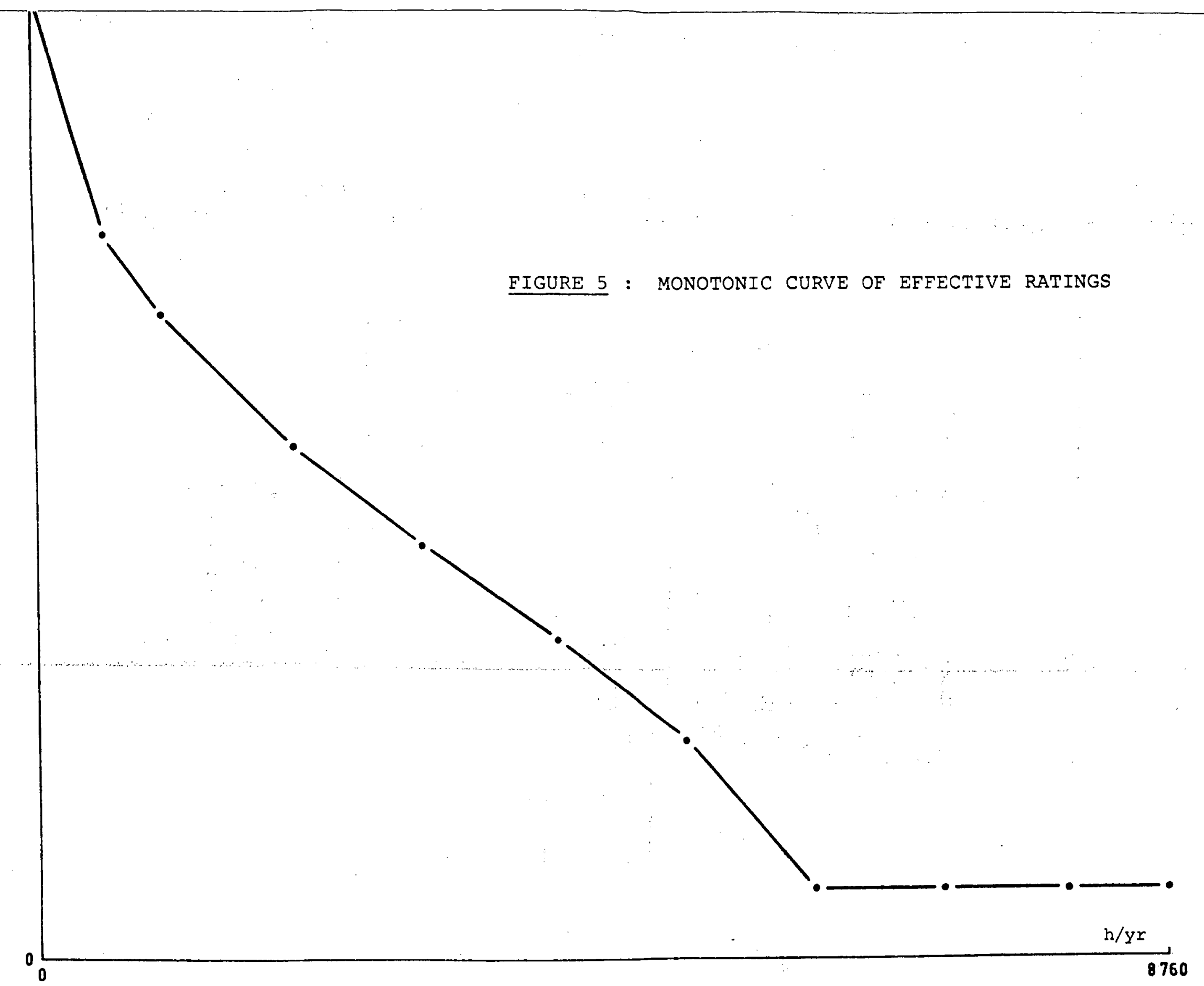




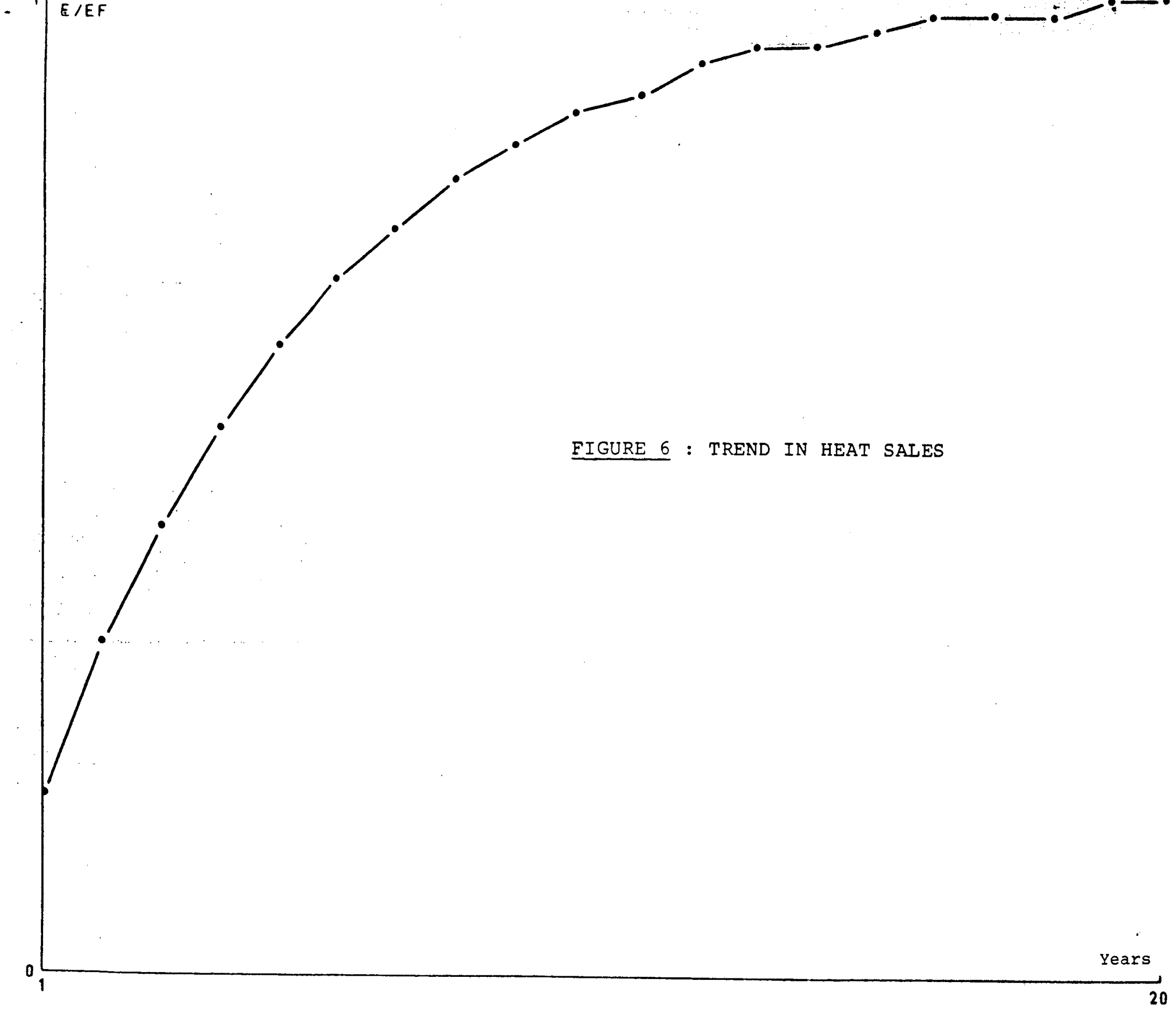




\section{DISTRIBUTION}

HEAD PRESSURE (mm. CE) =

230000 .

TEMPERATURE RANGE (C) $=$

40 .

TOTAL OUTLET LENGTH OF NETWORK $(\mathrm{m})=59698$.

MAXIMUM POWER TAKEOFF $(\mathrm{Th} / \mathrm{h})=381010$.

LINEAR "THERMAL DENSTTY" $(\mathrm{Th} / \mathrm{m} / \mathrm{km})=6382$.

\begin{tabular}{|c|c|c|c|c|c|c|}
\hline $\begin{array}{l}\text { NODE } \\
\text { NO }\end{array}$ & $\begin{array}{l}\text { EQUIVALENT } \\
\text { FLOW RATE } \\
\mathrm{m}^{3} / \mathrm{h} \\
\end{array}$ & $\begin{array}{c}\text { TAKEOFF } \\
\text { FLOW } \\
\mathrm{m}^{3} / \mathrm{h} \\
\end{array}$ & $\begin{array}{c}\text { SPEED } \\
\mathrm{m} / \mathrm{s}\end{array}$ & $\begin{array}{l}\text { HEAD LOS } \\
\text { MM. CE: }\end{array}$ & $\begin{array}{c}\text { THERORETICAL } \\
\text { DIAMETER } \\
\mathrm{mm} \\
\end{array}$ & $\begin{array}{c}\text { NOMINAL } \\
\text { DIAMETER } \\
\mathrm{mm} \\
\end{array}$ \\
\hline 1 & 4143.76 & 199.27 & 2.61 & 19458 & 744 . & 750 \\
\hline 2 & .238 .17 & 99.71 & 2.34 & 8395 & 684. & 700 \\
\hline 3 & 355.66 & 291.32 & $2.0 \cdot 1$ & 50924 & 233 & 250 \\
\hline 4 & 233.35 & 68.93 & $2 .(1)$ & 308600 & . 16 & 175 \\
\hline 5 & 2878.70 & 191.61 & 2.083 & 12750 & 65. & 700 \\
\hline 6 & 126.10 & 218.42 & 1.98 & 61724. & 142. & 150 \\
\hline 7 & 35.37 & 61.27 & 1.25 & 10347 & 89. & 100 \\
\hline 8 & 77.46 & 134.17 & 1.22 & 14307 & 143. & 150. \\
\hline 9 & 59.78 & 103.53 & 1.75 & 30999. & 100 & 110 \\
\hline 10 & 53.06 & 91.90 & 1.88 & 34920 & 93. & 100 \\
\hline 11 & 1535.55 & 84.53 & 2.17 & 8607 & 497. & 500. \\
\hline 12 & 1135.90 & 141.83 & 1.98 & 13383. & 443 & 450 \\
\hline 13 & 1370.78 & 49.78 & 1.94 & 4040 & 480. & 500 \\
\hline 14 & 55.35 & 95.88 & 1.96 & 39645 . & 94. & 100 \\
\hline 15 & 92.94 & 160.98 & 1.80 & 41847 & 131. & 135. \\
\hline 16 & 470.25 & 667.02 & 1.36 & 37900 & 335. & 350 \\
\hline 17 & 73.04 & 126.51 & 1.65 & 29847 & 113. & 125. \\
\hline 18 & 1188.49 & 122.68 & 1.68 & 7483 & 400 & 500. \\
\hline 19 & 57.56 & 99.71 & 2.04 & 44587 & 98. & 100 \\
\hline 20 & 28.74 & 49.78 & 0.56 & 1238 & 128. & 135. \\
\hline 21 & 30.95 & 53.61 & 0.60 & 1546. & 134. & 135. \\
\hline 22 & 113.98 & 197.43 & 1.32 & 21090 & 156. & 175. \\
\hline 23 & 740.03 & 237.70 & 1.64 & 17156. & 393. & 400 \\
\hline 24 & 44.22 & 76.59 & 1.56 & 20208 & 88 & 100 \\
\hline 25 & 537.49 & 57.44 & 1.19 & 2187 & 356. & 400 \\
\hline 26 & 26.53 & 45.75 & 1.47 & 13321 & 74 . & 80 . \\
\hline 27 & 143.79 & 249.05 & 1.00 & 12051 . & 215. & 225 . \\
\hline 28 & 148.29 & 256.85 & 1.04 & 13219 & 219. & 225 . \\
\hline
\end{tabular}

HEAT LOSSES $(t h / h)=$

PERCENTAGE OF HEAT LOSSES IN WINTER = AVERAGE PERCENTAGE OF HEAT LOSSES = DURATION OF WORK (PIPING) (YEARS) = DURATION OF CONNECTION (WORK YEARS) = NOMINAL PUMPING CAPACITY $(\mathrm{kW})=$

MAXIMUM HEAT RATING AT NETWORK OUTLET (th/h) TOTALDISCOUNTED INVESTMENT (m FF) =

13834 . 3.5 . 11.3

$$
2
$$

10

3666 .

394843 .

189.6 


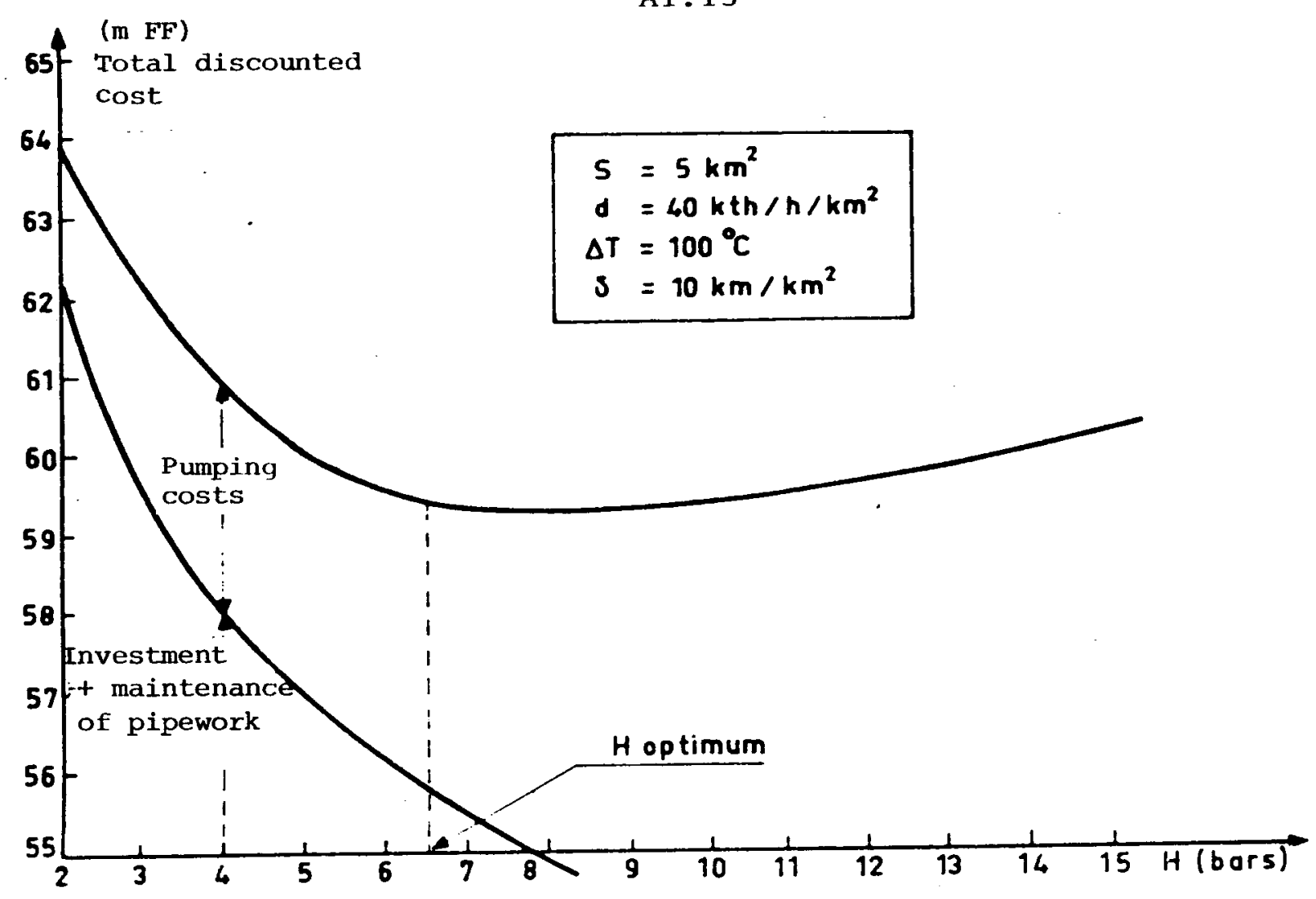

FIGURE 8 : INFLUENCE OF PREMISSIBLE LOSS OF HEAD ON THE TOTAL DISCOUNDTED COST OF DISTRIBUTION

$S$ = surface covered

$\mathrm{d}=$ "thermal density" of appliances connected

$\Delta T=$ effective temperature range

$\delta=$ "network density" $\frac{\text { length }}{\text { surface }}$

$\mathrm{H}=$ network head loss

Specific network

investment

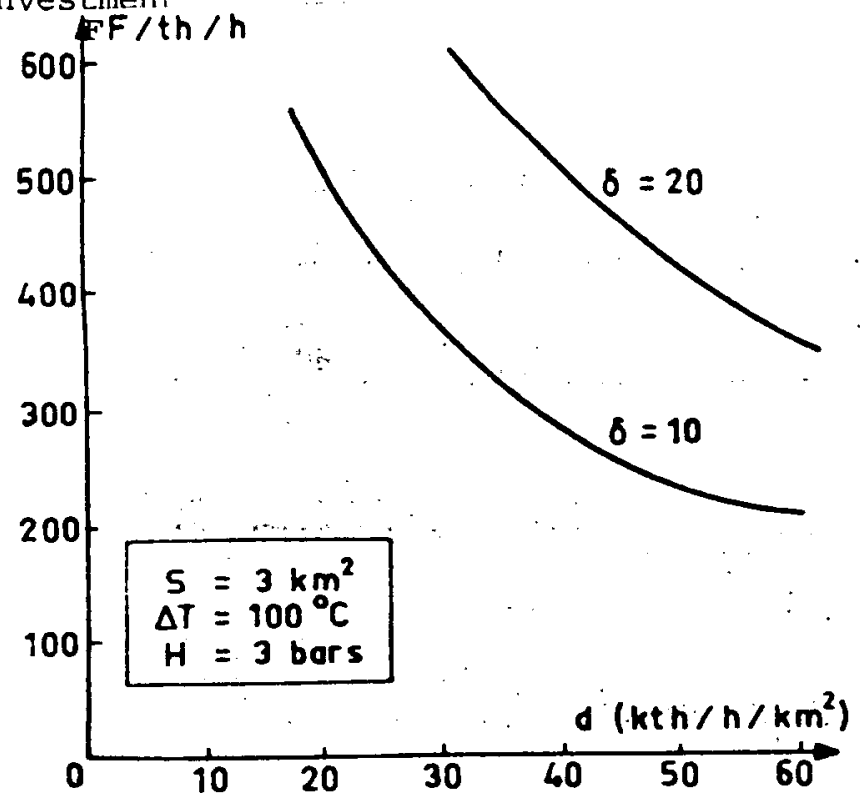

Specific network

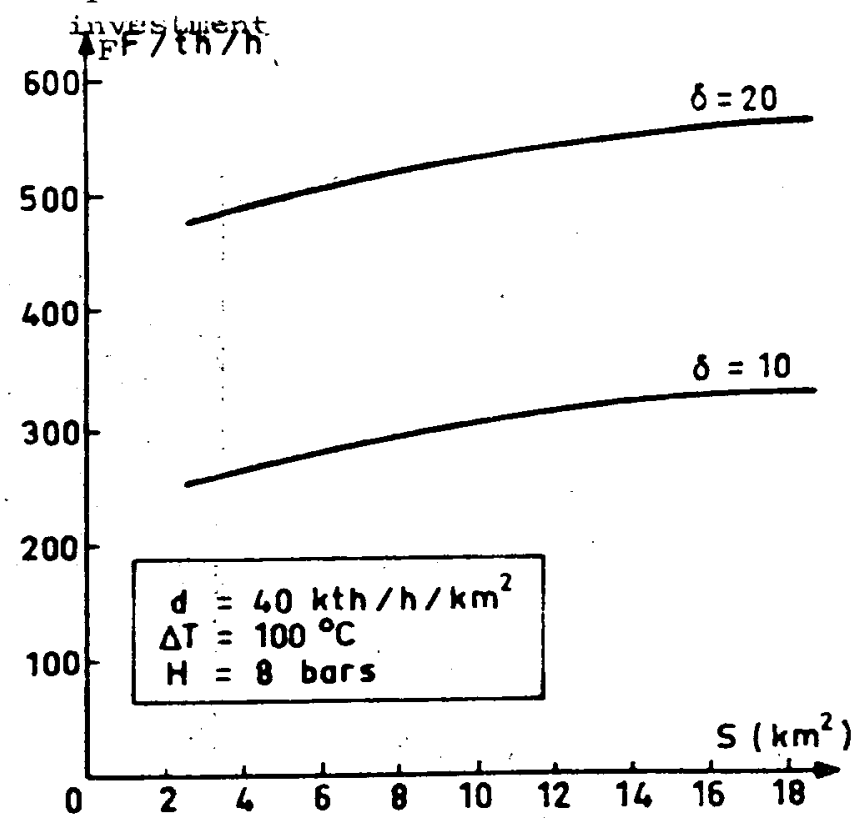

FIGURE 9 : INFLUENCE OF "THERMAL FIGURE 10 : INFLUENCE OF AREA DENSITY" COVERED. 


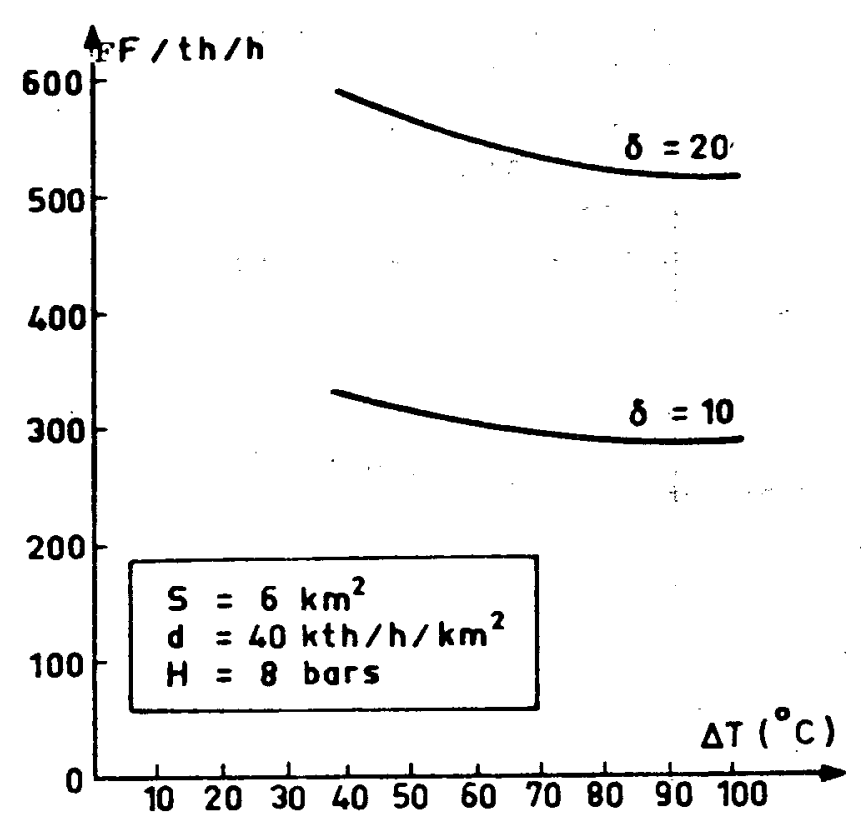

FIGURE 11 : INFLUENCE OF TEMPERATURE: RANGE (OUTLET-INLET)

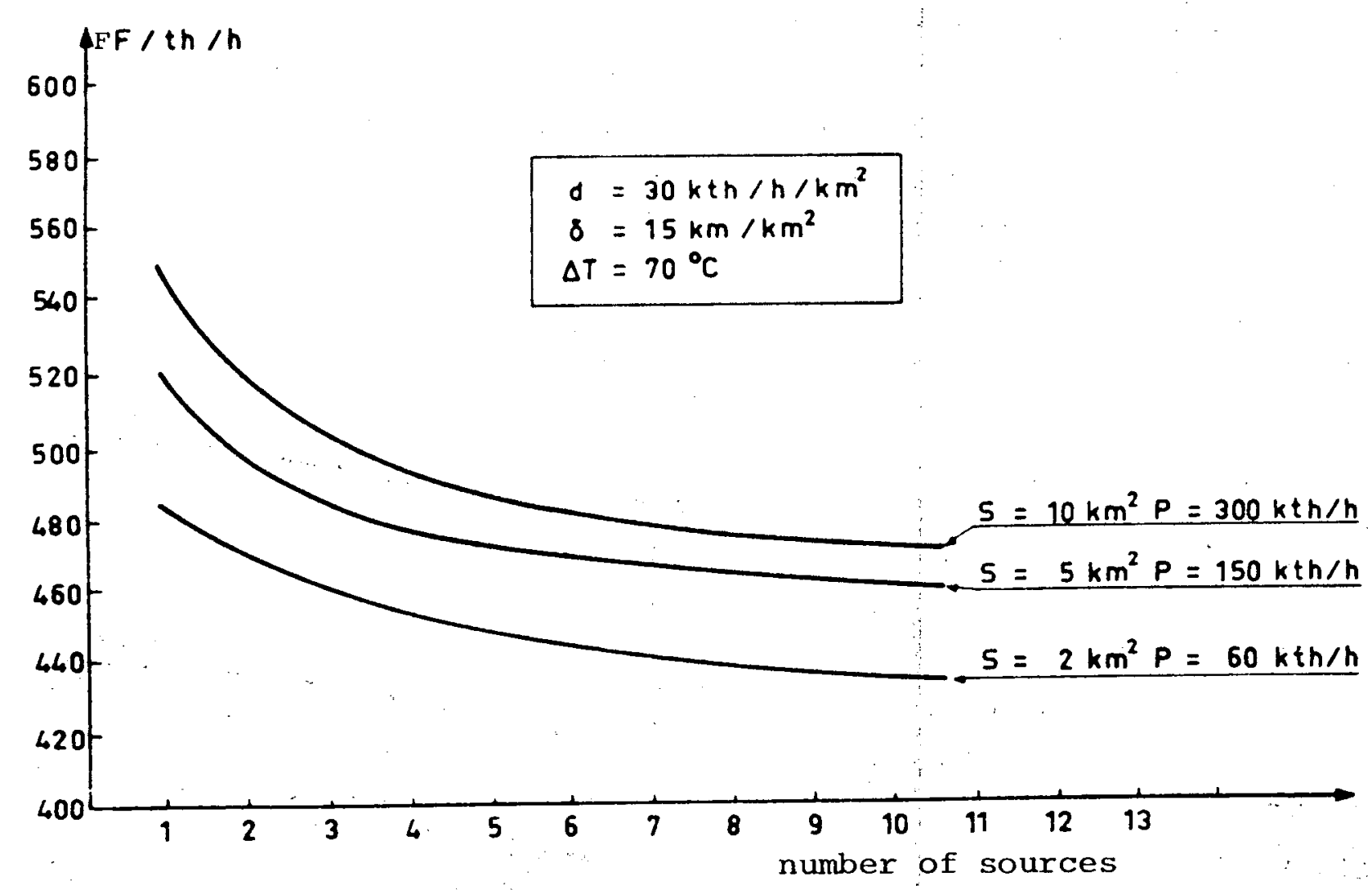

FIGURE $12 \therefore$ INFLUENCE OF NUMBER OF SOURCES ON SPECIFIC INVESTMENT 